\title{
Neuropathology of suicide: recent findings and future directions
}

\author{
Pierre-Eric Lutz MD PhD, ${ }^{1}$ Naguib Mechawar PhD, ${ }^{1,2}$ and Gustavo Turecki MD PhD ${ }^{1,2^{*}}$ \\ ${ }^{1}$ McGill Group for Suicide Studies \\ ${ }^{2}$ Department of Psychiatry, McGill University \\ Douglas Mental Health University Institute \\ 6875 LaSalle Blvd, Montreal, QC H4H 1R3, Canada \\ Correspondence to: \\ Gustavo Turecki \\ McGill Group for Suicide Studies \\ Department of Psychiatry, McGill University \\ Douglas Mental Health University Institute \\ 6875 LaSalle Blvd, Montreal, QC, H4H 1R3, Canada \\ (514) 761-6131 ext. 3366 \\ gustavo.turecki@mcgill.ca
}

\begin{abstract}
Suicide is a major public health concern and a leading cause of death in most societies. Suicidal behaviour is complex and heterogeneous, likely resulting from several causes. It associates with multiple factors, including psychopathology, personality traits, early-life adversity and stressful life events, among others. Over the last decades, studies in fields ranging from neuroanatomy, genetics, and molecular psychiatry have led to a model whereby behavioural dysregulation, including suicidal behaviour, develops as a function of biological adaptations in key brain systems. More recently, the unravelling of the unique epigenetic processes that occur in the brain has opened promising avenues in suicide research. The present review explores the various facets of the current knowledge on suicidality, and discusses how the rapidly evolving field of neurobehavioural epigenetics may fuel our ability to understand, and potentially prevent, suicidal behaviour.
\end{abstract}

\section{Manuscript length}

Length: 8,089 words

Abstract: 135 words

Figures: 3

Tables: 2

Number of references: 375 


\section{General model of suicide risk}

The last decade has seen intensified research on suicide and suicidal behaviours (SB). Despite an increased understanding of the factors at play, suicide continues to place a great burden on all societies. Global prevalence of suicide continues to be high, with an annual global age-standardized suicide rate of 11.4 per 100,000 people, which translates to approximately 800,000 people dying by suicide every year. ${ }^{1}$ This number does not take into account the other forms of suicidality, such as suicide attempts (SA) and suicidal ideation (SI) (12-month prevalence approximately 25 and 175 times the prevalence of suicide fatalities, respectively ${ }^{2}$ ). While the extent and characteristics of the relationship between these phenotypes and suicide are not entirely established, they also represent a burden and public health concern in their own right. Up to one third of individuals with SI have a SA within one year; individuals who have had a SA have a $16.3 \%$ risk of repeated SA and $1.6 \%$ risk of suicide within the year. ${ }^{3}$ Anxiety disorders, impulse-control disorders, mood disorders, and alcohol abuse or dependence may partially facilitate the transition from SI to SA, ${ }^{4,5}$ and axis I psychiatric disorders are present in the vast majority of suicide fatalities at the moment of death, as determined by medical records and/or psychological autopsy reports. ${ }^{6,7}$ Psychiatric disorders are thus key proximal factors in building suicide risk, ${ }^{5}$ with various disease characteristics being associated with increased risk, but particularly depressed mood. For example, in patients with schizophrenia (SCZ), suicide risk is associated with depressive features and insight. ${ }^{8}$ In bipolar disorder (BD), risk of suicide is heightened during mixed episodes and major depressive episodes, as well as during the early stages of illness, ${ }^{9}$ while in the case of major depressive disorder (MDD), the number, duration, and intensity of major depressive episodes are determinants of suicide risk. ${ }^{10-12}$ Depression therefore represents a major confounder in all suicide studies, particularly in biological analyses of SBs, where discrete disease-related contributions to suicide risk have not been clearly identified, and the majority of studies include samples derived from individuals with depression and SB, often without non-depressed suicide controls.

The recent call to action by the World Health Organization $^{1}$ has given additional momentum to the field of suicide research, and multiple models have been proposed to describe the events leading to a suicide. The relative contributions of distal versus proximal factors, as well as the strength of association of individual factors, such as early-life adversity (ELA), ${ }^{13,14}$ and mediating factors, such as anxious or impulsive personality traits, ${ }^{15,16}$ are described differently depending on the model favoured. ${ }^{17-21}$ Despite their differences, these models have many commonalities, highlighting the complex, multifactorial nature of suicide and SB. ${ }^{5,21}$ (Figure 1) A key consideration in explaining the impact of psychological traits and experience on suicidality is that biological changes underpin behavioural changes. ${ }^{22}$ Efforts to understand the biological factors that contribute to suicide focus on describing the processes involved in eliciting behavioural change and identifying potential targets to alter unhealthy behaviours. An important research avenue has been the search for clinically-applicable biomarkers for suicide, as these would allow healthcare practitioners to specifically address SB in those most at risk. ${ }^{23}$ New techniques and more accessible services have driven neurobiological research in suicide in fields ranging from neuroanatomical changes linked to suicide or heightened suicide risk to genetic bases for suicide, and genomic and protein interactions contributing to SB. 


\section{Genetic contributors to suicide risk}

Most accepted models of suicide risk distinguish between predisposing (distal, or diathesis) factors and precipitating (proximal, or stress) factors. ${ }^{21}$ The idea that individuals may be predisposed to suicide stems in part from the observation of familial aggregation of SB, which has been documented since the $1980 \mathrm{~s}^{24}$ and which has been observed in a number of large cohorts including a Swedish national registry-based study $(83,951 \text { probands })^{25}$ and twin and adoption studies pointing to a heritability of SB between $30-50 \% .{ }^{26-28}$ Offspring of probands having attempted suicide are also at a nearly 5-fold higher risk of attempting suicide themselves. ${ }^{29}$ Although many other psychiatric conditions associated with SB are also heritable, severe SBs (suicide and SAs) appear to be transmitted independently of Axis I and Axis II disease. ${ }^{15,16,30,31}$ When heritability is corrected for transmission of psychiatric disorders, specific heritability is between $17-36 \% .{ }^{26}$ Such evidence for family clustering of SB, even after correction for transmission of other psychiatric conditions, suggests there is a genetic predisposition to SB and has fuelled research into genes associated with SB.

Identifying one or several genes or gene variants that may increase predisposition to SBs has been a challenging task. Over 200 genes have been reported as being associated with SA or suicide death, with the rate of discovery of new SB candidate genes increasing exponentially in the last decade. ${ }^{32}$ Preexisting knowledge of biological systems likely to be associated with SBs, such as rate of serotonin synthesis, decreased serotonergic neurotransmission, and neurotrophic factors, have driven extensive candidate-gene studies. ${ }^{33-36}$ Results from these studies have generally not been consistent, leading to decreased enthusiasm for genetic variation studies focusing on single genes over the last decade in favour of genome-wide association studies (GWAS), which use a less-biased, gene-discovery based approach. ${ }^{37}$ Despite major technical developments in our capacity to effectively and quickly investigate the genome, a major challenge in GWAS is the tremendous number of samples required to detect genetic variants that account for a very small proportion of the total phenotypic variance. As a result, genome-wide significance of GWAS studies of SB has remained elusive. The existing GWAS studies that have directly or indirectly examined $\mathrm{SB}^{38-49}$ have nonetheless pointed to a number of variants that, while not achieving genome-wide significance, may be interesting targets for future studies of SB. (Supplementary Table 1)

Due to the relative rarity of death by suicide, suicide was not often used as a phenotype in GWAS studies of SB. The first of two studies using suicide as a primary phenotype ${ }^{38}$ compared single nucleotide polymorphisms (SNPs) in 68 suicides vs. 31 psychiatrically healthy controls, and identified suggestive evidence for SNPs in or around 19 genes. Seven of these genes were differentially expressed in brain tissue of a partially overlapping sample of 18 suicides and 21 controls. ${ }^{38}$ The second study investigated SNPs in a larger sample comprising both completed suicides and live subjects with SA ( $N=577)$ compared with psychiatric or healthy controls without a history of $S A(N=1,233) .{ }^{39}$ Although no result reached genome-wide significance, seven of the nine suggestive SNPs observed in the analysis comparing suicides versus individuals without $S B$ ( $N=317$ Cases vs. 1,233 Controls) mapped to the TBX20 gene, which among other functions is a transcription factor with identified roles in the CNS. ${ }^{39,50}$ Among the other GWAS studies published, SAs and/or SI were used as phenotypes. Among the numerous SNPs identified through these studies, 15 SNPs have shown evidence of at least a trend 
toward significance between case and control groups ( $P$-values $<10^{-6}$; see shaded cells in Supplementary Table 1). Of note, only SNPs in or near three genes appear to have reached genome-wide significance, one located near the $A C P 1$ gene, ${ }^{45}$ one located within $A B I 3 B P,{ }^{41}$ and one located within $P A P L N,{ }^{40}$ and all of these have been described to regulate the extracellular matrix and collagen-binding. Among the other hits that did not reach genome-wide significance, genes had ascribed functions in cellular assembly and organization, nervous system development and function, cell death and survival, immunological disease, infectious disease, and inflammatory response. ${ }^{39}$

An outstanding concern regarding the results from GWAS studies is the lack of reproducibility of results. To a large degree this may be explained by the generally small samples investigated by GWAS studies of SB. Recently, attempts have been made to describe polygene effects, ${ }^{46,48}$ and a recent study identified 750 genes linked to neurodevelopment that appeared to selectively drive SBs, independently from schizophrenia or MDD diagnosis. ${ }^{48}$ Analysis of genes associated with psychopathologies and SB identified several pathways of interest (cell adhesion/migration, small GTPase and receptor tyrosine kinase signalling) and identified genes that have been independently associated with SBs, such as BDNF and NTRK2, among others. If replicated, these results could support using polygenic analyses to bridge results from GWAS studies with other studies that have already provided suggestive evidence of genetic associations with SBs.

Collectively, GWAS studies show that despite a great deal of enthusiasm and the potential to uncover novel genetic contributors to SBs, as observed for other psychiatric phenotypes, individual gene variants are likely to account only for a very small proportion of the total phenotypic variability. Other factors, such as the environment, behavioural traits, life trajectories, and coping mechanisms, are essential regulators of suicide risk, and likely to account for more sizeable effects. ${ }^{5}$

\section{Functional genomics of biological circuits implicated in suicide}

Our understanding of how the genome is regulated, in particular through a variety of epigenetic mechanisms, has contributed to one of the most meaningful changes to the neuroscience landscape in the past 15 years. ${ }^{51}$ The investigation of biological processes underlying SB has greatly benefitted from the study of these mechanisms (Figure 2), which allow for a fine-tuning of biological responses, and offer an intuitive explanation for the impact of experiences into altered behavioural phenotypes. Adjusting physiological and behavioural responses to environmental cues is essential for adaptation, but in cases of childhood maltreatment or abuse, such adaptations can have detrimental effects. ${ }^{52,53}$ Early-life adversity (ELA), defined as neglect or physical or sexual abuse during childhood, has profound and longlasting effects on the development of psychological and cognitive traits associated with increased risk of suicidality. ${ }^{54,55}$ Further, a significant proportion of individuals exhibiting SB have a history of ELA. ${ }^{52,56-58}$ Biological mechanisms for the translation of such traumatic experiences into behaviour have been proposed to be principally regulated by altered DNA methylation and histone modifications. ${ }^{59}$ Such regulation of expression and function of molecules has the potential to drive pathological processes, partly because they change over the life course. Global study of methylation in brain tissues indicates 
that suicide is associated with widespread changes in methylation patterns of neurotrophic and neuroprotective factors in the hippocampus and prefrontal cortex.${ }^{60,61}$ Continued technological improvements have made sequencing approaches more affordable and are bringing high-resolution whole-methylome analysis within reach. ${ }^{62}$

Mechanisms that affect the architecture and expression of the genome as a function of life experiences differ among brain regions and cell types. Accordingly, understanding suicide neurobiology requires integrating brain region- and cell type-specific processes into global patterns of brain activity dysregulation. Structural and functional alterations affecting depressed patients mainly derive from neuroimaging studies, and histological investigations of postmortem brain samples. These studies have provided evidence that some brain cells and circuits are selectively associated with suicide. In the following sections, we aim at articulating changes in genomic and epigenomic functions within brain regions most consistently implicated in mood disorders and suicide, most notably: brainstem monoaminergic systems, the prefrontal cortex (PFC), the anterior cingulate cortex (ACC), the amygdala, and the hippocampus (Figure 3 ).

\section{Neurotransmitters and neuromodulators}

\section{New findings on monoaminergic systems, hippocampal function and suicide}

The entire brain receives monoaminergic innervation from 5-HT and noradrenergic neurons located in raphe nuclei and the locus coeruleus (LC), respectively. 5-HT neurons have long been implicated in depressive disorders and suicide, ${ }^{63}$ with substantial evidence suggesting impaired serotonergic function, ${ }^{64-66}$ as summarized in recent exhaustive reviews. ${ }^{23,35,67,68}$ Among other findings, studies found that depressed suicide completers show in dorsal raphe nucleus decreased levels of the serotonin metabolite, 5-HIAA, ${ }^{35}$ as well as more $5-\mathrm{HT}$ neurons ${ }^{19,69}$ and increased mRNA expression and protein levels of tryptophan hydroxylase (TPH, the rate-limiting enzyme in the synthesis of 5- $\mathrm{HT}^{70-73}$ ). Upregulation of TPH activity and increased numbers of 5-HT neurons, have been interpreted as mechanisms compensating for an overall reduction in 5-HT transmission, a finding that has been supported by imaging studies. ${ }^{74,75}$ In addition to brain tissue, several studies have shown that low levels of 5-HIAA can also be observed in the CSF in the context of SB. ${ }^{76}$

Due to their high rate of co-occurrence, a major obstacle has been isolating factors specifically responsible for SB, rather than depression. ${ }^{13}$ Some studies have successfully distinguished changes associated with depression from those associated with suicide, identifying small changes in serotonin transporter (SERT) and receptor expression $\left(5-\mathrm{HT}_{1 \mathrm{~A}}\right)$, as well as indications of serotonin genotypes and expression patterns that may be specifically linked to suicidality. ${ }^{13,74,77,78}$ The characterization of personality traits linked to suicide has shown that impulsive/aggressive phonotypes may be associated with altered serotonin levels, especially in the context of ELA. ${ }^{79}$ Recently, studies have pointed towards epitranscriptomic dysregulation of serotonin signaling in suicide and SB (see below, and ${ }^{80,81}$ ). In the future, researchers will face the challenge of exploring the psychopathological significance of complex interactions between multiple serotonin and other monoamine receptor types (e.g. 5- $\mathrm{HT}_{4}, 5-\mathrm{HT}_{1 \mathrm{~B}}, 5-$ 
$\left.\mathrm{HT}_{2 \mathrm{~B}}\right)$, and associated adaptor proteins ( $\left.\mathrm{p} 11, \mathrm{~S} 100 \alpha\right)$, that are currently emerging from animal research. ${ }^{82-86}$

Deficits in noradrenergic transmission have similarly been recognized in depression for decades ${ }^{87}$. In analogy with aforementioned findings regarding 5-HT neurochemistry, increased expression of tyrosine hydroxylase, the rate-limiting enzyme in the synthesis of catecholamines, including noradrenaline, has been measured in postmortem LC samples from depressed patients ${ }^{88,89}$ (see also $\left.{ }^{90}\right)$. Although one report has indicated significant reductions in the total number and average density of pigmented LC neurons in the left side of the brainstem in suicide completers, ${ }^{91}$ most morphological studies of the LC have found no differences between MDD and control subjects. ${ }^{90,92,93}$ Recent studies using laser capture microdissection to analyze cell-specific patterns of expression in depressed suicides showed decreased expression of glutamate transporters by LC astrocytes, ${ }^{94}$ as well as upregulated expression of NMDA receptor subunits by LC neurons. As proposed by the authors, this increased glutamatergic activity in the LC may account for the fast-acting antidepressant properties of NMDA antagonists. ${ }^{95}$

At the neuroanatomical level, the role of monoamines in depression and suicide has been largely investigated in the context of its relationship to hippocampal neurogenesis, a major substrate of mood regulation and antidepressants mode of action. Stockmeier et al. ${ }^{96}$ have reported increases in the mean densities of pyramidal neurons and glial cells in cornu ammonis (CA) regions and in the DG granule cell layer, with accompanying reductions in the mean soma size of these cells in samples from MDD subjects versus controls. In MDD patients, hippocampal volume is reduced, ${ }^{97}$ and this phenomenon can be partly counteracted by antidepressant treatment. ${ }^{98}$ Hippocampal shrinkage has been hypothesized to result in part from decreased adult neurogenesis in the dentate gyrus (DG). Abundant preclinical research has shown that adult animals exposed to chronic stress and displaying depressive-like behaviours have decreased hippocampal neurogenesis. ${ }^{99}$ Inversely, $\mathrm{ECS}^{100}$ a model of $E C T$, or conventional antidepressant drugs such as selective serotonin reuptake inhibitors (SSRIs), potently increase neurogenesis in the DG. ${ }^{101}$ In turn, this improves stress regulation ${ }^{102}$ and is sufficient to reduce anxiety- and depressive-like behaviours in mice. ${ }^{103}$ Postmortem studies have also suggested that progenitor proliferation is increased by antidepressant treatment, while the expression of proliferative markers in DG samples was similar between untreated depressed patients and controls. ${ }^{104,105}$ The same group reported significant reductions in DG granule cell numbers in anterior (but not posterior) hippocampal samples of untreated MDD patients compared to matched controls. ${ }^{106}$ In the absence of changes in numbers of progenitor cells, these results suggest depression-associated impairments in granule cell neuron maturation or survival, and support the notion that decreased adult hippocampal neurogenesis contributes to hippocampal volume loss in depression.

\section{The GABAergic and glutamatergic systems}

Transcriptomic studies designed to identify dysregulated genes in individuals who died by suicide have repeatedly pointed towards disrupted glutamatergic and GABA-ergic pathways in several brain regions, ${ }^{62,107-113}$ particularly in the PFC and the ACC. These two brain regions have been consistently 
implicated in MDD by spectroscopic, ${ }^{114-116}$ structural, ${ }^{117-119}$ and functional studies. ${ }^{120-122}$ The PFC is essential for executive function, ${ }^{123,124}$ while the ACC plays important roles in stress responses ${ }^{125}$ and the integration of cognitive activity with affective experience. Ultimately, changes affecting excitatory and inhibitory transmission in these structures are thought to underlie abnormalities documented in neuroimaging (e.g. hypoactivity ${ }^{126-128}$ and loss of grey matter volume ${ }^{129}$ in the PFC), and neuroanatomical (e.g. reduction in third-order branching of basilar dendrites of layer VI pyramidal neurons in $\mathrm{dACC}^{130}$ ) studies.

In microarray studies, GABA type $A[G A B A(A)]$ receptors were globally found to be upregulated in suicides with depression, but not those without depression. ${ }^{111,112}$ However, a study comparing $\operatorname{GABA}(A)$ across multiple brain regions from MDD suicides, found decreased $G A B A(A) \alpha$ and $\delta$ subunits in the majority of brain areas investigated, ${ }^{131}$ and a recent study identified a transcript for the GABA(A) receptor $\gamma 2$ subunit (GABRG2) that was downregulated in postmortem MDD-suicide PFC tissue. ${ }^{132}$ Of interest, $\mathrm{GABA}(\mathrm{A})$ receptor expression may be differentially regulated through altered DNA methylation levels and downregulated DNA methyltransferase (DNMT) in the frontopolar cortex of suicide brains. ${ }^{133}$ Follow-up studies focusing on these receptors are required to better interpret their relationship with SB.

In the glutamate pathway, a number of proteins are found to be associated with suicidal events, including the NMDA receptor GRIN2B subunit, which was found to be associated with SA in a GWAS, ${ }^{48}$ the AMPA receptor GRIA3 and the kainate receptor GRIK2 subunits, which were associated with treatment-emergent suicidal ideation (TESI) in a GWAS, ${ }^{40}$ the glutamate transporters SLC1A2 and SLC1A3, and the glutamate-ammonia ligase (GLUL), which were associated with MDD-suicide in postmortem analyses of dorsolateral PFC and ACC tissue. ${ }^{111,112}$ In studies distinguishing between MDD and MDD-suicide, GRIN2B, GRIK3 and GRM2 were specifically upregulated in the dorsolateral PFC of suicides, ${ }^{134}$ while astrocytic components of the glutamate pathway in this same brain region, including GLUL, were downregulated. ${ }^{135}$ In the ACC, neuronal components of the glutamate pathway were upregulated. ${ }^{135}$

A drug targeting the glutamate pathway, ketamine, has recently drawn attention for its ability to rapidly treat depressive symptoms. ${ }^{136-138}$ It also holds great promise as a potential anti-suicidal drug, rapidly decreasing SI among patients with treatment-resistant depression and SI. ${ }^{139-141}$ Ketamine acts rapidly (within a few hours) and has potentially long-lasting effects (up to 3 months post-infusion). ${ }^{141}$ However, its mechanism of action is still unclear, with suggestions that it may inhibit astrocyte secretion of BDNF, ${ }^{142}$ upregulate insulin-like growth factor 2 in the hippocampus, ${ }^{143}$ or contribute to maintaining healthy levels AMPA and NMDA receptor expression. ${ }^{144}$ Although ketamine is an NMDA antagonist, recent studies in rodents show that its antidepressant-like effects appear to be mediated by an activation of AMPA signalling. ${ }^{145}$ Activation of AMPA receptors by ketamine may occur through inhibition of glycogen synthase kinase-3 (GSK3), ${ }^{146}$ which could be partially mediated by the ketamineinduced upregulation of mouse microRNA clusters miR448-3p and miR764-5p, miR1264-3p, miR1298-5p and miR1912-3p, all of which are linked to the serotonergic (5HT)-2C receptor (5HTR2C). ${ }^{147}$ Ketamine may therefore act in part through microRNA modulation, but the impact of such an effect on SB remains to be determined. 
Finally, it is worth noting that overall modifications of the excitatory/inhibition imbalance in the context of depression and suicide may also stem from changes in cellular phenotypes, a form of cellular plasticity that has been recently documented in the amygdala. The amygdala is important in emotional processing and is involved in regulating many behaviours, such as fear and aggression. ${ }^{148}$ Neuroimaging studies have associated MDD with increases in amygdalar blood flow and glucose metabolism, ${ }^{126}$ as well as altered volume. ${ }^{149,150}$ Postmortem studies have reported a greater basolateral amygdala (BLA) volume associated with an increase in neurovascular cells in MDD. ${ }^{151}$ Maheu and colleagues also published evidence that amygdalar neuroplasticity appears to occur in depression, but not in suicide. ${ }^{152}$ Proteins associated with neuroplasticity, such as doublecortin (DCX) and PSA-NCAM, were upregulated in BLA samples from depressed patients having died naturally or of accidental causes, but not in depressed suicides. ${ }^{152}$ The inability to upregulate amygdalar plasticity may therefore contribute to suicide. In agreement with this, numbers of somatostatin neurons are decreased in the amygdala of women with MDD, possibly attributable to a change in phenotype rather than to cell loss. ${ }^{153}$

\section{Glial and immunological contributors to suicide risk}

While glial cells account for the majority of cells in the human brain, their potential association with suicide has been investigated relatively recently. Overall, findings point towards reductions in macroglial cell (mainly astrocytes and oligodendrocytes) densities ${ }^{109,154,155}$ or soma size, ${ }^{156}$ while microglial cells appear to show enhanced activation and recruitment. ${ }^{157}$ In the subgenual ACC and in the amygdala, an overall glia reduction was initially documented. ${ }^{158}$ Comparable findings in the dorsal ACC (dACC) were subsequently made by some investigators but not by others. ${ }^{159}$ The latter study found similar glial densities between samples from depressed suicides and controls, but significantly increased density in samples from individuals with co-morbid alcohol dependence. ${ }^{159}$

In the amygdala, reductions in overall glial cell densities have been found ${ }^{160}$ (see also ${ }^{151}$ ), an observation subsequently attributed to lower numbers of oligodendrocytes. ${ }^{161}$ It is tempting to speculate that this phenomenon is related to the altered glial cell line-derived neurotrophic factor (GDNF) signalling recently evidenced in the BLA of depressed suicides, ${ }^{162}$ as this neurotrophic factor has been shown to be expressed by mature oligodendrocytes. ${ }^{163}$

Astrocytes are polyfunctional glial cells whose roles include supporting neurons, regulating the supply of nutrients, metabolites and growth factors, and availability of neurotransmitters and ions, as well as maintaining the blood-brain barrier and playing a key role in immunity. ${ }^{164,165}$ In studies using animal models of mood disorders, astrocyte and glial functions are disrupted, particularly in relation to glutamatergic signalling. ${ }^{166,167}$ Further to this, in suicide, astrocyte morphology and function appear to be altered in discrete brain regions of depressed suicides. In the PFC ${ }^{168,169}$ and dACC white matter, hypertrophic astrocytes, ${ }^{170}$ as well as increased proportions of priming and perivascular macrophages, ${ }^{168}$ have been described, all suggestive of low-level neuroinflammation in these regions (reviewed in $\left.{ }^{171}\right) .{ }^{170,172,173}$ A microarray expression study conducted in postmortem suicide brains identified decreased mRNA expression of the astrocyte connexins $(C x) 30$ and $43,{ }^{173}$ which are key factors in maintaining the blood-brain barrier. ${ }^{174}$ Subsequent analysis of histone methylation profiles of astrocyte-related genes 
confirmed that $\mathrm{C} \times 30$ and $\mathrm{C} \times 43$ are downregulated and provided evidence of epigenetic control of connexin genes. ${ }^{134}$ Some recent evidence suggests that the permeability of the blood-brain barrier may be increased in individuals having recently attempted suicide, ${ }^{175}$ which also suggests that inflammatory processes occur in the brains of suicide attempters. Transcriptomic analyses of the PFC of depressed suicides revealed that a number of astrocytic genes are downregulated compared to healthy controls, with the most significant alterations in aldehyde dehydrogenase 1 family member L1 (ALDH1L1) and glial fibrillary acidic protein (GFAP). ${ }^{62}$ Similar downregulation of GFAP expression has also been identified in the PFC in animal models (mRNA) ${ }^{166}$ and in several subcortical regions of depressed suicides (mRNA and protein). ${ }^{94,172}$ Finally, decreased density of glial fibrillary acidic protein (GFAP)-immunolabelled astrocytes was reported in the DG of women, but not men, with depression. ${ }^{176}$ Of note, the same parameter measured in $\mathrm{CA} 2 / 3$ was reported to be inversely correlated with the duration of depression in suicides. ${ }^{177}$

Evidence has been accumulating to support a relationship between inflammation and depressive states. ${ }^{178-180}$ High levels of comorbidity are observed in the clinic between inflammatory autoimmune diseases and depression, ${ }^{181,182}$ and a substantial proportion of patients receiving cytokine therapy develop depression. ${ }^{183,184}$ Conversely, depressive states associate with increased levels of proinflammatory cytokines, including tumour necrosis factor, interleukin- 6 (IL-6), ${ }^{185} \mathrm{IL}-2, \mathrm{IL}-8,{ }^{186}$ and IL$1 \beta .{ }^{187,188}$ Available evidence further suggests a specific association between those inflammatory markers and SB, with results showing increased levels of IL- 6 and decreased levels of IL- 2 in patients with SB, ${ }^{189}$ as well as decreased levels of vascular endothelial growth factor (VEGF) ${ }^{190}$ and changes in levels of quinolinic acid or kynurenic acid. ${ }^{181,191,192}$

A related line of evidence comes from the proposed role of the brain-tropic parasite, Toxoplasma gondii, in raising suicide risk. ${ }^{193,194}$ In a sample of 45,745 women systematically tested for this parasite, seropositivity increased risk of all forms of self-directed violence, and the increased risk of SA and suicide was correlated with concentrations of anti-toxoplasma antibodies. ${ }^{193}$ Toxoplasma seropositivity may also be linked to gender-specific alterations in personality traits associated with SB, specifically increased aggression in women and increased impulsivity in young seropositive men. ${ }^{195}$ These intriguing associations may result in part from the immune response to $T$. gondii, particularly the inflammatory response in the brain, and the modulation of tryptophan availability, which, in addition to slowing parasitic replication, decreases serotonin production and increases levels of the NMDA antagonist, kynurenic acid. ${ }^{196}$ A potential link between increased kyurenic acid, T. gondii infection, and SB has also been reported in cohorts of patients with schizophrenia, ${ }^{197}$ but the overall contribution of $T$. gondii to SB is not universally accepted. ${ }^{198}$

Although most studies investigating inflammatory markers in SB have used blood samples, studies carried out in $\mathrm{CSF}^{191,199}$ or postmortem brain tissue, ${ }^{157,168,200,201}$ have led to the suggestion that suicide might be associated with the recruitment of immune cells and low-grade inflammation in the brain. At the pathophysiological level, it has been proposed that low-grade brain inflammation might modulate glutamatergic neurotransmission. Accordingly, inflammation-induced changes in levels of kynurenic and quinolenic acid (which act as antagonist and agonist at glutamatergic NMDA receptors, respectively) 
may ultimately alter the net stimulation of NMDA receptors, in line with recent report about the antidepressant and anti-suicidal effects of the glutamatergic NMDA receptor antagonist ketamine.

The opioid system - promising avenues

The peptidergic opioid system is composed of a family of opioid peptides and four opioid receptor types (mu, delta, and kappa, as well as the non-canonical N/OFQ receptor) that critically controls pain, ${ }^{202}$

reward, ${ }^{203}$ and mood processes. ${ }^{204}$ Post-mortem studies have examined the $\mu$-opioid receptor (MOR) binding in suicide victims who were mainly diagnosed with depression. Compared with controls, MOR density was increased in frontal and temporal cortices, ${ }^{205-207}$ as well as in caudate nuclei. ${ }^{206}$ Furthermore, positron emission tomography (PET) studies with a MOR selective radiotracer showed that the induction of a sadness state in healthy individuals, ${ }^{208}$ as well as depressed mood in clinical cohorts, ${ }^{209}$ associated with adaptations in MOR neurotransmission across several brain regions. The dynorphin-kappa opioid receptor signaling pathway has also been linked to suicide, with increased ${ }^{210}$ and decreased ${ }^{211}$ expression reported in the caudate nucleus and amygdala, respectively. Interestingly, one the first PET studies on the kappa opioid receptor recently conducted in a dimensional Research Domain Criteria approach found significant relationships between trauma-related psychopathology and bioavailability of this receptor, ${ }^{212}$ with potential implications in the context of ELA and suicide. Finally, a recent report found decreased expression of the N/OFQ receptor in the ACC of suicides. ${ }^{213}$

An emerging line of investigation suggests that the opioid system may be involved in the regulation of emotional pain and social attachment, ${ }^{204,214}$ particularly in relation to SB. ${ }^{215}$ Accordingly, patients typically report that self-injurious behaviors decrease their emotional pain, and this has been proposed to be related to endogenous opioid signaling. ${ }^{216-218}$ In addition, a recent study reported that buprenorphine, an opiate classically used for maintenance therapies in addicted individuals, may decrease severe $\mathrm{SI}$ in patients without substance use disorder. ${ }^{219}$ Future studies will be required to explore the relative contributions of distinct opioid receptors and peptides in these effects, as opioid modulatory therapies gain momentum in the management of depressive conditions. ${ }^{220}$

\section{Neurotrophic pathways}

\section{Neurotrophins}

In important studies examining the expression of the key brain-derived neurotrophic factor (BDNF) in postmortem suicide brains, mRNA expression of both BDNF and its receptor, tyrosine kinase B (TrKB), were shown to be decreased, with concomitant decreases in BDNF and TrkB full-length protein expression. ${ }^{221,222}$ The link between BDNF expression and suicide has since been extensively explored, and despite some conflicting reports regarding serum BDNF levels in suicide attempters, ${ }^{223-225}$ BDNF expression is generally altered in the suicide brain. Some insight into this association has come in part from evidence of increased BDNF promoter/exon 4 DNA methylation in suicide brains, ${ }^{226}$ a finding that is consistent with those observed in depressed patients with a history of SA, or with SI during treatment, ${ }^{227}$ and with evidence of hypermethylation of BDNF exons 4 and 9 induced by ELA in an animal model, ${ }^{228}$ 
which further supports the biological impact of ELA on suicide risk. Finally, there is evidence that treatment of MDD patients with antidepressants relieves epigenetic repression of $B D N F,{ }^{229}$ pointing to its role in mediating depressive phenotypes, and potentially SB. The main receptor of BDNF, TrkB, is also regulated through epigenetic changes that appear to have an impact on suicide risk. In brain tissue from individuals who died by suicide, mRNA expression of the astrocyte-enriched TrkB truncated variant, TrkB-T1, is significantly decreased in association with increased methylation at the TrkB-T1 promoter, and appears to be regulated by the microRNA miR-185. ${ }^{230-232}$

Efforts to describe the impact of BDNF on suicide risk have also focused on a gene polymorphism that produces a Val instead of a Met in codon 66 (Val66Met). Many publications have shown evidence that the BDNF-Met variant is associated with a heightened risk of SB (reviewed in ${ }^{37}$ ), with its effect on suicide risk mediated in part by experiences of child abuse. ${ }^{233,234}$ Importantly, differences between study results have highlighted the importance of considering the particular contributions of sex, ${ }^{235}$ psychiatric diagnosis, ${ }^{236,237}$ and type of $\mathrm{SB}^{236,238,239}$ when interpreting the degree of regulation of SB by a single polymorphism.

\section{Lipid metabolism}

Following strong initial evidence of an association between low peripheral cholesterol levels and suicidality, cholesterol has been investigated as a potential biomarker of SB (reviewed in ${ }^{240}$ ). Evidence that low cholesterol may contribute to suicide and SBs includes low cholesterol levels in the brain of suicides ${ }^{241}$ and in CSF of suicide attempters, ${ }^{242}$ and high rates of suicide and SA in individuals with disrupted cholesterol synthesis and metabolism. ${ }^{243,244}$ However, certain studies provide conflicting evidence as to the relationship between cholesterol and SB. ${ }^{245-247}$ An important consideration is that different forms of cholesterol (LDL vs. HDL) may have differing roles in brain function and suicidality, and a number of other important confounders, such as age, sex, and nutritional status, may also have significant contributions to suicide risk. Nevertheless, cholesterol represents a potentially important player in brain function as nearly one quarter of the body's cholesterol is located in the CNS, ${ }^{248}$ where it is a key component of lipid rafts, acts as a precursor for neurosteroids, is regulated by BDNF, and regulates neural plasticity. ${ }^{240,249}$ Additional evidence suggests that cholesterol may have important implications in neurotransmitter signalling. ${ }^{240}$

Beyond cholesterol, there is evidence that triglyceride levels ${ }^{250,251}$ and regulators of fatty acid composition may also influence suicide risk, particularly in the case of violent SA and suicides. ${ }^{252}$ Of interest, a recent report indicates a potential role for epigenetic regulation of polyunsaturated fatty acid (PUFA) biosynthesis through differential DNA methylation of elongation of very long-chain fatty acids protein 5 (Elovl5) in subjects with MDD with or without a history SA. ${ }^{253}$ The effect of this differential methylation is unclear, however, since the levels of circulating PUFA were not significantly different between groups. ${ }^{253}$ This is also consistent with a previous study reporting no change in fatty acid composition of postmortem brain tissue of suicides with or without MDD, as compared to healthy controls. ${ }^{254}$ Such evidence of the role of lipids in suicide has led to speculation as to the potential for modulating lipid profiles in patients deemed "at-risk", 255 but the evidence to support such interventions is still insufficient. 
Stress response systems

The polyamine stress response system

In addition to the HPA stress response system, the polyamine system, another stress response pathway, has been extensively characterized in relation to suicide risk. Polyamines, aliphatic compounds with multiple amine groups, have been implicated in a host of cellular functions, including the regulation of gene expression at transcriptional and post-transcriptional levels, most notably regulating the function of several neuromodulators (primarily glutamate receptors, but also nicotinic receptors and ion channels), and acting as neurotransmitters themselves. ${ }^{256}$ In particular, there is evidence that the polyamines agmatine, spermine, and spermidine are released at synapses on depolarization. ${ }^{257-259}$ In conditions of physical, hormonal, or emotional stress, the polyamine stress response is activated, with increased expression of putrescine and agmatine in both central and peripheral tissues. ${ }^{260,261}$ Growing evidence suggests that elevated levels of these two polyamines in the brain have antidepressant and anxiolytic effects, potentially through regulation of inflammation. ${ }^{262-264}$ Additionally, agmatine may mediate the activity of pharmacological antidepressants, in part through binding to NMDA receptors. ${ }^{265-}$ 267

Polyamines may play a particular role in the context of suicide, as studies investigating postmortem suicide brains show that expression levels of gene products associated with the polyamine stress response system are dysregulated. ${ }^{268-273}$ Expression of the rate-limiting enzyme spermine N1acetyltransferase (SAT1), as well as of several other polyamine-associated enzymes (SMOX, ODC, SMS, AMC-1), are altered in the cortex of postmortem suicides. ${ }^{270,273,274}$ Individual isoforms of SAT1 may partially explain the decreased SAT1 expression in brain tissue of suicides, ${ }^{268,270,275,276}$ and there is some evidence that microRNAs can target polyamine transcripts including SAT1. ${ }^{277}$ Another important contributor to SAT1 downregulation is through epigenetic control, with studies identifying promoter DNA methylation of SAT1 that inversely correlated with SAT1 expression, and evidence for histone modifications affecting key enzymes in polyamine synthesis. ${ }^{278-280}$ SAT1 has emerged as a potential biomarker for suicide, topping the lists of candidates in several studies. ${ }^{281-283}$

\section{Early-life adversity and the HPA stress axis}

One of the best investigated examples of epigenetic changes in response to ELA is that of the hypothalamic-pituitary-adrenal (HPA) axis, a key regulator of cortisol release and stress response. ${ }^{284}$ Animal models of ELA have long shown that stressful events during early life disrupted glucocorticoid function and altered behavioural responses to stress challenges. ${ }^{285}$ Glucocorticoid release, triggered by stress, is regulated by a negative feedback loop in which secreted steroids activate glucocorticoid receptors (GR) in the hypothalamus, thereby shutting off further production. Ground-breaking studies conducted in rats showed that GR exon $1_{7}$ expression in pups is epigenetically regulated by the early-life environment. ${ }^{286-288}$ In a subsequent postmortem brain study from individuals who had died by suicide and were severely abused during childhood, compared with individuals without a history of child abuse 
(suicide or healthy control), the GR exon $1_{F}$ variant (human homolog to the rodent exon $1_{7}$ ) was also epigenetically regulated in humans by their early-life environment. ${ }^{289}$ As in rodents, the methylation of exon $1_{F}$ was associated with the quality of care in early life, ${ }^{289}$ and its methylation status seems to regulate the binding of the NGFI-A transcription factor associated with GR expression. ${ }^{288,289}$ These findings have since been confirmed in the context of ELA and of parental emotional stress, with increased GR $1_{F} / G R 1_{7}$ methylation in both central nervous system and peripheral tissues. ${ }^{290}$ In contrast, results of studies examining other GR exons or examining adult psychopathology have yielded mixed results. ${ }^{290}$ In addition to this direct decrease of GR expression, there is evidence that GR function may also be altered through the FK506-binding protein (FKBP5), which downregulates GR signalling. Particular sequence variants of FKBP5 have been associated with increased suicidality, ${ }^{291-295}$ particularly in individuals with a history of ELA. ${ }^{296-299}$ Disrupted GR function results in inadequate control of the HPA axis in these individuals, possibly leaving them with hyperactive cortisol secretion, and the development of anxiety traits. In turn, anxiety mediates the relationship between ELA and SB. ${ }^{21,55}$

An exciting new candidate in the relationship between cortisol regulation and suicide is the spindle and kinetochore associated protein 2 (SKA2), a gene that has been implicated in GR signalling. ${ }^{300}$ Recent reports have converged on identifying differential methylation of SKA2 at the level of a single $\mathrm{CpG}$. $^{301,302}$ Increased SKA2 3'UTR methylation, and concomitantly decreased SKA2 mRNA, was detected in suicide brain samples, as well as in peripheral blood samples of individuals with both $\mathrm{SI}$ and SA, compared to controls. ${ }^{302}$ Peripheral samples that were available at time points preceding the onset of $\mathrm{SI}$ also displayed altered SKA2 methylation, pointing to a predictive effect of this marker. A second study confirmed these findings in saliva and blood samples, showing that increased methylation of the SKA2 site correlated with impaired cortisol suppression. ${ }^{301}$ Additionally, combining SKA2 methylation status with history of childhood abuse allowed for a stronger prediction of SA.

\section{Future directions and current challenges for functional genomic research in SB}

Accumulating evidence indicates that epigenetic processes present unique properties in the brain compared to other organs of the human body, as revealed by a unique pattern of non-CG methylation, ${ }^{303}$ high levels of hydroxymethylation, ${ }^{304}$ or the complexity of non-coding RNAs, ${ }^{305}$ among others (Table 1). Brain epigenetics is therefore a distinct field that requires the development of specific analytical tools to address unique experimental challenges.

We can speculate that the brain may have evolved as the most sensitive organ to process changes in environmental conditions to improve adaptation to the environment. Accordingly, over evolutionary time this functional specialization may have required particular, potentially more complex, molecular and epigenetic processes mediating the interplay of the environment and the genome. In addition, because epigenetic changes can be long-lasting (potentially over generations, although this is debated $\left.{ }^{306}\right)$, they represent a form of genomic plasticity that could help explain psychiatric phenotypes, such as depressive illness and SB, that associate with distal environmental stressors such as exposure to 
early-life adversity. ${ }^{307}$ We detail below immediate and long-term research opportunities for brain functional genomic studies investigating SB.

\section{DNA CH methylation}

While DNA methylation is largely restricted to sequences composed of cytosines followed by guanines (known as CG dinucleotides), recent results have identified a non-canonical form of DNA methylation in non- $\mathrm{CG}$, or $\mathrm{CH}$, contexts (where $\mathrm{H}$ stands for $\mathrm{A}, \mathrm{C}$ or $\mathrm{T}$ ). While high levels of $\mathrm{CH}$ methylation $(\mathrm{mCH})$ were first identified in embryonic stem cells (ESCs), ${ }^{308}$ recent findings have revealed that the highest levels of $\mathrm{mCH}$ across mammalian tissues are in the brain. ${ }^{303,309}$ Results also showed that $\mathrm{mCH}$ accumulation is much more pronounced in neurons than in glial cells, ${ }^{303,310}$ and that $\mathrm{mCH}$ levels measured at the whole tissue level (below 5\%) are considerably lower than for the CG context (70-80\%). Nevertheless, the large number of cytosines in $\mathrm{CH}$, compared to $\mathrm{CG}$, contexts, has led to estimates that $\mathrm{mCH}$ may ultimately account for as much as a quarter of all methylated cytosines. ${ }^{309,310}$

Similar to $\mathrm{mCG}, \mathrm{mCH}$ tends to negatively associate with transcriptional activity. It is therefore possible that differences in gene expression associated with suicide might partly result from differential $\mathrm{mCH}$ levels, particularly for genes that are dysregulated in cells with high $\mathrm{mCH}$ levels (i.e., neurons rather than glial or other cell types). Importantly, $\mathrm{mCH}$ may be particularly relevant to so-called 'sensitive periods', defined as time-windows in brain development during which critical processes must take place to achieve proper maturation of essential physiological functions. This concept, which was primarily investigated for sensory-motor functions ${ }^{311}$ and more recently in relation to emotional regulation, ${ }^{312}$ may partly explain the relationship between ELA and suicide. ${ }^{313}$ As mentioned above, ELA is an important predictor of SB, and its effects are thought to be mediated partly through DNA methylation. Considering that $\mathrm{mCH}$ progressively accumulates in neurons during the first few years of life in human, ${ }^{310}$ it is tempting to speculate that this newly identified epigenetic mark may be particularly sensitive to ELA.

Compared with DNA methylation in the canonical CG context, $\mathrm{mCH}$ transcription regulation is only starting to be explored. ${ }^{314}$ Recent reports have established an intriguing link between the length of genes along the DNA sequence and levels of CA DNA methylation. ${ }^{315,316}$ A proposed model ${ }^{317}$ suggests that expression of long genes, as a population, is enriched in the brain and is tightly regulated by enhanced MeCP2 binding due to high mCA levels. While these results were obtained in relationship to Rett syndrome, a neurodevelopmental disorder due to mutations in the MeCP2 gene, they uncover a specific epigenetic function of $\mathrm{mCH}$ that may be relevant to psychopathology and suicide.

\section{Hydroxymethylcytosine}

While methylcytosine is sometimes described as the fifth DNA base, a sixth base has been recently identified $^{304,318}$ that corresponds to a further oxidation step (mediated by Tet-translocation enzymes, Tet1, 2 and 3) from methyl- $(5 \mathrm{mC})$ to hydroxymethylcytosine $(5 \mathrm{hmC})$. This new epigenetic mark appears to be stable in vivo ${ }^{319}$ and to occur in $\mathrm{CG}$ - but not $\mathrm{CH}$ - contexts, indicating that $\mathrm{mCG}$ is uniquely 
susceptible to Tet-mediated oxidation. Similarly to $\mathrm{mCH}, 5 \mathrm{hmC}$ predominantly accumulates in neuronal cells, and its levels are higher in the brain than in any other human tissue. ${ }^{304,320}$ Most techniques used to measure levels of DNA methylation (including the popular bisulfite conversion) do not distinguish between $5 \mathrm{mC}$ and $5 \mathrm{hmC}$, although several methodologies have now been developed to address this (including oxBS-Seq, ${ }^{321} \mathrm{TAB}-\mathrm{Seq}^{322}$ or $\mathrm{Aba-Seq}{ }^{323,324}$ ). $5 \mathrm{mC}$ and $5 \mathrm{hmC}$ seem to have opposite relationships with transcriptional activity, with $5 \mathrm{mC}$ negatively correlating with gene expression, ${ }^{325}$ and $5 \mathrm{hmC}$ positively correlating with expression in rodent ${ }^{326}$ and human ${ }^{324}$ brains. A similar positive relationship was observed for dendritic cells of the immune system, ${ }^{327}$ while gene bodies and enhancer regions in ESCs display a more subtle dual pattern. ${ }^{328}$ There is currently some debate about the specific proteins that dictate this divergent transcriptional regulation. ${ }^{316,329}$ Such complexity again emphasizes the importance of tissue-, or even cell type-specific epigenetic regulatory processes. While $5 \mathrm{hmC}$ has begun to be investigated in neurodegenerative disorders such as Alzheimer's and Huntington's diseases, ${ }^{330,331}$ its potential implication in the understanding of SB remains unknown.

\section{Histone marks}

Histones are essential protein complexes that control chromatin structure and activity and are regulated by post-translational modifications of their $\mathrm{N}$-terminal tails. Distinct histone modifications associate with genomic features, for example, active promoters and enhancer regions are associated with histone 3 lysine 4 (H3K4) trimethylation and H3K27 acetylation, respectively, whereas repressed promoters are associated with $\mathrm{H} 3 \mathrm{~K} 9$ and $\mathrm{H} 3 \mathrm{~K} 27$ dimethylation and trimethylation. While histone modification represents a ubiquitous mechanism for regulating gene transcription, specific contributions of histone modification to the emergence of suicide-related phenotypes have only been explored at the level of candidate genes, ${ }^{230,280}$ and genome-wide approaches should be conducted.

\section{RNA modifications and non-coding RNA}

Transcription, translation and degradation of RNA molecules are well-controlled processes that are regulated by RNA modifications (RNA methylation and pseudouridine), RNA editing, and RNA structure (see ${ }^{305,332}$ for recent reviews). These mechanisms result in complex relationships between RNA and protein levels in the brain as, for example, it has been suggested that only $40 \%$ of the variance in protein levels could be attributed to RNA abundance. ${ }^{333}$ In the mouse brain, RNA methylation primarily corresponds to N6-methyladenosine (6mA), frequently referred to as an epitranscriptomic mark, which affects messenger and non-coding RNAs and is dynamically regulated during brain development. ${ }^{334}$ It has been shown to regulate RNA degradation kinetics and to accumulate in the prefrontal cortex during learning and memory processes at specific loci associated with synaptic function. ${ }^{335}$ In humans, SNPs in two RNA demethylases, FTO and ALKBH5, which are responsible for $6 \mathrm{~mA}$ processing, have been associated with MDD. ${ }^{336,337}$ This suggests that N6-methyladenosine may contribute to the control of mood and emotional responses, and potentially to suicide pathophysiology. 
Another RNA modification is pseudouridine $(\Psi)$, which has been shown to affect hundreds of messenger RNAs. ${ }^{338,339}$ While changes in levels of pseudouridine have been described across tissues and following cellular stress, its potential role in transcriptomic regulation and in brain function remains unexplored.

Conversion of adenosine to inosine residues by deamination (RNA A-to-I editing) relies on an enzymatic pathway ${ }^{340}$ to promote RNA functional diversity (by modulating alternative splicing and microRNA targeting), thereby leading to qualitatively different proteins and potentially fine-tuning genomic responses to rapidly changing environmental demands. ${ }^{341}$ Recently, an association between suicide and a SNP in the adenosine deaminase ADARB1 was reported. ${ }^{342}$ In suicide, dysregulated RNA editing has been reported for the serotonin $5-\mathrm{HT}_{2 \mathrm{C}}$ receptor, with evidence that increased $5-\mathrm{HT}_{2 \mathrm{C}}$ editing in suicide ${ }^{80,343}$ could lead to decreased receptor signalling. In rodent models, ELA has also been associated with increased $5-\mathrm{HT}_{2 \mathrm{C}}$ editing. ${ }^{344}$

Another promising type of epigenetic regulation of gene expression is the role of non-coding RNAs. A large proportion of the transcriptome is composed of regulatory RNAs that do not encode proteins but regulate mRNA transcription, function and availability, and interact directly with DNA regulatory proteins and enzymes. ${ }^{345}$ Among non-coding RNA species, long non-coding RNAs are of particular interest as they are enriched for brain expression ${ }^{346}$ and developmentally regulated, ${ }^{347}$ but less evolutionarily conserved than other RNA species. While preclinical studies start to unravel how IncRNAs may contribute to emotional control, ${ }^{348}$ their role in SB is currently unknown. On the other hand, microRNAs, which are small non-coding RNA molecules between 19-24 nucleotides long, have been implicated in the pathophysiology of mental illness, including MDD. The specific dysregulation of miR function in suicide is just beginning to be appreciated, as reviewed recently. ${ }^{349}$

\section{Cell-type specificity}

Several distinct cell-types are physically intermingled in the brain, and large-scale single-cell RNAsequencing studies have recently started to uncover the transcriptomic underpinnings of cellular diversity. ${ }^{350,351}$ A similar diversity also emerges at the epigenetic level: while all neurons share common genetic material, their distinct gene-expression patterns are regulated by epigenetic processes. ${ }^{352}$ The heterogeneity of neuronal cell types and their physical entanglement represent experimental challenges that severely hamper the detection of potentially subtle cell-type specific adaptations driving complex emotional responses. ${ }^{353}$ Recent rodent studies have demonstrated that depressive-like behaviours ${ }^{354}$ and behavioural responses to antidepressants ${ }^{83}$ may result from molecular adaptations in a minority population of neuronal and non-neuronal cells in a given brain region. Such discrete adaptations are likely missed by studies performed with tissue homogenates, therefore cell-type specific strategies are needed in suicide research. FACS-sorting of nuclei from postmortem tissue recently enabled the study of cell-type specific epigenetic mechanisms of ELA and suicide, and recent technological achievements suggest that similar studies are now feasible at the level of gene expression using either FACS (followed by analyses of nuclear messenger RNAs ${ }^{355}$ ) or laser microdissection. ${ }^{356}$ 


\section{Brain imaging of epigenetic processes}

PET-scan ligands allowing for the visualization of epigenetic enzymes in the human brain have recently been developed. ${ }^{357,358}$ Although the spatial resolution of such approaches will be inherently limited, they should enable longitudinal studies (e.g., of SB) of human brain epigenetic processes that are not feasible with existing biochemical approaches which by definition only capture single epigenetic postmortem 'snapshots'.

\section{Therapeutic perspectives}

Tools are currently being developed to enable potent and specific manipulation of the epigenome with long-term therapeutic potential in the field of molecular psychiatry. Experimental manipulations of the human DNA sequence have been revolutionized over the last few years by the discovery of the Cas 9 system. ${ }^{359}$ The power of Cas9, and other gene targeting strategies, is now being harnessed to manipulate the epigenome. Accordingly, recent reports have shown that enzymes responsible for the methylation of the human DNA (DNMT3a) can be directed to specific loci in vitro ${ }^{360,361}$ in order to modify site-specific DNA methylation patterns. Very recently, similar approaches have been used in vivo ${ }^{362}$ to mediate targeted epigenetic reprogramming in the brain, ${ }^{363}$ with the potential for inheritance. ${ }^{364}$ Importantly, the first experimental approach to take advantage of these recent technologies demonstrated in rodent models that targeted epigenetic modulation of histone methylation (H3K9me2) controlled drug- and stress-induced transcriptional and behavioural responses. ${ }^{362}$ Such tools may eventually allow for epigenetic interventions in psychiatric patients, but a series of major obstacles and challenges remain that are notably related to specificity, safety and efficiency, similar to those that have been encountered historically for gene therapies in other medical fields. ${ }^{365}$

\section{Current challenges in suicide research}

Our understanding of the factors and pathways involved in mediating suicide risk has greatly benefitted from the advances in the last decade. As we improve our ability to investigate more discrete changes, it becomes increasingly important to disentangle the relative contributions of psychopathology from changes specific to suicide. The high rate of co-occurrence of MDD and suicide constitutes a major challenge in identifying selective determinants of suicide and SB. Recent work examining the transmission of violent behaviours and SA also show substantial overlap between these phenotypes, ${ }^{366}$ which may be partly explained by the co-transmission of impulsive-aggressive and SB. ${ }^{10,16}$ Such confounding factors suggest that distinguishing between the etiological factors of distinct psychopathologies and SB may be more complex than was originally anticipated. A further complication stems from the emergence of SI during antidepressant treatment, which has been reported in a small proportion of patients receiving SSRIs. ${ }^{367}$ Although some studies have investigated genetic correlates of treatment-emergent $\mathrm{SI}^{40,368}$ we have yet to adequately describe the clinical and biological features associated with treatment-emergent or treatment-worsening SI.

The wide range of phenotypes that may be considered in studies investigating suicide or suicidal behaviour further complicates identification of clear markers for suicide and SB. SI and SA may at times 
be studied concurrently, and even within these accepted categories, phenotypes may be distinguished on the basis of passive or active engagement, on the presence or absence of planning (SI), and according to the potential lethality, intent and violence (SA). ${ }^{5}$ These phenotypes are often considered to exist on a spectrum and as a result are frequently studied and reported on together. However, reports have also shown specific differences between non-violent and violent SA, ${ }^{185,235,241}$ and similar questions may be asked about the biological similarities between $\mathrm{SI}, \mathrm{SA}$ and suicide. Given the relatively high prevalence of $\mathrm{SI}$, compared to SA and suicide, ${ }^{5}$ reliable indicators of progression to SA or suicide would be of clear clinical benefit. Psychological constructs have been proposed to aid in our understanding of these transitions, ${ }^{369}$ and strengthening this understanding with clearly defined biological mechanisms will provide a crucial opportunity to act before suicide occurs.

\section{Acknowledgements}

The authors are indebted to Sylvanne Daniels for expert and essential help in the preparation of this review. PEL is supported by scholarships from the Fondation Fyssen, the Fondation BettencourtSchueller, the Canadian Institutes of Health Research, the American Foundation for Suicide Prevention, the Fondation pour la Recherche Médicale and the Fondation Deniker. NM is a CIHR New Investigator, and is supported by CIHR grant MOP-111022 and by an ERA-NET NEURON (FRQ-S) team grant. GT holds a Canada Research Chair (Tier 1), Fonds de Recherche du Québec - Santé (FRQS) Chercheur National salary award, and a NARSAD Distinguished Investigator Award. He is supported by grants from the Canadian Institute of Health Research (CIHR) (FDN148374, MOP93775, MOP11260, MOP119429, and MOP119430), from the US National Institutes of Health (NIH) (1R01DA033684), by the FRQS through the Quebec Network on Suicide, Mood Disorders and Related Disorders, and through an investigatorinitiated research grant from Pfizer.

\section{Conflict of interest}

GT has received investigator-initiated grants from Pfizer Canada. 


\section{References}

1. Mental health: suicide prevention. http://www.who.int/mental health/suicide-prevention/en/, 2014, Accessed Date Accessed 2014 Accessed.

2. Borges G, Nock MK, Haro Abad JM, Hwang I, Sampson NA, Alonso J et al. Twelve-month prevalence of and risk factors for suicide attempts in the World Health Organization World Mental Health Surveys. The Journal of clinical psychiatry 2010; 71(12): 1617-1628.

3. Nock MK, Green JG, Hwang I, McLaughlin KA, Sampson NA, Zaslavsky AM et al. Prevalence, correlates, and treatment of lifetime suicidal behavior among adolescents: results from the National Comorbidity Survey Replication Adolescent Supplement. JAMA psychiatry 2013; 70(3): 300-310.

4. Nock MK, Hwang I, Sampson N, Kessler RC, Angermeyer M, Beautrais A et al. Cross-national analysis of the associations among mental disorders and suicidal behavior: findings from the WHO World Mental Health Surveys. PLoS Med 2009; 6(8): e1000123.

5. Turecki G, Brent DA. Suicide and suicidal behaviour. Lancet 2016; 387(10024): 1227-1239.

6. Arsenault-Lapierre G, Kim C, Turecki G. Psychiatric diagnoses in 3275 suicides: a meta-analysis. BMC Psychiatry 2004; 4: 37.

7. Hoertel N, Franco S, Wall MM, Oquendo MA, Kerridge BT, Limosin F et al. Mental disorders and risk of suicide attempt: a national prospective study. Mol Psychiatry 2015; 20(6): 718-726.

8. Hor K, Taylor M. Suicide and schizophrenia: a systematic review of rates and risk factors. Journal of psychopharmacology 2010; 24(4 Suppl): 81-90.

9. Holma KM, Haukka J, Suominen K, Valtonen HM, Mantere O, Melartin TK et al. Differences in incidence of suicide attempts between bipolar I and II disorders and major depressive disorder. Bipolar Disord 2014; 16(6): 652-661.

10. McGirr A, Renaud J, Seguin M, Alda M, Turecki G. Course of major depressive disorder and suicide outcome: a psychological autopsy study. The Journal of clinical psychiatry 2008; 69(6): 966-970. 
11. Holma KM, Melartin TK, Haukka J, Holma IA, Sokero TP, Isometsa ET. Incidence and predictors of suicide attempts in DSM-IV major depressive disorder: a five-year prospective study. Am J Psychiatry 2010; 167(7): 801-808.

12. Sokero TP, Melartin TK, Rytsala HJ, Leskela US, Lestela-Mielonen PS, Isometsa ET. Prospective study of risk factors for attempted suicide among patients with DSM-IV major depressive disorder. $\mathrm{Br} \mathrm{J}$ Psychiatry 2005; 186: 314-318.

13. Brezo J, Bureau A, Merette C, Jomphe V, Barker ED, Vitaro F et al. Differences and similarities in the serotonergic diathesis for suicide attempts and mood disorders: a 22-year longitudinal geneenvironment study. Mol Psychiatry 2010; 15(8): 831-843.

14. Caspi A, Sugden K, Moffitt TE, Taylor A, Craig IW, Harrington H et al. Influence of life stress on depression: moderation by a polymorphism in the 5-HTT gene. Science 2003; 301(5631): 386-389.

15. Brent DA, Bridge J, Johnson BA, Connolly J. Suicidal behavior runs in families. A controlled family study of adolescent suicide victims. Archives of general psychiatry 1996; 53(12): 1145-1152.

16. McGirr A, Alda M, Seguin M, Cabot S, Lesage A, Turecki G. Familial aggregation of suicide explained by cluster $B$ traits: a three-group family study of suicide controlling for major depressive disorder. Am J Psychiatry 2009; 166(10): 1124-1134.

17. O'Connor RC, Nock MK. The psychology of suicidal behaviour. Lancet Psychiatry 2014; 1(1): $73-$ 85.

18. Van Orden KA, Witte TK, Cukrowicz KC, Braithwaite SR, Selby EA, Joiner TE, Jr. The interpersonal theory of suicide. Psychological review 2010; 117(2): 575-600.

19. Mann JJ. Neurobiology of suicidal behaviour. Nat Rev Neurosci 2003; 4(10): 819-828.

20. Moscicki EK. Gender differences in completed and attempted suicides. Annals of epidemiology 1994; 4(2): 152-158.

21. Turecki G. The molecular bases of the suicidal brain. Nat Rev Neurosci 2014; 15(12): 802-816.

22. van Heeringen K, Mann JJ. The neurobiology of suicide. Lancet Psychiatry 2014; 1(1): 63-72. 
23. Oquendo MA, Sullivan GM, Sudol K, Baca-Garcia E, Stanley BH, Sublette ME et al. Toward a biosignature for suicide. Am J Psychiatry 2014; 171(12): 1259-1277.

24. Egeland JA, Sussex JN. Suicide and family loading for affective disorders. JAMA 1985; 254(7): 915-918.

25. Tidemalm D, Runeson B, Waern M, Frisell T, Carlstrom E, Lichtenstein P et al. Familial clustering of suicide risk: a total population study of 11.4 million individuals. Psychological medicine 2011; 41(12): 2527-2534.

26. Fu Q, Heath AC, Bucholz KK, Nelson EC, Glowinski AL, Goldberg J et al. A twin study of genetic and environmental influences on suicidality in men. Psychological medicine 2002; 32(1): 11-24.

27. Statham DJ, Heath AC, Madden PA, Bucholz KK, Bierut L, Dinwiddie SH et al. Suicidal behaviour: an epidemiological and genetic study. Psychological medicine 1998; 28(4): 839-855.

28. Pedersen NL, Fiske A. Genetic influences on suicide and nonfatal suicidal behavior: twin study findings. Eur Psychiatry 2010; 25(5): 264-267.

29. Brent DA, Melhem NM, Oquendo M, Burke A, Birmaher B, Stanley B et al. Familial pathways to early-onset suicide attempt: a 5.6-year prospective study. JAMA psychiatry 2015; 72(2): 160-168.

30. Brent DA, Oquendo M, Birmaher B, Greenhill L, Kolko D, Stanley B et al. Familial transmission of mood disorders: convergence and divergence with transmission of suicidal behavior. J Am Acad Child Adolesc Psychiatry 2004; 43(10): 1259-1266.

31. Kim CD, Seguin M, Therrien N, Riopel G, Chawky N, Lesage AD et al. Familial aggregation of suicidal behavior: a family study of male suicide completers from the general population. $\mathrm{Am} J$ Psychiatry 2005; 162(5): 1017-1019.

32. Sokolowski M, Wasserman J, Wasserman D. An overview of the neurobiology of suicidal behaviors as one meta-system. Mol Psychiatry 2015; 20(1): 56-71.

33. Anguelova M, Benkelfat C, Turecki G. A systematic review of association studies investigating genes coding for serotonin receptors and the serotonin transporter: II. Suicidal behavior. Mol Psychiatry 2003; 8(7): 646-653. 
34. Brezo J, Klempan T, Turecki G. The genetics of suicide: a critical review of molecular studies. Psychiatr Clin North Am 2008; 31(2): 179-203.

35. Mann JJ. The serotonergic system in mood disorders and suicidal behaviour. Philos Trans $R$ Soc Lond B Biol Sci 2013; 368(1615): 20120537.

36. Dwivedi Y. Brain-derived neurotrophic factor and suicide pathogenesis. Ann Med 2010; 42(2): 87-96.

37. Mirkovic B, Laurent C, Podlipski MA, Frebourg T, Cohen D, Gerardin P. Genetic Association Studies of Suicidal Behavior: A Review of the Past 10 Years, Progress, Limitations, and Future Directions. Frontiers in psychiatry 2016; 7: 158.

38. Galfalvy H, Zalsman G, Huang YY, Murphy L, Rosoklija G, Dwork AJ et al. A pilot genome wide association and gene expression array study of suicide with and without major depression. World J Biol Psychiatry 2013; 14(8): 574-582.

39. Galfalvy H, Haghighi F, Hodgkinson C, Goldman D, Oquendo MA, Burke A et al. A genome-wide association study of suicidal behavior. American journal of medical genetics Part B, Neuropsychiatric genetics : the official publication of the International Society of Psychiatric Genetics 2015; 168(7): 557563.

40. Laje G, Allen AS, Akula N, Manji H, John Rush A, McMahon FJ. Genome-wide association study of suicidal ideation emerging during citalopram treatment of depressed outpatients. Pharmacogenet Genomics 2009; 19(9): 666-674.

41. Perlis RH, Huang J, Purcell S, Fava M, Rush AJ, Sullivan PF et al. Genome-wide association study of suicide attempts in mood disorder patients. Am J Psychiatry 2010; 167(12): 1499-1507.

42. Schosser A, Butler AW, Ising M, Perroud N, Uher R, Ng MY et al. Genomewide association scan of suicidal thoughts and behaviour in major depression. PloS one 2011; 6(7): e20690.

43. Menke A, Domschke K, Czamara D, Klengel T, Hennings J, Lucae S et al. Genome-wide association study of antidepressant treatment-emergent suicidal ideation. Neuropsychopharmacology 2012; 37(3): 797-807.

44. Perroud N, Uher R, Ng MY, Guipponi M, Hauser J, Henigsberg N et al. Genome-wide association study of increasing suicidal ideation during antidepressant treatment in the GENDEP project.

Pharmacogenomics J 2012; 12(1): 68-77. 
45. Willour VL, Seifuddin F, Mahon PB, Jancic D, Pirooznia M, Steele J et al. A genome-wide association study of attempted suicide. Mol Psychiatry 2012; 17(4): 433-444.

46. Mullins N, Perroud N, Uher R, Butler AW, Cohen-Woods S, Rivera M et al. Genetic relationships between suicide attempts, suicidal ideation and major psychiatric disorders: a genome-wide association and polygenic scoring study. American journal of medical genetics Part B, Neuropsychiatric genetics : the official publication of the International Society of Psychiatric Genetics 2014; 165b(5): 428-437.

47. Zai CC, Goncalves VF, Tiwari AK, Gagliano SA, Hosang G, de Luca V et al. A genome-wide association study of suicide severity scores in bipolar disorder. Journal of psychiatric research 2015; 65: 23-29.

48. Sokolowski M, Wasserman J, Wasserman D. Polygenic associations of neurodevelopmental genes in suicide attempt. Mol Psychiatry 2016; 21(10): 1381-1390.

49. Bani-Fatemi A, Graff A, Zai C, Strauss J, De Luca V. GWAS analysis of suicide attempt in schizophrenia: Main genetic effect and interaction with early life trauma. Neurosci Lett 2016; 622: 102106.

50. Pocock R, Mione M, Hussain S, Maxwell S, Pontecorvi M, Aslam S et al. Neuronal function of Tbx20 conserved from nematodes to vertebrates. Dev Biol 2008; 317(2): 671-685.

51. Consortium EP. An integrated encyclopedia of DNA elements in the human genome. Nature 2012; 489(7414): 57-74.

52. Fergusson DM, Woodward LJ, Horwood LJ. Risk factors and life processes associated with the onset of suicidal behaviour during adolescence and early adulthood. Psychological medicine 2000; 30(1): 23-39.

53. Smith PN, Gamble SA, Cort NA, Ward EA, Conwell Y, Talbot NL. The relationships of attachment style and social maladjustment to death ideation in depressed women with a history of childhood sexual abuse. J Clin Psychol 2012; 68(1): 78-87.

54. Brezo J, Paris J, Vitaro F, Hebert M, Tremblay RE, Turecki G. Predicting suicide attempts in young adults with histories of childhood abuse. BrJ Psychiatry 2008; 193(2): 134-139. 
55. Wanner B, Vitaro F, Tremblay RE, Turecki G. Childhood trajectories of anxiousness and disruptiveness explain the association between early-life adversity and attempted suicide. Psychological medicine 2012; 42(11): 2373-2382.

56. Brezo J, Paris J, Barker ED, Tremblay R, Vitaro F, Zoccolillo M et al. Natural history of suicidal behaviors in a population-based sample of young adults. Psychological medicine 2007; 37(11): 15631574.

57. Lopez-Castroman J, Jaussent I, Beziat S, Genty C, Olie E, de Leon-Martinez V et al. Suicidal phenotypes associated with family history of suicidal behavior and early traumatic experiences. J Affect Disord 2012; 142(1-3): 193-199.

58. Lopez-Castroman J, Melhem N, Birmaher B, Greenhill L, Kolko D, Stanley B et al. Early childhood sexual abuse increases suicidal intent. World psychiatry : official journal of the World Psychiatric Association 2013; 12(2): 149-154.

59. Turecki G, Ota VK, Belangero SI, Jackowski A, Kaufman J. Early life adversity, genomic plasticity, and psychopathology. Lancet Psychiatry 2014; 1(6): 461-466.

60. Labonte B, Suderman M, Maussion G, Lopez JP, Navarro-Sanchez L, Yerko V et al. Genome-wide methylation changes in the brains of suicide completers. Am J Psychiatry 2013; 170(5): 511-520.

61. Schneider E, El Hajj N, Muller F, Navarro B, Haaf T. Epigenetic Dysregulation in the Prefrontal Cortex of Suicide Completers. Cytogenet Genome Res 2015; 146(1): 19-27.

62. Nagy C, Suderman M, Yang J, Szyf M, Mechawar N, Ernst C et al. Astrocytic abnormalities and global DNA methylation patterns in depression and suicide. Mol Psychiatry 2015; 20(3): 320-328.

63. Asberg M, Thoren P, Traskman L, Bertilsson L, Ringberger V. "Serotonin depression"--a biochemical subgroup within the affective disorders? Science 1976; 191(4226): 478-480.

64. Boldrini M, Underwood MD, Mann JJ, Arango V. Serotonin-1A autoreceptor binding in the dorsal raphe nucleus of depressed suicides. Journal of psychiatric research 2008; 42(6): 433-442.

65. Bach H, Arango V. Neuroanatomy of Serotonergic Abnormalities in Suicide. In: Dwivedi Y (ed). The Neurobiological Basis of Suicide: Boca Raton (FL), 2012. 
66. Kaufman J, Sullivan GM, Yang J, Ogden RT, Miller JM, Oquendo MA et al. Quantification of the Serotonin 1A Receptor Using PET: Identification of a Potential Biomarker of Major Depression in Males. Neuropsychopharmacology 2015; 40(7): 1692-1699.

67. Antypa N, Serretti A, Rujescu D. Serotonergic genes and suicide: a systematic review. European neuropsychopharmacology : the journal of the European College of Neuropsychopharmacology 2013; 23(10): 1125-1142.

68. Sudol K, Mann JJ. Biomarkers of Suicide Attempt Behavior: Towards a Biological Model of Risk. Current psychiatry reports 2017; 19(6): 31.

69. Arango V, Underwood MD, Boldrini M, Tamir H, Kassir SA, Hsiung S et al. Serotonin $1 \mathrm{~A}$ receptors, serotonin transporter binding and serotonin transporter mRNA expression in the brainstem of depressed suicide victims. Neuropsychopharmacology 2001; 25(6): 892-903.

70. Boldrini M, Underwood MD, Mann JJ, Arango V. More tryptophan hydroxylase in the brainstem dorsal raphe nucleus in depressed suicides. Brain Res 2005; 1041(1): 19-28.

71. Bach-Mizrachi H, Underwood MD, Kassir SA, Bakalian MJ, Sibille E, Tamir H et al. Neuronal tryptophan hydroxylase mRNA expression in the human dorsal and median raphe nuclei: major depression and suicide. Neuropsychopharmacology 2006; 31(4): 814-824.

72. Drevets WC, Thase ME, Moses-Kolko EL, Price J, Frank E, Kupfer DJ et al. Serotonin-1A receptor imaging in recurrent depression: replication and literature review. Nucl Med Biol 2007; 34(7): 865-877.

73. Bach-Mizrachi H, Underwood MD, Tin A, Ellis SP, Mann JJ, Arango V. Elevated expression of tryptophan hydroxylase-2 mRNA at the neuronal level in the dorsal and median raphe nuclei of depressed suicides. Mol Psychiatry 2008; 13(5): 507-513, 465.

74. Sullivan GM, Oquendo MA, Milak M, Miller JM, Burke A, Ogden RT et al. Positron emission tomography quantification of serotonin $(1 \mathrm{~A})$ receptor binding in suicide attempters with major depressive disorder. JAMA psychiatry 2015; 72(2): 169-178.

75. Wang $L$, Zhou $C$, Zhu D, Wang $X$, Fang $L$, Zhong J et al. Serotonin-1A receptor alterations in depression: a meta-analysis of molecular imaging studies. BMC Psychiatry 2016; 16(1): 319.

76. Jokinen J, Nordstrom AL, Nordstrom P. CSF 5-HIAA and DST non-suppression--orthogonal biologic risk factors for suicide in male mood disorder inpatients. Psychiatry research 2009; 165(1-2): 96102. 
77. Miller JM, Hesselgrave N, Ogden RT, Sullivan GM, Oquendo MA, Mann JJ et al. Positron emission tomography quantification of serotonin transporter in suicide attempters with major depressive disorder. Biological psychiatry 2013; 74(4): 287-295.

78. Arango V, Underwood MD, Mann JJ. Serotonin brain circuits involved in major depression and suicide. Prog Brain Res 2002; 136: 443-453.

79. Lopez-Castroman J, Jaussent I, Beziat S, Guillaume S, Baca-Garcia E, Genty C et al. Increased severity of suicidal behavior in impulsive aggressive patients exposed to familial adversities. Psychological medicine 2014; 44(14): 3059-3068.

80. Dracheva S, Patel N, Woo DA, Marcus SM, Siever LJ, Haroutunian V. Increased serotonin 2C receptor mRNA editing: a possible risk factor for suicide. Mol Psychiatry 2008; 13(11): 1001-1010.

81. Schmauss $C$. Serotonin $2 C$ receptors: suicide, serotonin, and runaway RNA editing. The Neuroscientist : a review journal bringing neurobiology, neurology and psychiatry 2003; 9(4): 237-242.

82. Bjork K, Svenningsson P. Modulation of monoamine receptors by adaptor proteins and lipid rafts: role in some effects of centrally acting drugs and therapeutic agents. Annu Rev Pharmacol Toxicol 2011; 51: 211-242.

83. Schmidt EF, Warner-Schmidt JL, Otopalik BG, Pickett SB, Greengard P, Heintz N. Identification of the Cortical Neurons that Mediate Antidepressant Responses. Cell 2012; 149(5): 1152-1163.

84. Svenningsson $\mathrm{P}$, Chergui $\mathrm{K}$, Rachleff I, Flajolet $\mathrm{M}$, Zhang $\mathrm{X}$, El Yacoubi $\mathrm{M}$ et al. Alterations in 5HT1B receptor function by $\mathrm{p} 11$ in depression-like states. Science 2006; 311(5757): 77-80.

85. Lutz PE. Multiple serotonergic paths to antidepressant efficacy. Journal of neurophysiology 2013; 109(9): 2245-2249.

86. Lucas G, Rymar VV, Du J, Mnie-Filali O, Bisgaard C, Manta S et al. Serotonin(4) (5-HT(4)) receptor agonists are putative antidepressants with a rapid onset of action. Neuron 2007; 55(5): 712-725.

87. Schildkraut JJ. The catecholamine hypothesis of affective disorders: a review of supporting evidence. Am J Psychiatry 1965; 122(5): 509-522. 
88. Ordway GA, Smith KS, Haycock JW. Elevated tyrosine hydroxylase in the locus coeruleus of suicide victims. J Neurochem 1994; 62(2): 680-685.

89. Zhu MY, Klimek V, Dilley GE, Haycock JW, Stockmeier C, Overholser JC et al. Elevated levels of tyrosine hydroxylase in the locus coeruleus in major depression. Biological psychiatry 1999; 46(9): 12751286.

90. Biegon A, Fieldust S. Reduced tyrosine hydroxylase immunoreactivity in locus coeruleus of suicide victims. Synapse 1992; 10(1): 79-82.

91. Arango V, Underwood MD, Mann JJ. Fewer pigmented locus coeruleus neurons in suicide victims: preliminary results. Biological psychiatry 1996; 39(2): 112-120.

92. Baumann B, Danos P, Diekmann S, Krell D, Bielau H, Geretsegger C et al. Tyrosine hydroxylase immunoreactivity in the locus coeruleus is reduced in depressed non-suicidal patients but normal in depressed suicide patients. Eur Arch Psychiatry Clin Neurosci 1999; 249(4): 212-219.

93. Syed A, Chatfield M, Matthews F, Harrison P, Brayne C, Esiri MM. Depression in the elderly: pathological study of raphe and locus ceruleus. Neuropathol Appl Neurobiol 2005; 31(4): 405-413.

94. Chandley MJ, Szebeni K, Szebeni A, Crawford J, Stockmeier CA, Turecki G et al. Gene expression deficits in pontine locus coeruleus astrocytes in men with major depressive disorder. J Psychiatry Neurosci 2013; 38(4): 276-284.

95. Chandley MJ, Szebeni A, Szebeni K, Crawford JD, Stockmeier CA, Turecki G et al. Elevated gene expression of glutamate receptors in noradrenergic neurons from the locus coeruleus in major depression. The international journal of neuropsychopharmacology / official scientific journal of the Collegium Internationale Neuropsychopharmacologicum 2014; 17(10): 1569-1578.

96. Stockmeier CA, Mahajan GJ, Konick LC, Overholser JC, Jurjus GJ, Meltzer HY et al. Cellular changes in the postmortem hippocampus in major depression. Biological psychiatry 2004; 56(9): 640650.

97. Videbech P, Ravnkilde B. Hippocampal volume and depression: a meta-analysis of MRI studies. Am J Psychiatry 2004; 161(11): 1957-1966.

98. Sheline $\mathrm{YI}$, Gado MH, Kraemer HC. Untreated depression and hippocampal volume loss. Am J Psychiatry 2003; 160(8): 1516-1518. 
99. Dranovsky A, Hen R. Hippocampal neurogenesis: regulation by stress and antidepressants. Biological psychiatry 2006; 59(12): 1136-1143.

100. Perera TD, Coplan JD, Lisanby SH, Lipira CM, Arif M, Carpio C et al. Antidepressant-induced neurogenesis in the hippocampus of adult nonhuman primates. J Neurosci 2007; 27(18): 4894-4901.

101. Santarelli L, Saxe M, Gross C, Surget A, Battaglia F, Dulawa S et al. Requirement of hippocampal neurogenesis for the behavioral effects of antidepressants. Science 2003; 301(5634): 805-809.

102. Surget A, Tanti A, Leonardo ED, Laugeray A, Rainer Q, Touma C et al. Antidepressants recruit new neurons to improve stress response regulation. Mol Psychiatry 2011; 16(12): 1177-1188.

103. Hill AS, Sahay A, Hen R. Increasing Adult Hippocampal Neurogenesis is Sufficient to Reduce Anxiety and Depression-Like Behaviors. Neuropsychopharmacology 2015; 40(10): 2368-2378.

104. Boldrini M, Underwood MD, Hen R, Rosoklija GB, Dwork AJ, John Mann J et al. Antidepressants increase neural progenitor cells in the human hippocampus. Neuropsychopharmacology 2009; 34(11): 2376-2389.

105. Boldrini M, Hen R, Underwood MD, Rosoklija GB, Dwork AJ, Mann JJ et al. Hippocampal angiogenesis and progenitor cell proliferation are increased with antidepressant use in major depression. Biological psychiatry 2012; 72(7): 562-571.

106. Boldrini M, Santiago AN, Hen R, Dwork AJ, Rosoklija GB, Tamir H et al. Hippocampal granule neuron number and dentate gyrus volume in antidepressant-treated and untreated major depression. Neuropsychopharmacology 2013; 38(6): 1068-1077.

107. Bielau H, Steiner J, Mawrin C, Trubner K, Brisch R, Meyer-Lotz G et al. Dysregulation of GABAergic neurotransmission in mood disorders: a postmortem study. Ann N Y Acad Sci 2007; 1096: 157-169.

108. Law AJ, Harrison PJ. The distribution and morphology of prefrontal cortex pyramidal neurons identified using anti-neurofilament antibodies SMI32, N200 and FNP7. Normative data and a comparison in subjects with schizophrenia, bipolar disorder or major depression. Journal of psychiatric research 2003; 37(6): 487-499. 
109. Rajkowska G, Miguel-Hidalgo JJ, Wei J, Dilley G, Pittman SD, Meltzer HY et al. Morphometric evidence for neuronal and glial prefrontal cell pathology in major depression. Biological psychiatry 1999; 45(9): 1085-1098.

110. Rajkowska G, O'Dwyer G, Teleki Z, Stockmeier CA, Miguel-Hidalgo JJ. GABAergic neurons immunoreactive for calcium binding proteins are reduced in the prefrontal cortex in major depression. Neuropsychopharmacology 2007; 32(2): 471-482.

111. Sequeira A, Mamdani F, Ernst C, Vawter MP, Bunney WE, Lebel V et al. Global brain gene expression analysis links glutamatergic and GABAergic alterations to suicide and major depression. PloS one 2009; 4(8): e6585.

112. Choudary PV, Molnar M, Evans SJ, Tomita H, Li JZ, Vawter MP et al. Altered cortical glutamatergic and GABAergic signal transmission with glial involvement in depression. Proceedings of the National Academy of Sciences of the United States of America 2005; 102(43): 15653-15658.

113. Klempan TA, Sequeira A, Canetti L, Lalovic A, Ernst C, ffrench-Mullen J et al. Altered expression of genes involved in ATP biosynthesis and GABAergic neurotransmission in the ventral prefrontal cortex of suicides with and without major depression. Mol Psychiatry 2009; 14(2): 175-189.

114. Auer DP, Putz B, Kraft E, Lipinski B, Schill J, Holsboer F. Reduced glutamate in the anterior cingulate cortex in depression: an in vivo proton magnetic resonance spectroscopy study. Biological psychiatry 2000; 47(4): 305-313.

115. Mirza Y, Tang J, Russell A, Banerjee SP, Bhandari R, Ivey J et al. Reduced anterior cingulate cortex glutamatergic concentrations in childhood major depression. J Am Acad Child Adolesc Psychiatry 2004; 43(3): 341-348.

116. Frye MA, Watzl J, Banakar S, O'Neill J, Mintz J, Davanzo P et al. Increased anterior cingulate/medial prefrontal cortical glutamate and creatine in bipolar depression. Neuropsychopharmacology 2007; 32(12): 2490-2499.

117. Ballmaier M, Toga AW, Blanton RE, Sowell ER, Lavretsky H, Peterson J et al. Anterior cingulate, gyrus rectus, and orbitofrontal abnormalities in elderly depressed patients: an MRI-based parcellation of the prefrontal cortex. Am J Psychiatry 2004; 161(1): 99-108.

118. Coryell W, Nopoulos P, Drevets W, Wilson T, Andreasen NC. Subgenual prefrontal cortex volumes in major depressive disorder and schizophrenia: diagnostic specificity and prognostic implications. Am J Psychiatry 2005; 162(9): 1706-1712. 
119. Konarski JZ, Mclntyre RS, Kennedy SH, Rafi-Tari S, Soczynska JK, Ketter TA. Volumetric neuroimaging investigations in mood disorders: bipolar disorder versus major depressive disorder. Bipolar Disord 2008; 10(1): 1-37.

120. Bremner JD, Vythilingam M, Vermetten E, Vaccarino V, Charney DS. Deficits in hippocampal and anterior cingulate functioning during verbal declarative memory encoding in midlife major depression. Am J Psychiatry 2004; 161(4): 637-645.

121. Mannie ZN, Norbury R, Murphy SE, Inkster B, Harmer CJ, Cowen PJ. Affective modulation of anterior cingulate cortex in young people at increased familial risk of depression. Br J Psychiatry 2008; 192(5): 356-361.

122. Holmes AJ, Pizzagalli DA. Response conflict and frontocingulate dysfunction in unmedicated participants with major depression. Neuropsychologia 2008; 46(12): 2904-2913.

123. Bunge SA, Klingberg T, Jacobsen RB, Gabrieli JD. A resource model of the neural basis of executive working memory. Proceedings of the National Academy of Sciences of the United States of America 2000; 97(7): 3573-3578.

124. Zhang JX, Leung HC, Johnson MK. Frontal activations associated with accessing and evaluating information in working memory: an fMRI study. Neuroimage 2003; 20(3): 1531-1539.

125. Herman JP, Ostrander MM, Mueller NK, Figueiredo H. Limbic system mechanisms of stress regulation: hypothalamo-pituitary-adrenocortical axis. Progress in neuro-psychopharmacology \& biological psychiatry 2005; 29(8): 1201-1213.

126. Drevets WC. Neuroimaging studies of mood disorders. Biological psychiatry 2000; 48(8): 813829.

127. Fales CL, Barch DM, Rundle MM, Mintun MA, Mathews J, Snyder AZ et al. Antidepressant treatment normalizes hypoactivity in dorsolateral prefrontal cortex during emotional interference processing in major depression. J Affect Disord 2009; 112(1-3): 206-211.

128. Vasic N, Walter H, Sambataro F, Wolf RC. Aberrant functional connectivity of dorsolateral prefrontal and cingulate networks in patients with major depression during working memory processing. Psychological medicine 2009; 39(6): 977-987. 
129. Grieve SM, Korgaonkar MS, Koslow SH, Gordon E, Williams LM. Widespread reductions in gray matter volume in depression. Neuroimage Clin 2013; 3: 332-339.

130. Hercher C, Canetti L, Turecki G, Mechawar N. Anterior cingulate pyramidal neurons display altered dendritic branching in depressed suicides. Journal of psychiatric research 2010; 44(5): 286-293.

131. Poulter MO, Du L, Zhurov V, Palkovits M, Faludi G, Merali Z et al. Altered Organization of GABA(A) Receptor mRNA Expression in the Depressed Suicide Brain. Front Mol Neurosci 2010; 3: 3.

132. Yin H, Pantazatos SP, Galfalvy H, Huang YY, Rosoklija GB, Dwork AJ et al. A pilot integrative genomics study of GABA and glutamate neurotransmitter systems in suicide, suicidal behavior, and major depressive disorder. American journal of medical genetics Part $B$, Neuropsychiatric genetics : the official publication of the International Society of Psychiatric Genetics 2016; 171b(3): 414-426.

133. Poulter MO, Du L, Weaver IC, Palkovits M, Faludi G, Merali Z et al. GABAA receptor promoter hypermethylation in suicide brain: implications for the involvement of epigenetic processes. Biological psychiatry 2008; 64(8): 645-652.

134. Gray AL, Hyde TM, Deep-Soboslay A, Kleinman JE, Sodhi MS. Sex differences in glutamate receptor gene expression in major depression and suicide. Mol Psychiatry 2015; 20(9): 1057-1068.

135. Zhao J, Verwer RW, van Wamelen DJ, Qi XR, Gao SF, Lucassen PJ et al. Prefrontal changes in the glutamate-glutamine cycle and neuronal/glial glutamate transporters in depression with and without suicide. Journal of psychiatric research 2016; 82: 8-15.

136. Berman RM, Cappiello A, Anand A, Oren DA, Heninger GR, Charney DS et al. Antidepressant effects of ketamine in depressed patients. Biological psychiatry 2000; 47(4): 351-354.

137. McGirr A, Berlim MT, Bond DJ, Fleck MP, Yatham LN, Lam RW. A systematic review and metaanalysis of randomized, double-blind, placebo-controlled trials of ketamine in the rapid treatment of major depressive episodes. Psychological medicine 2015; 45(4): 693-704.

138. Zarate CA, Jr., Singh JB, Carlson PJ, Brutsche NE, Ameli R, Luckenbaugh DA et al. A randomized trial of an N-methyl-D-aspartate antagonist in treatment-resistant major depression. Archives of general psychiatry 2006; 63(8): 856-864.

139. Price RB, Nock MK, Charney DS, Mathew SJ. Effects of intravenous ketamine on explicit and implicit measures of suicidality in treatment-resistant depression. Biological psychiatry 2009; 66(5): 522526. 
140. Rajkumar R, Fam J, Yeo EY, Dawe GS. Ketamine and suicidal ideation in depression: Jumping the gun? Pharmacol Res 2015; 99: 23-35.

141. Ionescu DF, Swee MB, Pavone KJ, Taylor N, Akeju O, Baer L et al. Rapid and Sustained Reductions in Current Suicidal Ideation Following Repeated Doses of Intravenous Ketamine: Secondary Analysis of an Open-Label Study. The Journal of clinical psychiatry 2016; 77(6): e719-725.

142. Stenovec M, Lasic E, Bozic M, Bobnar ST, Stout RF, Jr., Grubisic V et al. Ketamine Inhibits ATPEvoked Exocytotic Release of Brain-Derived Neurotrophic Factor from Vesicles in Cultured Rat Astrocytes. Molecular neurobiology 2015.

143. Grieco SF, Cheng Y, Eldar-Finkelman H, Jope RS, Beurel E. Up-regulation of insulin-like growth factor 2 by ketamine requires glycogen synthase kinase-3 inhibition. Progress in neuropsychopharmacology \& biological psychiatry 2017; 72: 49-54.

144. Ren Z, Pribiag H, Jefferson SJ, Shorey M, Fuchs T, Stellwagen D et al. Bidirectional Homeostatic Regulation of a Depression-Related Brain State by Gamma-Aminobutyric Acidergic Deficits and Ketamine Treatment. Biological psychiatry 2016; 80(6): 457-468.

145. Zanos P, Moaddel R, Morris PJ, Georgiou P, Fischell J, Elmer Gl et al. NMDAR inhibitionindependent antidepressant actions of ketamine metabolites. Nature 2016; 533(7604): 481-486.

146. Beurel E, Grieco SF, Amadei C, Downey K, Jope RS. Ketamine-induced inhibition of glycogen synthase kinase-3 contributes to the augmentation of alpha-amino-3-hydroxy-5-methylisoxazole-4propionic acid (AMPA) receptor signaling. Bipolar Disord 2016; 18(6): 473-480.

147. Grieco SF, Velmeshev D, Magistri M, Eldar-Finkelman H, Faghihi MA, Jope RS et al. Ketamine upregulates a cluster of intronic miRNAs within the serotonin receptor $2 \mathrm{C}$ gene by inhibiting glycogen synthase kinase-3. World J Biol Psychiatry 2016: 1-12.

148. Janak PH, Tye KM. From circuits to behaviour in the amygdala. Nature 2015; 517(7534): 284292.

149. Sheline YI, Gado MH, Price JL. Amygdala core nuclei volumes are decreased in recurrent major depression. Neuroreport 1998; 9(9): 2023-2028. 
150. Monkul ES, Hatch JP, Nicoletti MA, Spence S, Brambilla P, Lacerda AL et al. Fronto-limbic brain structures in suicidal and non-suicidal female patients with major depressive disorder. Mol Psychiatry 2007; 12(4): 360-366.

151. Rubinow MJ, Mahajan G, May W, Overholser JC, Jurjus GJ, Dieter L et al. Basolateral amygdala volume and cell numbers in major depressive disorder: a postmortem stereological study. Brain Struct Funct 2016; 221(1): 171-184.

152. Maheu ME, Davoli MA, Turecki G, Mechawar N. Amygdalar expression of proteins associated with neuroplasticity in major depression and suicide. Journal of psychiatric research 2013; 47(3): 384390.

153. Douillard-Guilloux G, Lewis D, Seney ML, Sibille E. Decrease in somatostatin-positive cell density in the amygdala of females with major depression. Depression and anxiety 2016.

154. Cotter D, Landau S, Beasley C, Stevenson R, Chana G, MacMillan L et al. The density and spatial distribution of GABAergic neurons, labelled using calcium binding proteins, in the anterior cingulate cortex in major depressive disorder, bipolar disorder, and schizophrenia. Biological psychiatry 2002; 51(5): 377-386.

155. Uranova NA, Vostrikov VM, Orlovskaya DD, Rachmanova VI. Oligodendroglial density in the prefrontal cortex in schizophrenia and mood disorders: a study from the Stanley Neuropathology Consortium. Schizophrenia research 2004; 67(2-3): 269-275.

156. Rajkowska G, Mahajan G, Maciag D, Sathyanesan M, lyo AH, Moulana M et al. Oligodendrocyte morphometry and expression of myelin - Related mRNA in ventral prefrontal white matter in major depressive disorder. Journal of psychiatric research 2015; 65: 53-62.

157. Steiner J, Bielau H, Brisch R, Danos P, Ullrich O, Mawrin C et al. Immunological aspects in the neurobiology of suicide: elevated microglial density in schizophrenia and depression is associated with suicide. Journal of psychiatric research 2008; 42(2): 151-157.

158. Ongur D, Drevets WC, Price JL. Glial reduction in the subgenual prefrontal cortex in mood disorders. Proceedings of the National Academy of Sciences of the United States of America 1998; 95(22): 13290-13295.

159. Hercher C, Parent M, Flores C, Canetti L, Turecki G, Mechawar N. Alcohol dependence-related increase of glial cell density in the anterior cingulate cortex of suicide completers. $J$ Psychiatry Neurosci 2009; 34(4): 281-288. 
160. Bowley MP, Drevets WC, Ongur D, Price JL. Low glial numbers in the amygdala in major depressive disorder. Biological psychiatry 2002; 52(5): 404-412.

161. Hamidi M, Drevets WC, Price JL. Glial reduction in amygdala in major depressive disorder is due to oligodendrocytes. Biological psychiatry 2004; 55(6): 563-569.

162. Maheu M, Lopez JP, Crapper L, Davoli MA, Turecki G, Mechawar N. MicroRNA regulation of central glial cell line-derived neurotrophic factor (GDNF) signalling in depression. Translational psychiatry 2015; 5: e511.

163. Wilkins A, Majed H, Layfield R, Compston A, Chandran S. Oligodendrocytes promote neuronal survival and axonal length by distinct intracellular mechanisms: a novel role for oligodendrocyte-derived glial cell line-derived neurotrophic factor. J Neurosci 2003; 23(12): 4967-4974.

164. Colombo E, Farina C. Astrocytes: Key Regulators of Neuroinflammation. Trends in immunology 2016; 37(9): 608-620.

165. Oberheim NA, Goldman SA, Nedergaard M. Heterogeneity of astrocytic form and function. Methods Mol Biol 2012; 814: 23-45.

166. Banasr M, Chowdhury GM, Terwilliger R, Newton SS, Duman RS, Behar KL et al. Glial pathology in an animal model of depression: reversal of stress-induced cellular, metabolic and behavioral deficits by the glutamate-modulating drug riluzole. Mol Psychiatry 2010; 15(5): 501-511.

167. Czeh B, Fuchs E, Flugge G. Altered glial plasticity in animal models for mood disorders. Curr Drug Targets 2013; 14(11): 1249-1261.

168. Torres-Platas SG, Cruceanu C, Chen GG, Turecki G, Mechawar N. Evidence for increased microglial priming and macrophage recruitment in the dorsal anterior cingulate white matter of depressed suicides. Brain, behavior, and immunity 2014.

169. Schnieder TP, Trencevska I, Rosoklija G, Stankov A, Mann JJ, Smiley J et al. Microglia of prefrontal white matter in suicide. J Neuropathol Exp Neurol 2014; 73(9): 880-890.

170. Torres-Platas SG, Hercher C, Davoli MA, Maussion G, Labonte B, Turecki G et al. Astrocytic Hypertrophy in Anterior Cingulate White Matter of Depressed Suicides. Neuropsychopharmacology 2011. 
171. Mechawar N, Savitz J. Neuropathology of mood disorders: do we see the stigmata of inflammation? Translational psychiatry 2016; 6(11): e946.

172. Torres-Platas SG, Nagy C, Wakid M, Turecki G, Mechawar N. Glial fibrillary acidic protein is differentially expressed across cortical and subcortical regions in healthy brains and downregulated in the thalamus and caudate nucleus of depressed suicides. Mol Psychiatry 2016; 21(4): 509-515.

173. Ernst C, Nagy C, Kim S, Yang JP, Deng X, Hellstrom IC et al. Dysfunction of Astrocyte Connexins 30 and 43 in Dorsal Lateral Prefrontal Cortex of Suicide Completers. Biological psychiatry 2011.

174. Ezan P, Andre P, Cisternino S, Saubamea B, Boulay AC, Doutremer S et al. Deletion of astroglial connexins weakens the blood-brain barrier. J Cereb Blood Flow Metab 2012; 32(8): 1457-1467.

175. Ventorp F, Barzilay R, Erhardt S, Samuelsson M, Traskman-Bendz L, Janelidze S et al. The CD44 ligand hyaluronic acid is elevated in the cerebrospinal fluid of suicide attempters and is associated with increased blood-brain barrier permeability. J Affect Disord 2016; 193: 349-354.

176. Muller MB, Lucassen PJ, Yassouridis A, Hoogendijk WJ, Holsboer F, Swaab DF. Neither major depression nor glucocorticoid treatment affects the cellular integrity of the human hippocampus. Eur $J$ Neurosci 2001; 14(10): 1603-1612.

177. Cobb JA, O'Neill K, Milner J, Mahajan GJ, Lawrence TJ, May WL et al. Density of GFAPimmunoreactive astrocytes is decreased in left hippocampi in major depressive disorder. Neuroscience 2016; 316: 209-220.

178. Brundin L, Bryleva EY, Thirtamara Rajamani K. Role of Inflammation in Suicide: From Mechanisms to Treatment. Neuropsychopharmacology 2016.

179. Courtet P, Giner L, Seneque M, Guillaume S, Olie E, Ducasse D. Neuroinflammation in suicide: Toward a comprehensive model. World J Biol Psychiatry 2015: 1-23.

180. Raison CL, Capuron L, Miller AH. Cytokines sing the blues: inflammation and the pathogenesis of depression. Trends in immunology 2006; 27(1): 24-31.

181. Kayser MS, Dalmau J. The emerging link between autoimmune disorders and neuropsychiatric disease. J Neuropsychiatry Clin Neurosci 2011; 23(1): 90-97. 
182. Egeberg A, Hansen PR, Gislason GH, Skov L, Mallbris L. Risk of self-harm and nonfatal suicide attempts, and completed suicide in patients with psoriasis: a population-based cohort study. The British journal of dermatology 2016; 175(3): 493-500.

183. Reichenberg A, Yirmiya R, Schuld A, Kraus T, Haack M, Morag A et al. Cytokine-associated emotional and cognitive disturbances in humans. Archives of general psychiatry 2001; 58(5): 445-452.

184. Capuron L, Miller AH. Cytokines and psychopathology: lessons from interferon-alpha. Biological psychiatry 2004; 56(11): 819-824.

185. Lindqvist D, Janelidze S, Hagell P, Erhardt S, Samuelsson M, Minthon L et al. Interleukin-6 is elevated in the cerebrospinal fluid of suicide attempters and related to symptom severity. Biological psychiatry 2009; 66(3): 287-292.

186. Janelidze S, Suchankova P, Ekman A, Erhardt S, Sellgren C, Samuelsson M et al. Low IL-8 is associated with anxiety in suicidal patients: genetic variation and decreased protein levels. Acta Psychiatr Scand 2014.

187. Black C, Miller BJ. Meta-Analysis of Cytokines and Chemokines in Suicidality: Distinguishing Suicidal Versus Nonsuicidal Patients. Biological psychiatry 2015; 78(1): 28-37.

188. Janelidze S, Mattei D, Westrin A, Traskman-Bendz L, Brundin L. Cytokine levels in the blood may distinguish suicide attempters from depressed patients. Brain, behavior, and immunity 2011; 25(2): 335339.

189. Serafini G, Pompili M, Elena Seretti M, Stefani H, Palermo M, Coryell W et al. The role of inflammatory cytokines in suicidal behavior: a systematic review. European neuropsychopharmacology : the journal of the European College of Neuropsychopharmacology 2013; 23(12): 1672-1686.

190. Isung J, Mobarrez F, Nordstrom P, Asberg M, Jokinen J. Low plasma vascular endothelial growth factor (VEGF) associated with completed suicide. World J Biol Psychiatry 2012; 13(6): 468-473.

191. Erhardt S, Lim CK, Linderholm KR, Janelidze S, Lindqvist D, Samuelsson M et al. Connecting inflammation with glutamate agonism in suicidality. Neuropsychopharmacology 2013; 38(5): 743-752.

192. Sublette ME, Galfalvy HC, Fuchs D, Lapidus M, Grunebaum MF, Oquendo MA et al. Plasma kynurenine levels are elevated in suicide attempters with major depressive disorder. Brain, behavior, and immunity 2011; 25(6): 1272-1278. 
193. Pedersen MG, Mortensen PB, Norgaard-Pedersen B, Postolache TT. Toxoplasma gondii infection and self-directed violence in mothers. Archives of general psychiatry 2012; 69(11): 1123-1130.

194. Arling TA, Yolken RH, Lapidus M, Langenberg P, Dickerson FB, Zimmerman SA et al. Toxoplasma gondii antibody titers and history of suicide attempts in patients with recurrent mood disorders. The Journal of nervous and mental disease 2009; 197(12): 905-908.

195. Cook TB, Brenner LA, Cloninger CR, Langenberg P, Igbide A, Giegling I et al. "Latent" infection with Toxoplasma gondii: association with trait aggression and impulsivity in healthy adults. Journal of psychiatric research 2015; 60: 87-94.

196. Flegr J. How and why Toxoplasma makes us crazy. Trends in parasitology 2013; 29(4): 156-163.

197. Okusaga O, Duncan E, Langenberg P, Brundin L, Fuchs D, Groer MW et al. Combined Toxoplasma gondii seropositivity and high blood kynurenine--Linked with nonfatal suicidal self-directed violence in patients with schizophrenia. Journal of psychiatric research 2016; 72: 74-81.

198. Sugden K, Moffitt TE, Pinto L, Poulton R, Williams BS, Caspi A. Is Toxoplasma Gondii Infection Related to Brain and Behavior Impairments in Humans? Evidence from a Population-Representative Birth Cohort. PloS one 2016; 11(2): e0148435.

199. Bay-Richter C, Linderholm KR, Lim CK, Samuelsson M, Traskman-Bendz L, Guillemin GJ et al. A role for inflammatory metabolites as modulators of the glutamate $\mathrm{N}$-methyl-d-aspartate receptor in depression and suicidality. Brain, behavior, and immunity 2014.

200. Pandey GN, Rizavi HS, Ren X, Fareed J, Hoppensteadt DA, Roberts RC et al. Proinflammatory cytokines in the prefrontal cortex of teenage suicide victims. Journal of psychiatric research 2012; 46(1): 57-63.

201. Tonelli LH, Stiller J, Rujescu D, Giegling I, Schneider B, Maurer K et al. Elevated cytokine expression in the orbitofrontal cortex of victims of suicide. Acta Psychiatr Scand 2008; 117(3): 198-206.

202. Ossipov MH, Dussor GO, Porreca F. Central modulation of pain. J Clin Invest 2010; 120(11): 37793787.

203. Russo SJ, Nestler EJ. The brain reward circuitry in mood disorders. Nat Rev Neurosci 2013; 14(9): 609-625. 
204. Lutz PE, Kieffer BL. Opioid receptors: distinct roles in mood disorders. Trends Neurosci 2013; 36(3): 195-206.

205. Escriba PV, Ozaita A, Garcia-Sevilla JA. Increased mRNA expression of alpha2A-adrenoceptors, serotonin receptors and mu-opioid receptors in the brains of suicide victims. Neuropsychopharmacology 2004; 29(8): 1512-1521.

206. Gabilondo AM, Meana JJ, Garcia-Sevilla JA. Increased density of mu-opioid receptors in the postmortem brain of suicide victims. Brain Res 1995; 682(1-2): 245-250.

207. Gross-Isseroff R, Dillon KA, Israeli M, Biegon A. Regionally selective increases in mu opioid receptor density in the brains of suicide victims. Brain Res 1990; 530(2): 312-316.

208. Zubieta JK, Ketter TA, Bueller JA, Xu Y, Kilbourn MR, Young EA et al. Regulation of human affective responses by anterior cingulate and limbic mu-opioid neurotransmission. Arch Gen Psychiatry 2003; 60(11): 1145-1153.

209. Kennedy SE, Koeppe RA, Young EA, Zubieta JK. Dysregulation of endogenous opioid emotion regulation circuitry in major depression in women. Arch Gen Psychiatry 2006; 63(11): 1199-1208.

210. Hurd YL, Herman MM, Hyde TM, Bigelow LB, Weinberger DR, Kleinman JE. Prodynorphin mRNA expression is increased in the patch vs matrix compartment of the caudate nucleus in suicide subjects. Molecular psychiatry 1997; 2(6): 495-500.

211. Hurd YL. Subjects with major depression or bipolar disorder show reduction of prodynorphin mRNA expression in discrete nuclei of the amygdaloid complex. Molecular psychiatry 2002; 7(1): 75-81.

212. Pietrzak RH, Naganawa M, Huang $Y$, Corsi-Travali S, Zheng MQ, Stein MB et al. Association of In Vivo kappa-Opioid Receptor Availability and the Transdiagnostic Dimensional Expression of TraumaRelated Psychopathology. JAMA psychiatry 2014.

213. Lutz PE, Zhou Y, Labbe A, Mechawar N, Turecki G. Decreased expression of nociceptin/orphanin FQ in the dorsal anterior cingulate cortex of suicides. Eur Neuropsychopharmacol 2015; 25(11): 20082014.

214. Eisenberger NI. The pain of social disconnection: examining the shared neural underpinnings of physical and social pain. Nat Rev Neurosci 2012; 13(6): 421-434. 
215. Elman I, Borsook D, Volkow ND. Pain and suicidality: Insights from reward and addiction neuroscience. Prog Neurobiol 2013; 109C: 1-27.

216. Stanley B, Sher L, Wilson S, Ekman R, Huang YY, Mann JJ. Non-suicidal self-injurious behavior, endogenous opioids and monoamine neurotransmitters. J Affect Disord 2010; 124(1-2): 134-140.

217. Kirtley OJ, O'Carroll RE, O'Connor RC. The role of endogenous opioids in non-suicidal selfinjurious behavior: methodological challenges. Neuroscience and biobehavioral reviews 2015; 48: 186189.

218. Sher L, Stanley BH. The role of endogenous opioids in the pathophysiology of self-injurious and suicidal behavior. Arch Suicide Res 2008; 12(4): 299-308.

219. Yovell Y, Bar G, Mashiah M, Baruch Y, Briskman I, Asherov J et al. Ultra-Low-Dose Buprenorphine as a Time-Limited Treatment for Severe Suicidal Ideation: A Randomized Controlled Trial. Am J Psychiatry 2015: appiajp201515040535.

220. Fava M, Memisoglu A, Thase ME, Bodkin JA, Trivedi MH, de Somer M et al. Opioid Modulation With Buprenorphine/Samidorphan as Adjunctive Treatment for Inadequate Response to Antidepressants: A Randomized Double-Blind Placebo-Controlled Trial. Am J Psychiatry 2016: appiajp201515070921.

221. Dwivedi Y, Rizavi HS, Conley RR, Roberts RC, Tamminga CA, Pandey GN. Altered gene expression of brain-derived neurotrophic factor and receptor tyrosine kinase $B$ in postmortem brain of suicide subjects. Archives of general psychiatry 2003; 60(8): 804-815.

222. Banerjee R, Ghosh AK, Ghosh B, Bhattacharyya S, Mondal AC. Decreased mRNA and Protein Expression of BDNF, NGF, and their Receptors in the Hippocampus from Suicide: An Analysis in Human Postmortem Brain. Clin Med Insights Pathol 2013; 6: 1-11.

223. Eisen RB, Perera S, Banfield L, Anglin R, Minuzzi L, Samaan Z. Association between BDNF levels and suicidal behaviour: a systematic review and meta-analysis. Syst Rev 2015; 4: 187.

224. Eisen RB, Perera S, Bawor M, Dennis BB, El-Sheikh W, DeJesus J et al. Exploring the Association between Serum BDNF and Attempted Suicide. Scientific reports 2016; 6: 25229. 
225. Grah M, Mihanovic M, Ruljancic N, Restek-Petrovic B, Molnar S, Jelavic S. Brain-derived neurotrophic factor as a suicide factor in mental disorders. Acta Neuropsychiatr 2014; 26(6): 356-363.

226. Keller S, Sarchiapone M, Zarrilli F, Videtic A, Ferraro A, Carli V et al. Increased BDNF promoter methylation in the Wernicke area of suicide subjects. Archives of general psychiatry 2010; 67(3): 258267.

227. Kang HJ, Kim JM, Lee JY, Kim SY, Bae KY, Kim SW et al. BDNF promoter methylation and suicidal behavior in depressive patients. J Affect Disord 2013; 151(2): 679-685.

228. Roth TL, Lubin FD, Funk AJ, Sweatt JD. Lasting epigenetic influence of early-life adversity on the BDNF gene. Biological psychiatry 2009; 65(9): 760-769.

229. Chen ES, Ernst C, Turecki G. The epigenetic effects of antidepressant treatment on human prefrontal cortex BDNF expression. The international journal of neuropsychopharmacology / official scientific journal of the Collegium Internationale Neuropsychopharmacologicum 2011; 14(3): 427-429.

230. Ernst C, Chen ES, Turecki G. Histone methylation and decreased expression of TrkB.T1 in orbital frontal cortex of suicide completers. Mol Psychiatry 2009; 14(9): 830-832.

231. Maussion G, Yang J, Suderman M, Diallo A, Nagy C, Arnovitz M et al. Functional DNA methylation in a transcript specific 3'UTR region of TrkB associates with suicide. Epigenetics 2014; 9(8): 1061-1070.

232. Maussion G, Yang J, Yerko V, Barker P, Mechawar N, Ernst C et al. Regulation of a Truncated Form of Tropomyosin-Related Kinase B (TrkB) by Hsa-miR-185* in Frontal Cortex of Suicide Completers. PloS one 2012; 7(6): e39301.

233. Perroud N, Courtet P, Vincze I, Jaussent I, Jollant F, Bellivier F et al. Interaction between BDNF Val66Met and childhood trauma on adult's violent suicide attempt. Genes Brain Behav 2008; 7(3): 314322.

234. Sarchiapone M, Carli V, Roy A, lacoviello L, Cuomo C, Latella MC et al. Association of polymorphism (Val66Met) of brain-derived neurotrophic factor with suicide attempts in depressed patients. Neuropsychobiology 2008; 57(3): 139-145.

235. Pregelj P, Nedic G, Paska AV, Zupanc T, Nikolac M, Balazic J et al. The association between brainderived neurotrophic factor polymorphism (BDNF Val66Met) and suicide. J Affect Disord 2011; 128(3): 287-290. 
236. Zarrilli F, Angiolillo A, Castaldo G, Chiariotti L, Keller S, Sacchetti S et al. Brain derived neurotrophic factor (BDNF) genetic polymorphism (Val66Met) in suicide: a study of 512 cases. American journal of medical genetics Part B, Neuropsychiatric genetics : the official publication of the International Society of Psychiatric Genetics 2009; 150B(4): 599-600.

237. Gonzalez-Castro TB, Nicolini H, Lanzagorta N, Lopez-Narvaez L, Genis A, Pool Garcia S et al. The role of brain-derived neurotrophic factor (BDNF) Val66Met genetic polymorphism in bipolar disorder: a case-control study, comorbidities, and meta-analysis of 16,786 subjects. Bipolar Disord 2015; 17(1): 2738.

238. Bresin K, Sima Finy M, Verona E. Childhood emotional environment and self-injurious behaviors: the moderating role of the BDNF Val66Met polymorphism. J Affect Disord 2013; 150(2): 594-600.

239. Schenkel LC, Segal J, Becker JA, Manfro GG, Bianchin MM, Leistner-Segal S. The BDNF Val66Met polymorphism is an independent risk factor for high lethality in suicide attempts of depressed patients. Progress in neuro-psychopharmacology \& biological psychiatry 2010; 34(6): 940-944.

240. Cantarelli Mda G, Tramontina AC, Leite MC, Goncalves CA. Potential neurochemical links between cholesterol and suicidal behavior. Psychiatry research 2014; 220(3): 745-751.

241. Lalovic A, Levy E, Luheshi G, Canetti L, Grenier E, Sequeira A et al. Cholesterol content in brains of suicide completers. The international journal of neuropsychopharmacology / official scientific journal of the Collegium Internationale Neuropsychopharmacologicum 2007; 10(2): 159-166.

242. Jokinen J, Nordstrom AL, Nordstrom P. Cholesterol, CSF 5-HIAA, violence and intent in suicidal men. Psychiatry research 2010; 178(1): 217-219.

243. Lalovic A, Merkens L, Russell L, Arsenault-Lapierre G, Nowaczyk MJ, Porter FD et al. Cholesterol metabolism and suicidality in Smith-Lemli-Opitz syndrome carriers. Am J Psychiatry 2004; 161(11): 21232126.

244. Freemantle E, Mechawar N, Turecki G. Cholesterol and phospholipids in frontal cortex and synaptosomes of suicide completers: relationship with endosomal lipid trafficking genes. Journal of psychiatric research 2013; 47(2): 272-279.

245. Tanskanen A, Vartiainen E, Tuomilehto J, Viinamaki H, Lehtonen J, Puska P. High serum cholesterol and risk of suicide. Am J Psychiatry 2000; 157(4): 648-650. 
246. Shakeri J, Farnia V, Valinia K, Hashemian AH, Bajoghli H, Holsboer-Trachsler E et al. The relationship between lifetime suicide attempts, serum lipid levels, and metabolic syndrome in patients with bipolar disorders. International journal of psychiatry in clinical practice 2015; 19(2): 124-131.

247. Misiak B, Kiejna A, Frydecka D. Higher total cholesterol level is associated with suicidal ideation in first-episode schizophrenia females. Psychiatry research 2015; 226(1): 383-388.

248. Dietschy JM. Central nervous system: cholesterol turnover, brain development and neurodegeneration. Biol Chem 2009; 390(4): 287-293.

249. Koudinov AR, Koudinova NV. Essential role for cholesterol in synaptic plasticity and neuronal degeneration. FASEB J 2001; 15(10): 1858-1860.

250. Roaldset JO, Linaker OM, Bjorkly S. Triglycerides as a biological marker of repeated rehospitalization resulting from deliberate self-harm in acute psychiatry patients: a prospective observational study. BMC Psychiatry 2014; 14: 54.

251. Shin HY, Kang G, Kang HJ, Kim SW, Shin IS, Yoon JS et al. Associations between serum lipid levels and suicidal ideation among Korean older people. J Affect Disord 2016; 189: 192-198.

252. Lalovic A, Klempan T, Sequeira A, Luheshi G, Turecki G. Altered expression of lipid metabolism and immune response genes in the frontal cortex of suicide completers. J Affect Disord 2010; 120(1-3): 24-31.

253. Haghighi F, Galfalvy H, Chen S, Huang YY, Cooper TB, Burke AK et al. DNA methylation perturbations in genes involved in polyunsaturated Fatty Acid biosynthesis associated with depression and suicide risk. Frontiers in neurology 2015; 6: 92.

254. Lalovic A, Levy E, Canetti L, Sequeira A, Montoudis A, Turecki G. Fatty acid composition in postmortem brains of people who completed suicide. J Psychiatry Neurosci 2007; 32(5): 363-370.

255. Evans SJ, Prossin AR, Harrington GJ, Kamali M, Ellingrod VL, Burant CF et al. Fats and factors: lipid profiles associate with personality factors and suicidal history in bipolar subjects. PloS one 2012; 7(1): e29297.

256. Limon A, Mamdani F, Hjelm BE, Vawter MP, Sequeira A. Targets of polyamine dysregulation in major depression and suicide: Activity-dependent feedback, excitability, and neurotransmission. Neuroscience and biobehavioral reviews 2016; 66: 80-91. 
257. Goracke-Postle CJ, Overland AC, Riedl MS, Stone LS, Fairbanks CA. Potassium- and capsaicininduced release of agmatine from spinal nerve terminals. J Neurochem 2007; 102(6): 1738-1748.

258. Wang G, Gorbatyuk OS, Dayanithi G, Ouyang W, Wang J, Milner TA et al. Evidence for endogenous agmatine in hypothalamo-neurohypophysial tract and its modulation on vasopressin release and Ca2+ channels. Brain Res 2002; 932(1-2): 25-36.

259. Hiasa M, Miyaji T, Haruna Y, Takeuchi T, Harada Y, Moriyama S et al. Identification of a mammalian vesicular polyamine transporter. Scientific reports 2014; 4: 6836.

260. Gilad GM, Gilad VH. Overview of the brain polyamine-stress-response: regulation, development, and modulation by lithium and role in cell survival. Cell Mol Neurobiol 2003; 23(4-5): 637-649.

261. Karssen AM, Her S, Li JZ, Patel PD, Meng F, Bunney WE, Jr. et al. Stress-induced changes in primate prefrontal profiles of gene expression. Mol Psychiatry 2007; 12(12): 1089-1102.

262. Shopsin B. The clinical antidepressant effect of exogenous agmatine is not reversed by parachlorophenylalanine: a pilot study. Acta Neuropsychiatr 2013; 25(2): 113-118.

263. Gawali NB, Bulani VD, Chowdhury AA, Deshpande PS, Nagmoti DM, Juvekar AR. Agmatine ameliorates lipopolysaccharide induced depressive-like behaviour in mice by targeting the underlying inflammatory and oxido-nitrosative mediators. Pharmacology, biochemistry, and behavior 2016; 149: 18.

264. Neis VB, Manosso LM, Moretti M, Freitas AE, Daufenbach J, Rodrigues AL. Depressive-like behavior induced by tumor necrosis factor-alpha is abolished by agmatine administration. Behavioural brain research 2014; 261: 336-344.

265. Kotagale NR, Tripathi SJ, Aglawe MM, Chopde CT, Umekar MJ, Taksande BG. Evidences for the agmatine involvement in antidepressant like effect of bupropion in mouse forced swim test. Pharmacology, biochemistry, and behavior 2013; 107: 42-47.

266. Taksande BG, Kotagale NR, Tripathi SJ, Ugale RR, Chopde CT. Antidepressant like effect of selective serotonin reuptake inhibitors involve modulation of imidazoline receptors by agmatine. Neuropharmacology 2009; 57(4): 415-424. 
267. Neis VB, Moretti M, Manosso LM, Lopes MW, Leal RB, Rodrigues AL. Agmatine enhances antidepressant potency of MK-801 and conventional antidepressants in mice. Pharmacology, biochemistry, and behavior 2015; 130: 9-14.

268. Pantazatos SP, Andrews SJ, Dunning-Broadbent J, Pang J, Huang YY, Arango V et al. Isoform-level brain expression profiling of the spermidine/spermine N1-Acetyltransferase1 (SAT1) gene in major depression and suicide. Neurobiology of disease 2015; 79: 123-134.

269. Fiori LM, Turecki G. Implication of the polyamine system in mental disorders. J Psychiatry Neurosci 2008; 33(2): 102-110.

270. Sequeira A, Gwadry FG, Ffrench-Mullen JM, Canetti L, Gingras Y, Casero RA, Jr. et al. Implication of SSAT by gene expression and genetic variation in suicide and major depression. Archives of general psychiatry 2006; 63(1): 35-48.

271. Klempan TA, Rujescu D, Merette C, Himmelman C, Sequeira A, Canetti L et al. Profiling brain expression of the spermidine/spermine N1-acetyltransferase 1 (SAT1) gene in suicide. American journal of medical genetics Part B, Neuropsychiatric genetics : the official publication of the International Society of Psychiatric Genetics 2009; 150B(7): 934-943.

272. Chen GG, Fiori LM, Moquin L, Gratton A, Mamer O, Mechawar N et al. Evidence of altered polyamine concentrations in cerebral cortex of suicide completers. Neuropsychopharmacology 2010; 35(7): 1477-1484.

273. Gross JA, Turecki G. Suicide and the polyamine system. CNS \& neurological disorders drug targets 2013; 12(7): 980-988.

274. Sequeira A, Klempan T, Canetti L, ffrench-Mullen J, Benkelfat C, Rouleau GA et al. Patterns of gene expression in the limbic system of suicides with and without major depression. Mol Psychiatry 2007; 12(7): 640-655.

275. Fiori LM, Mechawar N, Turecki G. Identification and characterization of spermidine/spermine N1-acetyltransferase promoter variants in suicide completers. Biological psychiatry 2009; 66(5): 460467.

276. Pantazatos SP, Huang YY, Rosoklija GB, Dwork AJ, Arango V, Mann JJ. Whole-transcriptome brain expression and exon-usage profiling in major depression and suicide: evidence for altered glial, endothelial and ATPase activity. Mol Psychiatry 2017; 22(5): 760-773. 
277. Lopez JP, Fiori LM, Gross JA, Labonte B, Yerko V, Mechawar N et al. Regulatory role of miRNAs in polyamine gene expression in the prefrontal cortex of depressed suicide completers. The international journal of neuropsychopharmacology / official scientific journal of the Collegium Internationale Neuropsychopharmacologicum 2014; 17(1): 23-32.

278. Fiori LM, Turecki G. Epigenetic regulation of spermidine/spermine N1-acetyltransferase (SAT1) in suicide. Journal of psychiatric research 2011; 45(9): 1229-1235.

279. Gross JA, Fiori LM, Labonte B, Lopez JP, Turecki G. Effects of promoter methylation on increased expression of polyamine biosynthetic genes in suicide. Journal of psychiatric research 2013; 47(4): 513519.

280. Fiori LM, Gross JA, Turecki G. Effects of histone modifications on increased expression of polyamine biosynthetic genes in suicide. The international journal of neuropsychopharmacology / official scientific journal of the Collegium Internationale Neuropsychopharmacologicum 2012; 15(8): 1161-1166.

281. Niculescu AB, Levey DF, Phalen PL, Le-Niculescu H, Dainton HD, Jain $\mathrm{N}$ et al. Understanding and predicting suicidality using a combined genomic and clinical risk assessment approach. Mol Psychiatry 2015; 20(11): 1266-1285.

282. Niculescu AB, Levey D, Le-Niculescu H, Niculescu E, Kurian SM, Salomon D. Psychiatric blood biomarkers: avoiding jumping to premature negative or positive conclusions. Mol Psychiatry 2015; 20(3): 286-288.

283. Le-Niculescu H, Levey DF, Ayalew M, Palmer L, Gavrin LM, Jain N et al. Discovery and validation of blood biomarkers for suicidality. Mol Psychiatry 2013; 18(12): 1249-1264.

284. Raison $\mathrm{CL}$, Miller $\mathrm{AH}$. When not enough is too much: the role of insufficient glucocorticoid signaling in the pathophysiology of stress-related disorders. Am J Psychiatry 2003; 160(9): 1554-1565.

285. Heim C, Shugart M, Craighead WE, Nemeroff CB. Neurobiological and psychiatric consequences of child abuse and neglect. Dev Psychobiol 2010; 52(7): 671-690.

286. Francis D, Diorio J, Liu D, Meaney MJ. Nongenomic transmission across generations of maternal behavior and stress responses in the rat. Science 1999; 286(5442): 1155-1158.

287. Liu D, Diorio J, Tannenbaum B, Caldji C, Francis D, Freedman A et al. Maternal care, hippocampal glucocorticoid receptors, and hypothalamic-pituitary-adrenal responses to stress. Science 1997; 277(5332): 1659-1662. 
288. Weaver IC, Cervoni N, Champagne FA, D'Alessio AC, Sharma S, Seckl JR et al. Epigenetic programming by maternal behavior. Nature neuroscience 2004; 7(8): 847-854.

289. McGowan PO, Sasaki A, D'Alessio AC, Dymov S, Labonte B, Szyf M et al. Epigenetic regulation of the glucocorticoid receptor in human brain associates with childhood abuse. Nature neuroscience 2009; 12(3): 342-348.

290. Turecki G, Meaney MJ. Effects of the Social Environment and Stress on Glucocorticoid Receptor Gene Methylation: A Systematic Review. Biological psychiatry 2014.

291. Brent D, Melhem N, Ferrell R, Emslie G, Wagner KD, Ryan N et al. Association of FKBP5 polymorphisms with suicidal events in the Treatment of Resistant Depression in Adolescents (TORDIA) study. Am J Psychiatry 2010; 167(2): 190-197.

292. Leszczynska-Rodziewicz A, Szczepankiewicz A, Narozna B, Skibinska M, Pawlak J, DmitrzakWeglarz $\mathrm{M}$ et al. Possible association between haplotypes of the FKBP5 gene and suicidal bipolar disorder, but not with melancholic depression and psychotic features, in the course of bipolar disorder. Neuropsychiatric disease and treatment 2014; 10: 243-248.

293. Perroud N, Bondolfi G, Uher R, Gex-Fabry M, Aubry JM, Bertschy G et al. Clinical and genetic correlates of suicidal ideation during antidepressant treatment in a depressed outpatient sample. Pharmacogenomics 2011; 12(3): 365-377.

294. Supriyanto I, Sasada T, Fukutake M, Asano M, Ueno Y, Nagasaki Y et al. Association of FKBP5 gene haplotypes with completed suicide in the Japanese population. Progress in neuropsychopharmacology \& biological psychiatry 2011; 35(1): 252-256.

295. Willour VL, Chen H, Toolan J, Belmonte P, Cutler DJ, Goes FS et al. Family-based association of FKBP5 in bipolar disorder. Mol Psychiatry 2009; 14(3): 261-268.

296. Klengel T, Mehta D, Anacker C, Rex-Haffner M, Pruessner JC, Pariante CM et al. Allele-specific FKBP5 DNA demethylation mediates gene-childhood trauma interactions. Nature neuroscience 2013; 16(1): 33-41.

297. Roy A, Gorodetsky E, Yuan Q, Goldman D, Enoch MA. Interaction of FKBP5, a stress-related gene, with childhood trauma increases the risk for attempting suicide. Neuropsychopharmacology 2010; 35(8): 1674-1683. 
298. Roy A, Hodgkinson CA, Deluca V, Goldman D, Enoch MA. Two HPA axis genes, CRHBP and FKBP5, interact with childhood trauma to increase the risk for suicidal behavior. Journal of psychiatric research 2012; 46(1): 72-79.

299. Lahti J, Ala-Mikkula H, Kajantie E, Haljas K, Eriksson JG, Raikkonen K. Associations Between SelfReported and Objectively Recorded Early Life Stress, FKBP5 Polymorphisms, and Depressive Symptoms in Midlife. Biological psychiatry 2015.

300. Rice L, Waters CE, Eccles J, Garside H, Sommer P, Kay P et al. Identification and functional analysis of SKA2 interaction with the glucocorticoid receptor. J Endocrinol 2008; 198(3): 499-509.

301. Kaminsky Z, Wilcox HC, Eaton WW, Van Eck K, Kilaru V, Jovanovic T et al. Epigenetic and genetic variation at SKA2 predict suicidal behavior and post-traumatic stress disorder. Translational psychiatry 2015; 5: e627.

302. Guintivano J, Brown T, Newcomer A, Jones M, Cox O, Maher BS et al. Identification and replication of a combined epigenetic and genetic biomarker predicting suicide and suicidal behaviors. Am J Psychiatry 2014; 171(12): 1287-1296.

303. He Y, Ecker JR. Non-CG Methylation in the Human Genome. Annu Rev Genomics Hum Genet 2015; 16: 55-77.

304. Kriaucionis $\mathrm{S}$, Heintz $\mathrm{N}$. The nuclear DNA base 5-hydroxymethylcytosine is present in Purkinje neurons and the brain. Science 2009; 324(5929): 929-930.

305. Frye M, Jaffrey SR, Pan T, Rechavi G, Suzuki T. RNA modifications: what have we learned and where are we headed? Nature reviews Genetics 2016; 17(6): 365-372.

306. Nestler EJ. Transgenerational Epigenetic Contributions to Stress Responses: Fact or Fiction? PLoS Biol 2016; 14(3): e1002426.

307. Sweatt JD. Neural Plasticity \& Behavior - Sixty Years of Conceptual Advances. J Neurochem 2016.

308. Ramsahoye BH, Biniszkiewicz D, Lyko F, Clark V, Bird AP, Jaenisch R. Non-CpG methylation is prevalent in embryonic stem cells and may be mediated by DNA methyltransferase 3a. Proceedings of the National Academy of Sciences of the United States of America 2000; 97(10): 5237-5242. 
309. Guo JU, Su Y, Shin JH, Shin J, Li H, Xie B et al. Distribution, recognition and regulation of non-CpG methylation in the adult mammalian brain. Nature neuroscience 2013.

310. Lister R, Mukamel EA, Nery JR, Urich M, Puddifoot CA, Johnson ND et al. Global epigenomic reconfiguration during mammalian brain development. Science 2013; 341(6146): 1237905.

311. Barkat TR, Polley DB, Hensch TK. A critical period for auditory thalamocortical connectivity. Nature neuroscience 2011; 14(9): 1189-1194.

312. Makinodan M, Rosen KM, Ito S, Corfas G. A critical period for social experience-dependent oligodendrocyte maturation and myelination. Science 2012; 337(6100): 1357-1360.

313. Lutz PE, Turecki G. DNA methylation and childhood maltreatment: from animal models to human studies. Neuroscience 2014; 264: 142-156.

314. Jin J, Lian T, Gu C, Yu K, Gao YQ, Su XD. The effects of cytosine methylation on general transcription factors. Scientific reports 2016; 6: 29119.

315. Chen L, Chen K, Lavery LA, Baker SA, Shaw CA, Li W et al. MeCP2 binds to non-CG methylated DNA as neurons mature, influencing transcription and the timing of onset for Rett syndrome. Proceedings of the National Academy of Sciences of the United States of America 2015; 112(17): 55095514.

316. Gabel HW, Kinde B, Stroud H, Gilbert CS, Harmin DA, Kastan NR et al. Disruption of DNAmethylation-dependent long gene repression in Rett syndrome. Nature 2015; 522(7554): 89-93.

317. Luo C, Ecker JR. Epigenetics. Exceptional epigenetics in the brain. Science 2015; 348(6239): 10941095.

318. Tahiliani M, Koh KP, Shen Y, Pastor WA, Bandukwala H, Brudno Y et al. Conversion of 5methylcytosine to 5-hydroxymethylcytosine in mammalian DNA by MLL partner TET1. Science 2009; 324(5929): 930-935.

319. Bachman M, Uribe-Lewis S, Yang X, Williams M, Murrell A, Balasubramanian S. 5Hydroxymethylcytosine is a predominantly stable DNA modification. Nat Chem 2014; 6(12): 1049-1055. 
320. Nestor CE, Ottaviano R, Reddington J, Sproul D, Reinhardt D, Dunican D et al. Tissue type is a major modifier of the 5-hydroxymethylcytosine content of human genes. Genome Res 2012; 22(3): 467477.

321. Booth MJ, Branco MR, Ficz G, Oxley D, Krueger F, Reik W et al. Quantitative Sequencing of 5Methylcytosine and 5-Hydroxymethylcytosine at Single-Base Resolution. Science 2012.

322. Yu M, Hon GC, Szulwach KE, Song CX, Zhang L, Kim A et al. Base-resolution analysis of 5hydroxymethylcytosine in the mammalian genome. Cell 2012; 149(6): 1368-1380.

323. Sun Z, Terragni J, Borgaro JG, Liu Y, Yu L, Guan S et al. High-resolution enzymatic mapping of genomic 5-hydroxymethylcytosine in mouse embryonic stem cells. Cell reports 2013; 3(2): 567-576.

324. Gross JA, Pacis A, Chen GG, Barreiro LB, Ernst C, Turecki G. Characterizing 5hydroxymethylcytosine in human prefrontal cortex at single base resolution. BMC Genomics 2015; 16: 672.

325. Jones PA. Functions of DNA methylation: islands, start sites, gene bodies and beyond. Nature reviews Genetics 2012; 13(7): 484-492.

326. Mellen M, Ayata P, Dewell S, Kriaucionis S, Heintz N. MeCP2 Binds to 5hmC Enriched within Active Genes and Accessible Chromatin in the Nervous System. Cell 2012; 151(7): 1417-1430.

327. Pacis A, Tailleux L, Morin AM, Lambourne J, Maclsaac JL, Yotova V et al. Bacterial infection remodels the DNA methylation landscape of human dendritic cells. Genome Res 2015; 25(12): 18011811.

328. Wu H, D'Alessio AC, Ito S, Wang Z, Cui K, Zhao K et al. Genome-wide analysis of 5hydroxymethylcytosine distribution reveals its dual function in transcriptional regulation in mouse embryonic stem cells. Genes Dev 2011; 25(7): 679-684.

329. Kinde B, Gabel HW, Gilbert CS, Griffith EC, Greenberg ME. Reading the unique DNA methylation landscape of the brain: Non-CpG methylation, hydroxymethylation, and MeCP2. Proceedings of the National Academy of Sciences of the United States of America 2015.

330. Coppieters N, Dieriks BV, Lill C, Faull RL, Curtis MA, Dragunow M. Global changes in DNA methylation and hydroxymethylation in Alzheimer's disease human brain. Neurobiol Aging 2014; 35(6): 1334-1344. 
331. Villar-Menendez I, Blanch M, Tyebji S, Pereira-Veiga T, Albasanz JL, Martin M et al. Increased 5methylcytosine and decreased 5-hydroxymethylcytosine levels are associated with reduced striatal A2AR levels in Huntington's disease. Neuromolecular Med 2013; 15(2): 295-309.

332. Nainar S, Marshall PR, Tyler CR, Spitale RC, Bredy TW. Evolving insights into RNA modifications and their functional diversity in the brain. Nature neuroscience 2016; 19(10): 1292-1298.

333. Schwanhausser B, Busse D, Li N, Dittmar G, Schuchhardt J, Wolf J et al. Global quantification of mammalian gene expression control. Nature 2011; 473(7347): 337-342.

334. Meyer KD, Saletore Y, Zumbo P, Elemento O, Mason CE, Jaffrey SR. Comprehensive analysis of mRNA methylation reveals enrichment in 3' UTRs and near stop codons. Cell 2012; 149(7): 1635-1646.

335. Widagdo J, Zhao QY, Kempen MJ, Tan MC, Ratnu VS, Wei W et al. Experience-Dependent Accumulation of N6-Methyladenosine in the Prefrontal Cortex Is Associated with Memory Processes in Mice. J Neurosci 2016; 36(25): 6771-6777.

336. Du T, Rao S, Wu L, Ye N, Liu Z, Hu H et al. An association study of the m6A genes with major depressive disorder in Chinese Han population. J Affect Disord 2015; 183: 279-286.

337. Samaan Z, Anand SS, Zhang X, Desai D, Rivera M, Pare G et al. The protective effect of the obesity-associated rs9939609 A variant in fat mass- and obesity-associated gene on depression. Mol Psychiatry 2013; 18(12): 1281-1286.

338. Li X, Zhu P, Ma S, Song J, Bai J, Sun F et al. Chemical pulldown reveals dynamic pseudouridylation of the mammalian transcriptome. Nat Chem Biol 2015; 11(8): 592-597.

339. Schwartz S, Bernstein DA, Mumbach MR, Jovanovic M, Herbst RH, Leon-Ricardo BX et al. Transcriptome-wide mapping reveals widespread dynamic-regulated pseudouridylation of ncRNA and mRNA. Cell 2014; 159(1): 148-162.

340. Behm M, Ohman M. RNA Editing: A Contributor to Neuronal Dynamics in the Mammalian Brain. Trends Genet 2016; 32(3): 165-175.

341. Li JB, Church GM. Deciphering the functions and regulation of brain-enriched A-to-I RNA editing. Nature neuroscience 2013; 16(11): 1518-1522. 
342. Karanovic J, Svikovic S, Pantovic M, Durica S, Brajuskovic G, Damjanovic A et al. Joint effect of ADARB1 gene, HTR2C gene and stressful life events on suicide attempt risk in patients with major psychiatric disorders. World J Biol Psychiatry 2015; 16(4): 261-271.

343. Di Narzo AF, Kozlenkov A, Roussos P, Hao K, Hurd Y, Lewis DA et al. A unique gene expression signature associated with serotonin $2 \mathrm{C}$ receptor RNA editing in the prefrontal cortex and altered in suicide. Hum Mol Genet 2014; 23(18): 4801-4813.

344. Bhansali P, Dunning J, Singer SE, David L, Schmauss C. Early life stress alters adult serotonin $2 \mathrm{C}$ receptor pre-mRNA editing and expression of the alpha subunit of the heterotrimeric G-protein $\mathrm{G}$ q. $J$ Neurosci 2007; 27(6): 1467-1473.

345. Briggs JA, Wolvetang EJ, Mattick JS, Rinn JL, Barry G. Mechanisms of Long Non-coding RNAs in Mammalian Nervous System Development, Plasticity, Disease, and Evolution. Neuron 2015; 88(5): 861877.

346. Derrien T, Johnson R, Bussotti G, Tanzer A, Djebali S, Tilgner H et al. The GENCODE v7 catalog of human long noncoding RNAs: analysis of their gene structure, evolution, and expression. Genome Res 2012; 22(9): 1775-1789.

347. Aprea J, Prenninger S, Dori M, Ghosh T, Monasor LS, Wessendorf E et al. Transcriptome sequencing during mouse brain development identifies long non-coding RNAs functionally involved in neurogenic commitment. EMBO J 2013; 32(24): 3145-3160.

348. Spadaro PA, Flavell CR, Widagdo J, Ratnu VS, Troup M, Ragan C et al. Long Noncoding RNADirected Epigenetic Regulation of Gene Expression Is Associated with Anxiety-like Behavior in Mice. Biological psychiatry 2015.

349. Serafini G, Pompili M, Hansen KF, Obrietan K, Dwivedi Y, Shomron N et al. The involvement of microRNAs in major depression, suicidal behavior, and related disorders: a focus on miR-185 and miR491-3p. Cell Mol Neurobiol 2014; 34(1): 17-30.

350. Marques S, Zeisel A, Codeluppi S, van Bruggen D, Mendanha Falcao A, Xiao L et al. Oligodendrocyte heterogeneity in the mouse juvenile and adult central nervous system. Science 2016; 352(6291): 1326-1329.

351. Zeisel A, Munoz-Manchado AB, Codeluppi S, Lonnerberg P, La Manno G, Jureus A et al. Brain structure. Cell types in the mouse cortex and hippocampus revealed by single-cell RNA-seq. Science 2015; 347(6226): 1138-1142. 
352. Mo A, Mukamel EA, Davis FP, Luo C, Henry GL, Picard S et al. Epigenomic Signatures of Neuronal Diversity in the Mammalian Brain. Neuron 2015; 86(6): 1369-1384.

353. Okaty BW, Sugino K, Nelson SB. Cell type-specific transcriptomics in the brain. J Neurosci 2011; 31(19): 6939-6943.

354. Warner-Schmidt JL, Schmidt EF, Marshall JJ, Rubin AJ, Arango-Lievano M, Kaplitt MG et al. Cholinergic interneurons in the nucleus accumbens regulate depression-like behavior. Proceedings of the National Academy of Sciences of the United States of America 2012.

355. Lake BB, Ai R, Kaeser GE, Salathia NS, Yung YC, Liu R et al. Neuronal subtypes and diversity revealed by single-nucleus RNA sequencing of the human brain. Science 2016; 352(6293): 1586-1590.

356. Tagliafierro L, Bonawitz K, Glenn OC, Chiba-Falek O. Gene Expression Analysis of Neurons and Astrocytes Isolated by Laser Capture Microdissection from Frozen Human Brain Tissues. Front Mol Neurosci 2016; 9: 72.

357. Wang C, Schroeder FA, Hooker JM. Visualizing epigenetics: Current advances and advantages in HDAC PET imaging techniques. Neuroscience 2013.

358. Wey HY, Gilbert TM, Zurcher NR, She A, Bhanot A, Taillon BD et al. Insights into neuroepigenetics through human histone deacetylase PET imaging. Sci Transl Med 2016; 8(351): 351ra106.

359. Jinek M, Chylinski K, Fonfara I, Hauer M, Doudna JA, Charpentier E. A programmable dual-RNAguided DNA endonuclease in adaptive bacterial immunity. Science 2012; 337(6096): 816-821.

360. Vojta A, Dobrinic P, Tadic V, Bockor L, Korac P, Julg B et al. Repurposing the CRISPR-Cas9 system for targeted DNA methylation. Nucleic Acids Res 2016.

361. Bernstein DL, Le Lay JE, Ruano EG, Kaestner KH. TALE-mediated epigenetic suppression of CDKN2A increases replication in human fibroblasts. J Clin Invest 2015; 125(5): 1998-2006.

362. Heller EA, Cates HM, Pena CJ, Sun H, Shao N, Feng J et al. Locus-specific epigenetic remodeling controls addiction- and depression-related behaviors. Nature neuroscience 2014; 17(12): 1720-1727. 
363. Liu XS, Wu H, Ji X, Stelzer Y, Wu X, Czauderna S et al. Editing DNA Methylation in the Mammalian Genome. Cell 2016; 167(1): 233-247 e217.

364. Amabile A, Migliara A, Capasso P, Biffi M, Cittaro D, Naldini L et al. Inheritable Silencing of Endogenous Genes by Hit-and-Run Targeted Epigenetic Editing. Cell 2016; 167(1): 219-232 e214.

365. Saraiva J, Nobre RJ, Pereira de Almeida L. Gene therapy for the CNS using AAVs: The impact of systemic delivery by AAV9. J Control Release 2016; 241: 94-109.

366. Mok PL, Pedersen CB, Springate D, Astrup A, Kapur N, Antonsen S et al. Parental Psychiatric Disease and Risks of Attempted Suicide and Violent Criminal Offending in Offspring: A Population-Based Cohort Study. JAMA psychiatry 2016; 73(10): 1015-1022.

367. Stone $\mathrm{M}$, Laughren $\mathrm{T}$, Jones $\mathrm{ML}$, Levenson $\mathrm{M}$, Holland $\mathrm{PC}$, Hughes $\mathrm{A}$ et al. Risk of suicidality in clinical trials of antidepressants in adults: analysis of proprietary data submitted to US Food and Drug Administration. BMJ 2009; 339: b2880.

368. Perlis RH, Purcell S, Fava M, Fagerness J, Rush AJ, Trivedi MH et al. Association between treatment-emergent suicidal ideation with citalopram and polymorphisms near cyclic adenosine monophosphate response element binding protein in the STAR*D study. Archives of general psychiatry 2007; 64(6): 689-697.

369. Klonsky ED, Qiu T, Saffer BY. Recent advances in differentiating suicide attempters from suicide ideators. Curr Opin Psychiatry 2016.

370. Hahn MA, Qiu R, Wu X, Li AX, Zhang H, Wang J et al. Dynamics of 5-hydroxymethylcytosine and chromatin marks in Mammalian neurogenesis. Cell reports 2013; 3(2): 291-300.

371. Kozlenkov A, Wang M, Roussos P, Rudchenko S, Barbu M, Bibikova M et al. Substantial DNA methylation differences between two major neuronal subtypes in human brain. Nucleic Acids Res 2016; 44(6): 2593-2612.

372. Szulwach KE, Li X, Li Y, Song CX, Wu H, Dai Q et al. 5-hmC-mediated epigenetic dynamics during postnatal neurodevelopment and aging. Nature neuroscience 2011; 14(12): 1607-1616.

373. Li X, Wei W, Zhao QY, Widagdo J, Baker-Andresen D, Flavell CR et al. Neocortical Tet3-mediated accumulation of 5-hydroxymethylcytosine promotes rapid behavioral adaptation. Proceedings of the National Academy of Sciences of the United States of America 2014; 111(19): 7120-7125. 
374. Kim DD, Kim TT, Walsh T, Kobayashi Y, Matise TC, Buyske S et al. Widespread RNA editing of embedded alu elements in the human transcriptome. Genome Res 2004; 14(9): 1719-1725.

375. Weissmann D, van der Laan S, Underwood MD, Salvetat N, Cavarec L, Vincent L et al. Regionspecific alterations of A-to-I RNA editing of serotonin $2 c$ receptor in the cortex of suicides with major depression. Translational psychiatry 2016; 6(8): e878. 


\section{Figure legends}

Figure 1. Modelling suicide risk

Several models have been proposed to describe suicide risk. These models seek to describe the factors that lead individuals to transition from non-suicidal self-injury or SI to other forms of SB, including death. Estimated global prevalence rates are indicated in each circle. The Biopsychosocial Model for Suicide Risk describes the various elements that cause clear biological changes that act as distal, mediating, or proximal factors to increase suicide risk. The Motivational-Volitional Model includes the premotivational, motivational, and volitional phases and describes de psychological changes that occur when an individual transitions from non-lethal behaviours to potentially lethal SB. The Acquired Capability Model proposes psychological changes that can lower an individual's aversion to self-harming behaviour and psychologically prepare them to carry out lethal SB.

Figure 2. Biological pathways leading to suicidal behaviour

Many biological factors have been proposed as contributors to suicide risk. ELA, a key contributor to SB, affects stress response systems (HPA axis and polyamine system), which may affect behaviour (anxiety, impulsivity, cognitive ability, social integration, and depressed mood). Changes have also been reported in neurotransmitter and neurotrophic signalling pathways as well as in neuroinflammation and lipid metabolism. These individual factors, as well as their many interactions and overlapping phenotypes (not shown in diagram) work together to modulate the likelihood of engaging in SB.

Figure 3. Brain regions implicated in depression and suicidal behaviour

Several brain regions have been implicated in MDD and SB. Changes to the prefrontal cortex, anterior cingulate cortex, amygdala, hippocampus, raphe nuclei, and locus coeruleus include changes to volume, cellular morphology and density, potential inflammation, altered function, and changes to mRNA and protein expression levels. 


\section{Tables}

Table 1. Main features of epigenetic plasticity: current knowledge and gaps

\begin{tabular}{|c|c|c|c|c|c|c|}
\hline $\begin{array}{l}\text { Molecular } \\
\text { substrate }\end{array}$ & Mark & $\begin{array}{l}\text { Enrichment } \\
\text { in brain }\end{array}$ & $\begin{array}{l}\text { Enrichment in a } \\
\text { specific cell-type }\end{array}$ & Developmental pattern & $\begin{array}{l}\text { Behavioural } \\
\text { experience- } \\
\text { dependent } \\
\text { plasticity }\end{array}$ & $\begin{array}{l}\text { Implication in } \\
\text { depression \& } \\
\text { suicide }\end{array}$ \\
\hline \multirow{3}{*}{$\begin{array}{l}\text { Epigenetic } \\
\text { (DNA) }\end{array}$} & $5 \mathrm{mCG}$ & No & No & No & Yes & Yes \\
\hline & $5 \mathrm{mCH}$ & Yes $^{309}$ & $\begin{array}{l}\text { Yes } \\
\text { neurons } \gg>\text { glia }^{310}\end{array}$ & $\begin{array}{l}\text { Yes } \\
\text { Strong accumulation } \\
\text { during early life }\end{array}$ & ? & $?$ \\
\hline & $5 \mathrm{hmCG}$ & Yes $^{304}$ & $\begin{array}{l}\text { Yes } \\
\text { mature neurons > } \\
\text { progenitors }{ }^{370} \text {; varies } \\
\text { also across neuronal } \\
\text { types }^{326,371}\end{array}$ & $\begin{array}{l}\text { Yes } \\
\text { Genomic pattern formed } \\
\text { in utero }{ }^{310} \text {, with } \\
\text { postnatal dynamics }{ }^{372}\end{array}$ & Yes $^{373}$ & $?$ \\
\hline \multirow{2}{*}{$\begin{array}{l}\text { Epitranscriptomic } \\
\text { (RNA) }\end{array}$} & $6 \mathrm{~mA}$ & $\mathrm{No}^{334}$ & $?$ & Yes $^{334}$ & Yes $^{335}$ & $?$ \\
\hline & A-to-I editing & $\mathrm{No}^{374}$ & $?$ & $?$ & Yes $^{344}$ & Yes $^{80,343,375}$ \\
\hline
\end{tabular}

Supplementary Table 1. Summary of key findings from GWAS Studies

Supplementary Table 1 includes SNP reference sequence ID, official gene name and functional annotation for SNPs identified in GWAS studies with $P$-values below $10^{-5}$. Shaded cells indicate $P$-values below $10^{-6}$. 


\begin{tabular}{|c|c|c|c|c|c|}
\hline Associated gene & $\begin{array}{l}\text { Functional annotation } \\
\text { (determined using https://david.ncifcrf.gov/home.jsp unless otherwise } \\
\text { indicated) }\end{array}$ & $\begin{array}{l}\text { Top SNPs } \\
\text { identified by } \\
\text { authors }\end{array}$ & $\begin{array}{l}\text { Genome- } \\
\text { wide } \\
\text { significance }\end{array}$ & $\begin{array}{l}\text { Reported } \\
P \text {-value }\end{array}$ & Comments \\
\hline A1CF & $\begin{array}{l}\text { APOBEC1 complementation factor(A1CF) } \\
\text { mRNA processing, mRNA localization resulting in posttranscriptional } \\
\text { regulation of gene expression, cytidine to uridine editing, mRNA } \\
\text { modification, protein stabilization } \\
\text { nucleoplasm, cytoplasm, endoplasmic reticulum, apolipoprotein B mRNA } \\
\text { editing enzyme complex } \\
\text { nucleotide binding, RNA binding, double-stranded RNA binding, single- } \\
\text { stranded RNA binding, protein binding }\end{array}$ & rs72787049 48 & No & $1.1 \times 10^{-6}$ & SA, observed in imputed and genotyped SNPs \\
\hline ABI3BP & $\begin{array}{l}\text { ABI family member } 3 \text { binding protein } \\
\text { positive regulation of cell-substrate adhesion, extracellular matrix } \\
\text { organization } \\
\text { interstitial matrix, extracellular space, extracellular matrix } \\
\text { collagen binding, heparin binding, }\end{array}$ & rs $2576377^{41}$ & Yes & $2.55 \times 10^{-8}$ & SA in MDD (Discovery cohort) \\
\hline ADAMTS14 & $\begin{array}{l}\text { ADAM metallopeptidase with thrombospondin type } 1 \text { motif } 14 \\
\text { Inflammatory response } \\
\text { proteolysis, collagen fibril organization, collagen catabolic process } \\
\text { extracellular region, proteinaceous extracellular matrix } \\
\text { metalloendopeptidase activity, zinc ion binding, }\end{array}$ & rs $6480463^{39}$ & No & $1.70 \times 10^{-6}$ & $\begin{array}{l}\text { SA/Suicide vs. Non-attempter live/non-suicide } \\
\text { postmortem }\end{array}$ \\
\hline \multirow[t]{3}{*}{ APOO } & \multirow{3}{*}{$\begin{array}{l}\text { Apolipoprotein } 0 \\
\text { lipid transport, cristae formation } \\
\text { Golgi membrane, extracellular region, extracellular space, mitochondrion, } \\
\text { endoplasmic reticulum membrane, integral component of mitochondrial } \\
\text { inner membrane, very-low-density lipoprotein particle, low-density } \\
\text { lipoprotein particle, high-density lipoprotein particle, MICOS complex } \\
\text { protein binding }\end{array}$} & rs $2520237^{44}$ & No & $9.57 \times 10^{-6}$ & TWSI; genotype $\times$ drug interaction \\
\hline & & rs $2707159^{44}$ & No & $4.50 \times 10^{-6}$ & TWSI; genotype $\times$ drug interaction \\
\hline & & rs $2707159^{44}$ & No & $\begin{array}{l}7.58 \times 10^{-6} \\
\text { in } \\
\text { females; } \\
\text { n.s. in } \\
\text { males }\end{array}$ & $\begin{array}{l}\text { TWSI; genotype } \times \text { drug interaction; potential gender- } \\
\text { dependent effect }\end{array}$ \\
\hline ATL2 (ARL6IP2) ${ }^{*}$ & $\begin{array}{l}\text { Atlastin GTPase } \mathbf{2} \\
\text { ER to Golgi vesicle-mediated transport, endoplasmic reticulum } \\
\text { organization, Golgi organization, protein homooligomerization } \\
\text { endoplasmic reticulum, endoplasmic reticulum membrane, membrane, } \\
\text { integral component of membrane } \\
\text { GTPase activity, protein binding, GTP binding, identical protein binding }\end{array}$ & rs $6737169^{41}$ & No & $8.86 \times 10^{-6}$ & SA in MDD (Discovery cohort) \\
\hline BRINP3 (FAM5C) & $\begin{array}{l}\text { BMP/retinoic acid inducible neural specific } 3 \\
\text { Inflammatory disease } \\
\text { cell cycle arrest, positive regulation of neuron differentiation, negative } \\
\text { regulation of mitotic cell cycle, cellular response to retinoic acid } \\
\text { extracellular region, mitochondrion, endoplasmic reticulum, dendrite, } \\
\text { neuronal cell body }\end{array}$ & rs $17375108^{39}$ & No & $2.66 \times 10^{-6}$ & $\mathrm{Sl}$ in depressed subjects \\
\hline C8orf74 & $\begin{array}{l}\text { Chromosome } 8 \text { open reading frame } 74 \\
\text { protein binding (?) }\end{array}$ & rs7011192 & No & $3.9 \times 10^{-6}$ & Suicide vs. non-SB \\
\hline CAPN13 & $\begin{array}{l}\text { Calpain } 13 \\
\text { proteolysis } \\
\text { intracellular, cytoplasm }\end{array}$ & rs $6548036^{41}$ & No & $7.37 \times 10^{-6}$ & SA in BD (Discovery cohort) \\
\hline
\end{tabular}




\begin{tabular}{|c|c|c|c|c|c|}
\hline & $\begin{array}{l}\text { calcium-dependent cysteine-type endopeptidase activity, calcium ion } \\
\text { binding }\end{array}$ & & & & \\
\hline \multirow[t]{22}{*}{$\mathrm{CCDC7}^{*}$} & \multirow[t]{22}{*}{$\begin{array}{l}\text { Coiled-coil domain containing } 7 \\
\text { Unknown function }\end{array}$} & rs $10740855^{47}$ & No & $7.66 \times 10^{-6}$ & $\begin{array}{l}\text { Suicide behaviour severity in BD; meta-analysis of } \\
\text { three sample sets }\end{array}$ \\
\hline & & rs $10827069^{47}$ & No & $6.52 \times 10^{-6}$ & $\begin{array}{l}\text { Suicide behaviour severity in BD; meta-analysis of } \\
\text { three sample sets }\end{array}$ \\
\hline & & rs $12359568^{47}$ & No & $7.41 \times 10^{-6}$ & $\begin{array}{l}\text { Suicide behaviour severity in BD; meta-analysis of } \\
\text { three sample sets }\end{array}$ \\
\hline & & rs $1831771^{47}$ & No & $7.48 \times 10^{-6}$ & $\begin{array}{l}\text { Suicide behaviour severity in BD; meta-analysis of } \\
\text { three sample sets }\end{array}$ \\
\hline & & rs $1831774^{47}$ & No & $6.97 \times 10^{-6}$ & $\begin{array}{l}\text { Suicide behaviour severity in BD; meta-analysis of } \\
\text { three sample sets }\end{array}$ \\
\hline & & rs $2947080^{47}$ & No & $6.89 \times 10^{-6}$ & $\begin{array}{l}\text { Suicide behaviour severity in } \mathrm{BD} \text {; meta-analysis of } \\
\text { three sample sets }\end{array}$ \\
\hline & & rs $2990980^{47}$ & No & $7.18 \times 10^{-6}$ & $\begin{array}{l}\text { Suicide behaviour severity in } \mathrm{BD} \text {; meta-analysis of } \\
\text { three sample sets }\end{array}$ \\
\hline & & rs $2990984^{47}$ & No & $6.78 \times 10^{-6}$ & $\begin{array}{l}\text { Suicide behaviour severity in BD; meta-analysis of } \\
\text { three sample sets }\end{array}$ \\
\hline & & rs $2990986^{47}$ & No & $7.10 \times 10^{-6}$ & $\begin{array}{l}\text { Suicide behaviour severity in } \mathrm{BD} \text {; meta-analysis of } \\
\text { three sample sets }\end{array}$ \\
\hline & & rs $3006713^{47}$ & No & $5.22 \times 10^{-6}$ & $\begin{array}{l}\text { Suicide behaviour severity in } \mathrm{BD} \text {; meta-analysis of } \\
\text { three sample sets }\end{array}$ \\
\hline & & rs $3006726^{47}$ & No & $8.14 \times 10^{-6}$ & $\begin{array}{l}\text { Suicide behaviour severity in BD; meta-analysis of } \\
\text { three sample sets }\end{array}$ \\
\hline & & rs $7075553^{47}$ & No & $4.45 \times 10^{-6}$ & $\begin{array}{l}\text { Suicide behaviour severity; meta-analysis of three } \\
\text { sample sets }\end{array}$ \\
\hline & & rs $7090007^{47}$ & No & $9.42 \times 10^{-6}$ & $\begin{array}{l}\text { Suicide behaviour severity in BD; meta-analysis of } \\
\text { three sample sets }\end{array}$ \\
\hline & & rs $7910275^{47}$ & No & $7.04 \times 10^{-6}$ & $\begin{array}{l}\text { Suicide behaviour severity in BD; meta-analysis of } \\
\text { three sample sets }\end{array}$ \\
\hline & & rs9338709 & No & $8.12 \times 10^{-6}$ & $\begin{array}{l}\text { Suicide behaviour severity in } \mathrm{BD} \text {; meta-analysis of } \\
\text { three sample sets }\end{array}$ \\
\hline & & rs $944823^{47}$ & No & $6.52 \times 10^{-6}$ & $\begin{array}{l}\text { Suicide behaviour severity in BD; meta-analysis of } \\
\text { three sample sets }\end{array}$ \\
\hline & & rs $1413977^{47}$ & No & $4.58 \times 10^{-6}$ & $\begin{array}{l}\text { Suicide behaviour severity in } \mathrm{BD} \text {; meta-analysis of } \\
\text { three sample sets }\end{array}$ \\
\hline & & rs $1832048^{47}$ & No & $4.34 \times 10^{-6}$ & $\begin{array}{l}\text { Suicide behaviour severity in BD; meta-analysis of } \\
\text { three sample sets }\end{array}$ \\
\hline & & rs $1832048^{47}$ & No & $4.34 \times 10^{-6}$ & $\begin{array}{l}\text { Suicide behaviour severity in } \mathrm{BD} \text {; meta-analysis of } \\
\text { three sample sets }\end{array}$ \\
\hline & & rs $2184486^{47}$ & No & $4.49 \times 10^{-6}$ & $\begin{array}{l}\text { Suicide behaviour severity in BD; meta-analysis of } \\
\text { three sample sets }\end{array}$ \\
\hline & & $\mathrm{rs} 2947059^{47}$ & No & $5.17 \times 10^{-6}$ & $\begin{array}{l}\text { Suicide behaviour severity in BD; meta-analysis of } \\
\text { three sample sets }\end{array}$ \\
\hline & & rs $2992079^{47}$ & No & $6.92 \times 10^{-6}$ & $\begin{array}{l}\text { Suicide behaviour severity in } \mathrm{BD} \text {; meta-analysis of } \\
\text { three sample sets }\end{array}$ \\
\hline
\end{tabular}




\begin{tabular}{|c|c|c|c|c|c|}
\hline & & rs $4749744^{47}$ & No & $5.91 \times 10^{-6}$ & $\begin{array}{l}\text { Suicide behaviour severity in BD; meta-analysis of } \\
\text { three sample sets }\end{array}$ \\
\hline & & rs $7078469^{47}$ & No & $2.43 \times 10^{-6}$ & $\begin{array}{l}\text { Suicide behaviour severity in } \mathrm{BD} \text {; meta-analysis of } \\
\text { three sample sets }\end{array}$ \\
\hline & & rs $7079041^{47}$ & No & $2.35 \times 10^{-6}$ & $\begin{array}{l}\text { Suicide behaviour severity in BD; meta-analysis of } \\
\text { three sample sets }\end{array}$ \\
\hline & & rs708988 ${ }^{47}$ & No & $5.31 \times 10^{-6}$ & $\begin{array}{l}\text { Suicide behaviour severity in BD; meta-analysis of } \\
\text { three sample sets }\end{array}$ \\
\hline & & rs7899433 ${ }^{47}$ & No & $4.15 \times 10^{-6}$ & $\begin{array}{l}\text { Suicide behaviour severity in BD; meta-analysis of } \\
\text { three sample sets }\end{array}$ \\
\hline & & rs7899442 ${ }^{47}$ & No & $4.31 \times 10^{-6}$ & $\begin{array}{l}\text { Suicide behaviour severity in BD; meta-analysis of } \\
\text { three sample sets }\end{array}$ \\
\hline & & rs7899680 & No & $4.18 \times 10^{-6}$ & $\begin{array}{l}\text { Suicide behaviour severity in BD; meta-analysis of } \\
\text { three sample sets }\end{array}$ \\
\hline & & rs $7900825^{47}$ & No & $3.69 \times 10^{-6}$ & $\begin{array}{l}\text { Suicide behaviour severity in } \mathrm{BD} \text {; meta-analysis of } \\
\text { three sample sets }\end{array}$ \\
\hline & & rs7905328 ${ }^{47}$ & No & $6.37 \times 10^{-6}$ & $\begin{array}{l}\text { Suicide behaviour severity in BD; meta-analysis of } \\
\text { three sample sets }\end{array}$ \\
\hline & & rs $7914502^{47}$ & No & $2.89 \times 10^{-6}$ & $\begin{array}{l}\text { Suicide behaviour severity in BD; meta-analysis of } \\
\text { three sample sets }\end{array}$ \\
\hline & & rs9663143 ${ }^{47}$ & No & $6.36 \times 10^{-6}$ & $\begin{array}{l}\text { Suicide behaviour severity in BD; meta-analysis of } \\
\text { three sample sets }\end{array}$ \\
\hline & & rs980117 $7^{47}$ & No & $4.44 \times 10^{-6}$ & $\begin{array}{l}\text { Suicide behaviour severity in BD; meta-analysis of } \\
\text { three sample sets }\end{array}$ \\
\hline & & rs $1333222^{47}$ & No & $7.34 \times 10^{-6}$ & $\begin{array}{l}\text { Suicide behaviour severity in } \mathrm{BD} \text {; meta-analysis of } \\
\text { three sample sets }\end{array}$ \\
\hline DPP10 & Dipeptidyl peptidase like 10 & rs $1374268^{39}$ & No & $5.69 \times 10^{-6}$ & Live SA vs. Depressed non-SA \\
\hline & $\begin{array}{l}\text { Associated with asthma }{ }^{39} \\
\text { proteolysis, protein localization to plasma membrane, positive regulation } \\
\text { of establishment of protein localization to plasma membrane, regulation of } \\
\text { potassium ion transmembrane transport } \\
\text { plasma membrane, membrane, integral component of membrane } \\
\text { serine-type peptidase activity, dipeptidyl-peptidase activity, potassium } \\
\text { channel regulator activity }\end{array}$ & rs $4308128^{39}$ & No & $3.67 \times 10^{-6}$ & Live SA vs. Depressed non-SA \\
\hline EPB41L4A & $\begin{array}{l}\text { Erythrocyte membrane protein band } 4.1 \text { like } 4 \mathrm{~A} \\
\text { actomyosin structure organization } \\
\text { cytoplasm, cytoskeleton, extrinsic component of membrane } \\
\text { structural constituent of cytoskeleton, cytoskeletal protein binding }\end{array}$ & rs13358904 $4^{39}$ & No & $4.96 \times 10^{-6}$ & SI in depressed subjects \\
\hline FBXL18 & $\begin{array}{l}\text { F-box and leucine rich repeat protein } \mathbf{1 8} \\
\text { F-box domain, cyclin-like } \\
\text { Alternative splicing, Complete proteome, Leucine-rich repeat, } \\
\text { Polymorphism, Proteomics identification, Reference proteome, Repeat, Ubl } \\
\text { conjugation pathway }\end{array}$ & rs $4724701^{43}$ & No & $2.00 \times 10^{-6}$ & $\begin{array}{l}\text { TESI vs. non-TESI; Best empiric associations calculated } \\
\text { with Fisher Product Method over both allelic and } \\
\text { genotypic tests }\end{array}$ \\
\hline GDA & $\begin{array}{l}\text { Guanine deaminase } \\
\text { Guanine catabolic process - zinc ion binding - guanine deaminase activity - } \\
\text { hydrolase activity }^{\ddagger}\end{array}$ & rs $11143230^{44}$ & No & $8.28 \times 10^{-7}$ & $\begin{array}{l}\text { TWSI; whole sample; potential effect on females } \\
\text { treated with escitalopram }\end{array}$ \\
\hline
\end{tabular}




\begin{tabular}{|c|c|c|c|c|c|}
\hline & $\begin{array}{l}\text { nucleobase-containing compound metabolic process, guanine catabolic } \\
\text { process, purine nucleotide catabolic process, nervous system development, } \\
\text { guanine metabolic process } \\
\text { intracellular, cytosol, extracellular exosome } \\
\text { zinc ion binding, guanine deaminase activity }\end{array}$ & & & & \\
\hline GFRA1 & $\begin{array}{l}\text { GDNF family receptor alpha } 1 \\
\text { MAPK cascade, cell surface receptor signaling pathway, nervous system } \\
\text { development, glial cell-derived neurotrophic factor receptor signaling } \\
\text { pathway, positive regulation of GTPase activity } \\
\text { intracellular, plasma membrane, extrinsic component of membrane, } \\
\text { anchored component of membrane, extracellular exosome } \\
\text { Ras guanyl-nucleotide exchange factor activity, receptor binding, glial cell- } \\
\text { derived neurotrophic factor receptor activity }\end{array}$ & rs $4751955^{42}$ & No & $\begin{array}{l}7.75 \times 10^{-7} \\
\text { RADIANT } \\
\text { analysis }\end{array}$ & $\begin{array}{l}\text { MDD; quantitative trait analysis (SCAN Suicidality } \\
\text { used to determine } \mathrm{SI} \text { and } \mathrm{SA} \text { ) ; } P=2.84 \times 10^{-5} \text { in meta- } \\
\text { analysis }\end{array}$ \\
\hline \multirow[t]{2}{*}{ IL28RA (IFNLR1) } & \multirow[b]{2}{*}{$\begin{array}{l}\text { Interferon lambda receptor } 1 \\
\text { regulation of immune effector process, regulation of response to biotic } \\
\text { stimulus, negative regulation of cell proliferation, regulation of cell } \\
\text { proliferation, regulation of multi-organism process, regulation of defense } \\
\text { response to virus, regulation of defense response to virus by host } \\
\text { plasma membrane, integral to plasma membrane, integral to membrane, } \\
\text { intrinsic to membrane, intrinsic to plasma membrane, interleukin-28 } \\
\text { receptor complex, receptor complex, plasma membrane part } \\
\text { cytokine receptor activity, cytokine binding }\end{array}$} & rs $10903034^{40}$ & No & $3.02 \times 10^{-6}$ & TESI \\
\hline & & rs $1416834^{40}$ & No & $3.6 \times 10^{-6}$ & TESI \\
\hline Intergenic & Unknown function & rs $10043093^{44}$ & No & $7.59 \times 10^{-6}$ & TWSI; whole sample \\
\hline Intergenic & Unknown function & rs $11852984^{39}$ & No & $1.52 \times 10^{-6}$ & $\begin{array}{l}\text { SA/Suicide vs. Non-attempter live/non-suicide } \\
\text { postmortem }\end{array}$ \\
\hline Intergenic & Unknown function & rs $1219615^{47}$ & No & $6.51 \times 10^{-6}$ & $\begin{array}{l}\text { Suicide behaviour severity in BD; meta-analysis of } \\
\text { three sample sets }\end{array}$ \\
\hline Intergenic $^{*}$ & Unknown function & rs $12751302^{42}$ & No & $\begin{array}{l}1.61 \times 10^{-6} ; \\
\text { RADIANT } \\
\text { analysis }\end{array}$ & MDD; discrete trait: $S A ; P=1.16 \times 10^{-4}$ in meta-analysis \\
\hline Intergenic & Unknown function & rs $1368607^{44}$ & No & $1.76 \times 10^{-6}$ & $\begin{array}{l}\text { TWSI; genotype } \times \text { drug interactions; potential gender } \\
\text { effects }\end{array}$ \\
\hline Intergenic & Unknown function & rs1418811 & No & $1.32 \times 10^{-6}$ & Sl in depressed subjects \\
\hline Intergenic & Unknown function & rs1433412 $2^{44}$ & No & $2.22 \times 10^{-6}$ & $\begin{array}{l}\text { TWSI; genotype } \times \text { drug interactions; potential gender } \\
\text { effects }\end{array}$ \\
\hline Intergenic $^{*}$ & Unknown function & rs $143371100^{47}$ & No & $6.19 \times 10^{-6}$ & $\begin{array}{l}\text { Suicide behaviour severity in BD; meta-analysis of } \\
\text { three sample sets }\end{array}$ \\
\hline Intergenic $^{*}$ & Unknown function & rs1451195 & No & $6.19 \times 10^{-6}$ & $\begin{array}{l}\text { Suicide behaviour severity in BD; meta-analysis of } \\
\text { three sample sets }\end{array}$ \\
\hline Intergenic & Unknown function & rs1473995 ${ }^{44}$ & No & $7.37 \times 10^{-6}$ & TWSI; whole sample \\
\hline Intergenic & Unknown function & rs $17790430^{48}$ & No & $2.5 \times 10^{-6}$ & SA, observed in imputed and genotyped SNPs \\
\hline Intergenic & Unknown function & rs $1879390^{44}$ & No & $6.93 \times 10^{-6}$ & TWSI; escitalopram-treated subjects \\
\hline Intergenic & Unknown function & rs $2419374^{39}$ & No & $9.76 \times 10^{-7}$ & SI in depressed subjects \\
\hline Intergenic & Unknown function & rs $2846685^{44}$ & No & $4.71 \times 10^{-6}$ & $\begin{array}{l}\text { TWSI; genotype } \times \text { drug interactions; potential gender } \\
\text { effects }\end{array}$ \\
\hline Intergenic & Unknown function & rs $2905346^{44}$ & No & $9.47 \times 10^{-6}$ & TWSI; genotype $\times$ drug interactions \\
\hline
\end{tabular}




\begin{tabular}{|c|c|c|c|c|c|}
\hline Intergenic & Unknown function & rs $320461^{39}$ & No & $3.7 \times 10^{-6}$ & Suicide vs. non-SB \\
\hline Intergenic & Unknown function & $\mathrm{rs} 3851150^{47}$ & No & $\begin{array}{l}4.60 \times 10^{-6} \\
\text { meta- } \\
\text { analysis of } \\
3 \text { studies }\end{array}$ & $\begin{array}{l}\text { Suicide behaviour severity in BD; meta-analysis of } \\
\text { three sample sets }\end{array}$ \\
\hline Intergenic & Unknown function & rs $4254432^{44}$ & No & $7.09 \times 10^{-6}$ & TWSI; genotype $\times$ drug interactions \\
\hline Intergenic & Unknown function & rs $6812841^{44}$ & No & $7.70 \times 10^{-6}$ & TWSI; nortriptyline-treated subjects \\
\hline Intergenic & Unknown function & rs7019771 $1^{44}$ & No & $3.81 \times 10^{-6}$ & TWSI; genotype $\times$ gender interaction \\
\hline Intergenic $^{*}$ & Unknown function & rs $720903^{47}$ & No & $4.37 \times 10^{-6}$ & $\begin{array}{l}\text { Suicide behaviour severity in BD; meta-analysis of } \\
\text { three sample sets }\end{array}$ \\
\hline $\begin{array}{l}\text { Intergenic; } \\
\text { closest genes } \\
\text { ACP1, FAM110C, }^{\text {SH3YL1 }}\end{array}$ & 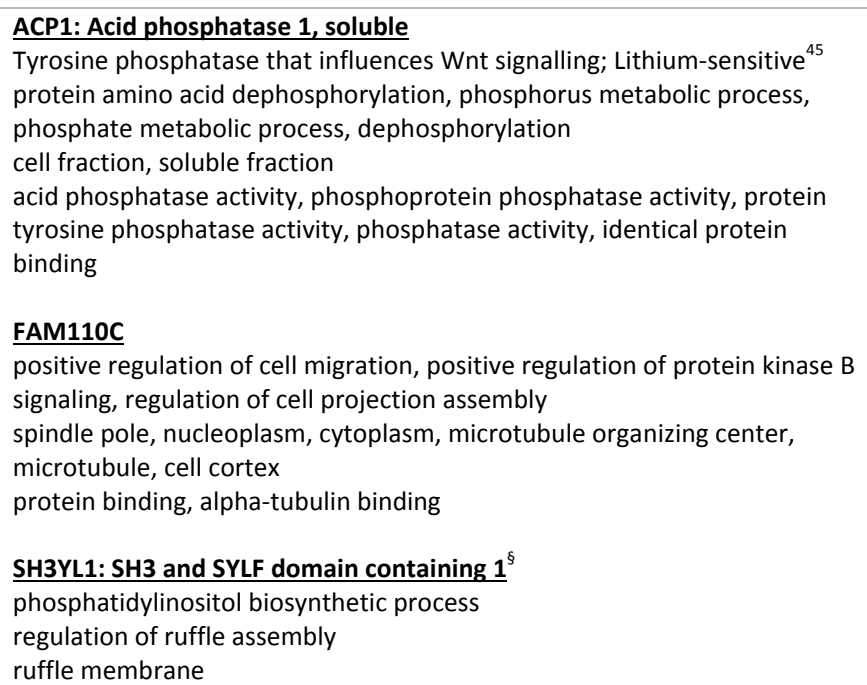 & rs $300774^{45}$ & Threshold & $\begin{array}{l}5.07 \times 10^{-8} ; \\
\text { (combined } \\
\text { analysis of } \\
2 \\
\text { datasets) }\end{array}$ & $\begin{array}{l}\text { SA; Bipolar disorder subjects; } P \text {-value (combined } \\
\text { analysis of } 2 \text { datasets) at threshold of GW } \\
\text { significance; } P \text {-value primary dataset }=1.09 \times 10^{-6}\end{array}$ \\
\hline $\begin{array}{l}\text { Intergenic; } \\
\text { closest gene } \\
\text { ANKRD7 (476kb) }\end{array}$ & $\frac{\text { Ankyrin repeat domain } 7}{\text { male gonad development }}$ & $\mathrm{rs} 6466675^{48}$ & No & $3.0 \times 10^{-6}$ & SA, observed in SNP-by-SNP GWAS \\
\hline $\begin{array}{l}\text { Intergenic; } \\
\text { closest genes } \\
\text { ANXA2 (129kb), } \\
\text { FOXB1 (212kb) }\end{array}$ & $\begin{array}{l}\text { Annexin A2 } \\
\text { cellular growth and signal transduction } 43,5 \\
\text { skeletal system development, angiogenesis, blood vessel development, } \\
\text { vasculature development, body fluid secretion, regulation of blood } \\
\text { coagulation, negative regulation of blood coagulation, extracellular matrix } \\
\text { organization, collagen fibril organization, regulation of response to external } \\
\text { stimulus, fibrinolysis, extracellular structure organization, secretion, blood } \\
\text { vessel morphogenesis, regulation of coagulation, negative regulation of } \\
\text { coagulation, regulation of body fluid levels, negative regulation of } \\
\text { multicellular organismal process } \\
\text { cell fraction, extracellular region, proteinaceous extracellular matrix, } \\
\text { basement membrane, soluble fraction, endosome, early endosome, plasma } \\
\text { membrane, cytoplasmic membrane-bounded vesicle, extracellular matrix, }\end{array}$ & rs $1630535^{43}$ & No & $1.3 \times 10^{-7}$ & $\begin{array}{l}\text { TESI vs. non-TESI; Best empiric associations calculated } \\
\text { with Fisher Product Method over both allelic and } \\
\text { genotypic tests }\end{array}$ \\
\hline
\end{tabular}




\begin{tabular}{|c|c|c|c|c|c|}
\hline & $\begin{array}{l}\text { cytoplasmic vesicle, vesicle, membrane-bounded vesicle, sarcolemma, } \\
\text { melanosome, extracellular matrix part, extracellular region part, } \\
\text { perinuclear region of cytoplasm, pigment granule } \\
\text { enzyme inhibitor activity, phospholipase inhibitor activity, small GTPase } \\
\text { regulator activity, calcium ion binding, phospholipid binding, calcium- } \\
\text { dependent phospholipid binding, phosphatidylinositol-4,5-bisphosphate } \\
\text { binding, cytoskeletal protein binding, lipid binding, Ras GTPase binding, Rab } \\
\text { GTPase binding, enzyme binding, GTPase regulator activity, small GTPase } \\
\text { binding, phosphoinositide binding, ion binding, cation binding, metal ion } \\
\text { binding, GTPase binding, lipase inhibitor activity, nucleoside-triphosphatase } \\
\text { regulator activity }\end{array}$ & & & & \\
\hline $\begin{array}{l}\text { Intergenic; } \\
\text { closest gene } \\
\text { AVPR1A (22kb), } \\
\text { PPM1H (189kb) }\end{array}$ & $\begin{array}{l}\text { AVPR1A: Arginine vasopressin receptor 1A } \\
\text { regulation of systemic arterial blood pressure by vasopressin, maternal } \\
\text { aggressive behavior, positive regulation of systemic arterial blood pressure, } \\
\text { generation of precursor metabolites and energy, G-protein coupled } \\
\text { receptor signaling pathway, activation of phospholipase C activity, positive } \\
\text { regulation of cytosolic calcium ion concentration, negative regulation of } \\
\text { female receptivity, grooming behavior, blood circulation, positive } \\
\text { regulation of cell proliferation, positive regulation of heart rate, positive } \\
\text { regulation of glutamate secretion, myotube differentiation, calcium- } \\
\text { mediated signaling, telencephalon development, positive regulation of cell } \\
\text { growth, positive regulation of prostaglandin biosynthetic process, positive } \\
\text { regulation of cellular pH reduction, cellular response to hormone stimulus, } \\
\text { social behavior, positive regulation of renal sodium excretion, cellular } \\
\text { response to water deprivation, maternal behavior, sperm ejaculation, } \\
\text { penile erection, positive regulation of vasoconstriction, response to } \\
\text { corticosterone, negative regulation of transmission of nerve impulse, } \\
\text { response to peptide } \\
\text { endosome, plasma membrane, integral component of plasma membrane, } \\
\text { integral component of membrane, cytoplasmic vesicle } \\
\text { vasopressin receptor activity, protein kinase C binding, protein binding, } \\
\text { peptide hormone binding, V1A vasopressin receptor binding, peptide } \\
\text { binding } \\
\text { PRM1H: Protein phosphatase, Mg2+/Mn2+ dependent 1H } \\
\text { protein dephosphorylation } \\
\text { nucleus, cytoplasm } \\
\text { phosphoprotein phosphatase activity, protein serine/threonine } \\
\text { phosphatase activity }\end{array}$ & rs $10747978^{48}$ & No & $6.2 \times 10^{-6}$ & SA, observed in SNP-by-SNP GWAS \\
\hline \multirow{2}{*}{$\begin{array}{l}\text { Intergenic; } \\
\text { closest genes } \\
\text { B3GALT5, } \\
\text { C21orf88* }\end{array}$} & \multirow{2}{*}{$\begin{array}{l}\text { Beta-1,3-galactosyltransferase } \mathbf{5} \\
\text { protein amino acid glycosylation, glycoprotein metabolic process, } \\
\text { glycoprotein biosynthetic process, biopolymer glycosylation, glycosylation } \\
\text { endoplasmic reticulum, Golgi apparatus, integral to membrane, intrinsic to } \\
\text { membrane } \\
\text { galactosyltransferase activity, UDP-galactose:beta- } \mathrm{N} \text {-acetylglucosamine } \\
\text { beta-1,3-galactosyltransferase activity, UDP-galactosyltransferase activity, } \\
\text { beta-1,3-galactosyltransferase activity }\end{array}$} & rs $10854398^{41}$ & No & $6.06 \times 10^{-6}$ & $\begin{array}{l}\text { SA in all mood disorders (random-effects meta- } \\
\text { analysis) }\end{array}$ \\
\hline & & rs $8132770^{41}$ & No & $7.15 \times 10^{-6}$ & $\begin{array}{l}\text { SA in all mood disorders (random-effects meta- } \\
\text { analysis) }\end{array}$ \\
\hline
\end{tabular}




\begin{tabular}{|c|c|c|c|c|c|}
\hline & $\frac{\text { C21orf88/B3GALT5 antisense RNA } 1}{\text { Unknown function }}$ & & & & \\
\hline $\begin{array}{l}\text { Intergenic, } \\
\text { closest ELP3 }\end{array}$ & $\begin{array}{l}\text { Elongator acetyltransferase complex subunit } 3 \\
\text { neuron migration, tRNA wobble uridine modification, regulation of } \\
\text { transcription from RNA polymerase II promoter, transcription elongation } \\
\text { from RNA polymerase II promoter, central nervous system development, } \\
\text { positive regulation of cell migration, histone H3 acetylation, histone H4 } \\
\text { acetylation, regulation of protein kinase activity } \\
\text { histone acetyltransferase complex, nucleolus, cytoplasm, transcription } \\
\text { elongation factor complex, Elongator holoenzyme complex } \\
\text { RNA polymerase II core binding, protein binding, N-acetyltransferase } \\
\text { activity, phosphorylase kinase regulator activity, H3 histone } \\
\text { acetyltransferase activity, H4 histone acetyltransferase activity, metal ion } \\
\text { binding, iron-sulfur cluster binding }\end{array}$ & $\begin{array}{l}\text { rs } 4732812^{44} \\
\text { (intergenic) }\end{array}$ & No & $3.35 \times 10^{-6}$ & $\begin{array}{l}\text { TWSI; escitalopram-treated subjects; potential } \\
\text { gender-dependent effects in escitalopram-treated } \\
\text { subjects }\end{array}$ \\
\hline $\begin{array}{l}\text { Intergenic; } \\
\text { closest genes } \\
\text { MIR3977 } \\
\text { (243kb), } \\
\text { ATP6AP1L } \\
\text { (FL41309; } \\
\text { 279kb)* }\end{array}$ & $\begin{array}{l}\text { MIR3977 microRNA } 3977 \\
\text { Unknown function } \\
\text { FU41309/ ATP6AP1L ATPase H+transporting accessory protein } 1 \text { like } \\
\text { ATP hydrolysis coupled proton transport } \\
\text { integral component of membrane, proton-transporting V-type ATPase, V1 } \\
\text { domain } \\
\text { proton-transporting ATP synthase activity, rotational mechanism, proton- } \\
\text { transporting ATPase activity, rotational mechanism }\end{array}$ & rs7720861 ${ }^{48}$ & No & $6.1 \times 10^{-6}$ & SA, observed in SNP-by-SNP GWAS \\
\hline $\begin{array}{l}\text { Intergenic, } \\
\text { closest genes } \\
\text { FU42117 } \\
\text { (C3orf67; } \\
\text { 322kb), FHIT } \\
\text { (377kb) }\end{array}$ & $\begin{array}{l}\text { Chromosome } 3 \text { open reading frame } 67 \\
\text { Unknown function } \\
\frac{\text { FHIT }}{\text { See above }}\end{array}$ & rs $11130703^{41}$ & No & $9.37 \times 10^{-6}$ & SA in BD (Discovery cohort) \\
\hline \multirow[t]{2}{*}{$\begin{array}{l}\text { Intergenic; } \\
\text { closest genes } \\
\text { IL7, STMN2 }\end{array}$} & \multirow{2}{*}{$\begin{array}{l}\text { Interleukin } 7 \\
\text { B and T cell development } \\
\text { T cell lineage commitment, immune response, humoral immune } \\
\text { response, cell-cell signalling, positive regulation of cell proliferation, organ } \\
\text { morphogenesis, regulation of gene expression, positive regulation of B cell } \\
\text { proliferation, negative regulation of apoptotic process, negative regulation } \\
\text { of catalytic activity, bone resorption, positive regulation of T cell } \\
\text { differentiation, positive regulation of organ growth, homeostasis of } \\
\text { number of cells within a tissue, negative regulation of extrinsic apoptotic } \\
\text { signalling pathway in absence of ligand } \\
\text { extracellular region, extracellular space } \\
\text { STMN2: Stathmin } 2 \\
\text { intracellular signaling cascade, neuron differentiation } \\
\text { cell fraction, membrane fraction, soluble fraction, insoluble fraction, } \\
\text { plasma membrane, internal side of plasma membrane, axon, growth cone, }\end{array}$} & rs $10448042^{47}$ & No & $\begin{array}{l}3.65 \times 10^{-6} \\
\text { meta- } \\
\text { analysis of } \\
3 \text { studies }\end{array}$ & $\mathrm{SA}$ in $\mathrm{BD}$; meta-analysis of three sample sets \\
\hline & & rs $10448044^{47}$ & No & $\begin{array}{l}2.81 \times 10^{-6} \\
\text { meta- } \\
\text { analysis of } \\
3 \text { studies }\end{array}$ & $\begin{array}{l}\text { Suicide behaviour severity in BD; meta-analysis of } \\
\text { three sample sets }\end{array}$ \\
\hline
\end{tabular}




\begin{tabular}{|c|c|c|c|c|c|}
\hline & $\begin{array}{l}\text { site of polarized growth, cell projection, neuron projection, plasma } \\
\text { membrane part, perinuclear region of cytoplasm }\end{array}$ & & & & \\
\hline $\begin{array}{l}\text { Intergenic, } \\
\text { closest genes } \\
\text { IRX2, IRX4* }\end{array}$ & $\begin{array}{l}\text { Iroquois homeobox } 2 \\
\text { regulation of transcription, DNA-templated, specification of loop of Henle } \\
\text { identity, proximal/distal pattern formation involved in metanephric } \\
\text { nephron development } \\
\text { nucleus } \\
\text { sequence-specific DNA binding } \\
\text { Iroquois homeobox } 4 \\
\text { regulation of transcription, DNA-templated, heart development, } \\
\text { establishment of organ orientation } \\
\text { nucleus } \\
\text { DNA binding, sequence-specific DNA binding }\end{array}$ & rs924134 $4^{41}$ & No & $6.12 \times 10^{-6}$ & SA in BD (Discovery cohort) \\
\hline \multirow{2}{*}{$\begin{array}{l}\text { Intergenic; } \\
\text { closest genes } \\
\text { KIAA1462, } \\
\text { MTPAP* }\end{array}$} & $\frac{\text { KIAA1462 }}{\text { Unknown function }}$ & rs $2462021^{41}$ & No & $8.30 \times 10^{-6}$ & $\begin{array}{l}\text { SA in all mood disorders (random-effects meta- } \\
\text { analysis) }\end{array}$ \\
\hline & $\begin{array}{l}\text { MTPAP: mitochondrial poly(A) polymerase } \\
\text { transcription, RNA processing, mRNA processing, mRNA metabolic process } \\
\text { mitochondrion } \\
\text { nucleotide binding, nucleoside binding, purine nucleoside binding, RNA } \\
\text { binding, polynucleotide adenylyltransferase activity, ATP binding, } \\
\text { nucleotidyltransferase activity, purine nucleotide binding, adenyl } \\
\text { nucleotide binding, ribonucleotide binding, purine ribonucleotide binding, } \\
\text { adenyl ribonucleotide binding, adenylyltransferase activity }\end{array}$ & rs $1360550^{41}$ & No & $8.95 \times 10^{-6}$ & $\begin{array}{l}\text { SA in all mood disorders (random-effects meta- } \\
\text { analysis) }\end{array}$ \\
\hline \multirow{3}{*}{$\begin{array}{l}\text { Intergenic; } \\
\text { closest genes } \\
\text { LOC100507632/ } \text { LONC00968, } \\
\text { LINCO }^{*} \\
\text { IMPAD1 }^{*}\end{array}$} & \multirow{3}{*}{$\begin{array}{l}\text { LINC00968: long intergenic non-protein coding RNA } 968 \\
\text { Unknown function } \\
\text { IMPAD1: Inositol monophosphatase domain containing } 1 \\
\text { integral to membrane, intrinsic to membrane } \\
\text { magnesium ion binding, inositol or phosphatidylinositol phosphatase } \\
\text { activity, inositol-1(or 4)-monophosphatase activity, phosphatase activity, } \\
\text { ion binding, cation binding, metal ion binding }\end{array}$} & rs $2609990^{47}$ & No & $7.61 \times 10^{-6}$ & $\begin{array}{l}\text { Suicide behaviour severity in BD; meta-analysis of } \\
\text { three sample sets }\end{array}$ \\
\hline & & rs $2582384^{47}$ & No & $8.76 \times 10^{-6}$ & $\begin{array}{l}\text { Suicide behaviour severity in BD; meta-analysis of } \\
\text { three sample sets }\end{array}$ \\
\hline & & rs $2610025^{47}$ & No & $4.61 \times 10^{-6}$ & $\begin{array}{l}\text { Suicide behaviour severity in BD; meta-analysis of } \\
\text { three sample sets }\end{array}$ \\
\hline $\begin{array}{l}\text { Intergenic, } \\
\text { closest gene } \\
\text { LRRIQ3 (LRRC44, } \\
\text { 73kb) }\end{array}$ & $\begin{array}{l}\text { LRRC44/LRRIQ3 leucine rich repeats and IQ motif containing } 3 \\
\text { protein binding }\end{array}$ & rs1417259 ${ }^{41}$ & No & $3.17 \times 10^{-6}$ & SA in MDD (Discovery cohort) \\
\hline $\begin{array}{l}\text { Intergenic; } \\
\text { closest genes } \\
\text { SFRP2 (113kb), } \\
\text { DCHS2 (331kb) }\end{array}$ & $\begin{array}{l}\text { SFRP2: Secreted frizzled related protein } \mathbf{2} \\
\text { patterning of blood vessels, chondrocyte development, outflow tract } \\
\text { morphogenesis, cardiac left ventricle morphogenesis, apoptotic process, G- } \\
\text { protein coupled receptor signaling pathway, cell-cell signaling, multicellular } \\
\text { organism development, response to nutrient, positive regulation of cell } \\
\text { proliferation, negative regulation of cell proliferation, male gonad } \\
\text { development, negative regulation of gene expression, negative regulation } \\
\text { of cardiac muscle cell apoptotic process, negative regulation of epithelial to } \\
\text { mesenchymal transition, positive regulation of endopeptidase activity, } \\
\text { regulation of neuron projection development, Wnt signaling pathway, }\end{array}$ & rs $1993423^{48}$ & No & $3.6 \times 10^{-6}$ & SA, observed in SNP-by-SNP GWAS \\
\hline
\end{tabular}




\begin{tabular}{|c|c|c|c|c|c|}
\hline & 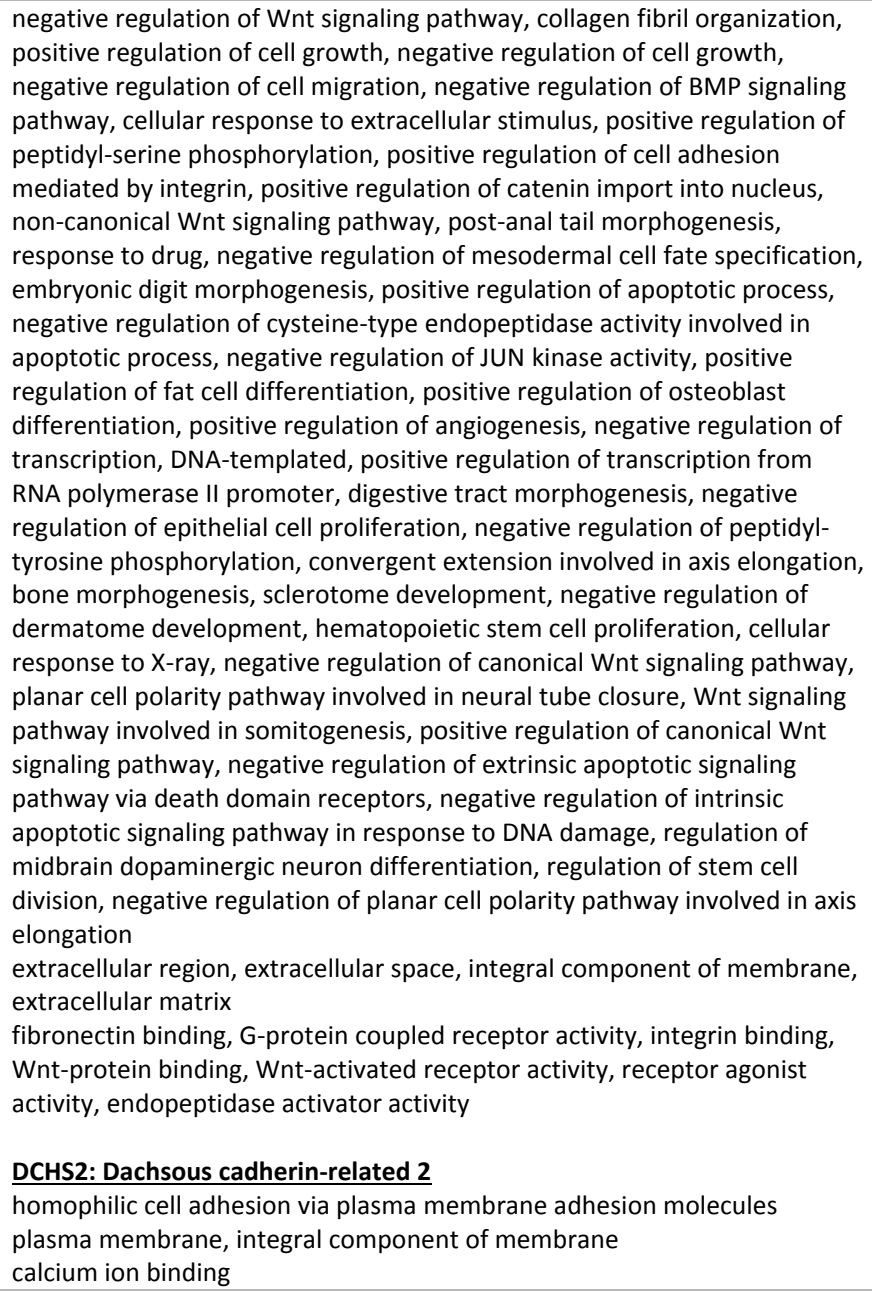 & & & & \\
\hline \multirow{2}{*}{$\begin{array}{l}\text { Intergenic, } \\
\text { closest gene } \\
\text { TBX20* }\end{array}$} & \multirow{2}{*}{$\frac{\text { T-box } 20}{\text { See below }}$} & rs $12538684^{39}$ & No & $6.9 \times 10^{-6}$ & Suicide vs. Non-suicide postmortem \\
\hline & & rs990633 39 & No & $5.6 \times 10^{-6}$ & Suicide vs. Non-suicide postmortem \\
\hline $\begin{array}{l}\text { Intergenic, } \\
\text { closest gene } \\
\text { TMX3 (126kb) }\end{array}$ & $\begin{array}{l}\text { TMX3 } \\
\text { Calcium ion binding and protein disulfide isomerase activity; association } \\
\text { with ADHD and neural development platelet degranulation, protein } \\
\text { folding, peptidyl-cysteine oxidation, response to endoplasmic reticulum } \\
\text { stress, cell redox homeostasis } \\
\text { cell, endoplasmic reticulum membrane, plasma membrane, cell }\end{array}$ & rs7244261 ${ }^{47}$ & No & $\begin{array}{l}4.10 \times 10^{-6} \\
\text { meta- } \\
\text { analysis of } \\
3 \text { studies }\end{array}$ & $\begin{array}{l}\text { Suicide behaviour severity in BD; meta-analysis of } \\
\text { three sample sets }\end{array}$ \\
\hline
\end{tabular}




\begin{tabular}{|c|c|c|c|c|c|}
\hline & $\begin{array}{l}\text { surface, integral component of membrane, platelet alpha granule } \\
\text { membrane }\end{array}$ & & & & \\
\hline $\begin{array}{l}\text { Intergenic, } \\
\text { closest gene } \\
\text { ZFAT (ZNF406, } \\
\text { 390kb) }\end{array}$ & $\begin{array}{l}\text { ZNF406/ZFAT: zinc finger and AT-hook domain containing } \\
\text { hematopoietic progenitor cell differentiation, transcription from RNA } \\
\text { polymerase II promoter, multicellular organism development, positive } \\
\text { regulation of transcription from RNA polymerase II promoter, } \\
\text { spongiotrophoblast layer development } \\
\text { nucleus, cytosol } \\
\text { RNA polymerase II regulatory region sequence-specific DNA binding, } \\
\text { transcriptional activator activity, RNA polymerase II core promoter } \\
\text { proximal region sequence-specific binding, nucleic acid binding, } \\
\text { transcription factor activity, sequence-specific DNA binding, metal ion } \\
\text { binding }\end{array}$ & rs $1457463^{41}$ & No & $8.45 \times 10^{-6}$ & SA in BD (Discovery cohort) \\
\hline KCNIP4 & $\begin{array}{l}\text { Potassium voltage-gated channel interacting protein } 4 \\
\text { cardiac conduction, potassium ion transmembrane transport, protein } \\
\text { localization to plasma membrane, regulation of potassium ion } \\
\text { transmembrane transport } \\
\text { cytoplasm, endoplasmic reticulum, cytosol, plasma membrane, voltage- } \\
\text { gated potassium channel complex } \\
\text { voltage-gated ion channel activity, potassium channel activity, calcium ion } \\
\text { binding, potassium channel regulator activity }\end{array}$ & rs358592 $2^{44}$ & No & $2.5 \times 10^{-6}$ & $\begin{array}{l}\text { TWSI; escitalopram-treated subjects; potential } \\
\text { gender-dependent effect }\end{array}$ \\
\hline $\begin{array}{l}\text { KIAA1244 } \\
\text { (ARFGEF3) }\end{array}$ & $\begin{array}{l}\text { ARFGEF family member } 3 \\
\text { negative regulation of phosphatase activity, regulation of ARF protein } \\
\text { signal transduction, positive regulation of GTPase activity } \\
\text { integral component of membrane, transport vesicle membrane } \\
\text { ARF guanyl-nucleotide exchange factor activity }\end{array}$ & rs $203136^{42}$ & No & $\begin{array}{l}1.74 \times 10^{-7} \\
\text { RADIANT } \\
\text { analysis }\end{array}$ & MDD; discrete trait: $S A ; P=6.24 \times 10^{-5}$ in meta-analysis \\
\hline $\begin{array}{l}\text { KIAA1549L } \\
\text { (C11orf41) }\end{array}$ & $\begin{array}{l}\text { KIAA1549 like } \\
\text { integral component of membrane }\end{array}$ & rs $10437629^{45}$ & No & $\begin{array}{l}3.77 \times 10^{-6} \\
\text { (combined } \\
\text { analysis of } \\
2 \\
\text { datasets) }\end{array}$ & $\begin{array}{l}\text { SA; Bipolar disorder subjects; } P \text {-value primary dataset } \\
=8.56 \times 10^{-5}\end{array}$ \\
\hline \multirow{2}{*}{$\begin{array}{l}\text { MIR548AA1 } \\
\text { MIR548D1 }^{*}\end{array}$} & \multirow{2}{*}{$\begin{array}{l}\text { microRNA 548aa-1 } \\
\text { Unknown function } \\
\text { microRNA 548d-1 } \\
\text { Unknown function }\end{array}$} & rs $6677272^{48}$ & No & $8.6 \times 10^{-7}$ & SA, observed in imputed and genotyped SNPS \\
\hline & & rs6679943 ${ }^{48}$ & No & $8.6 \times 10^{-7}$ & SA, observed in SNP-by-SNP GWAS \\
\hline NCAM1 & $\begin{array}{l}\text { Neural cell adhesion molecule } 1 \\
\text { MAPK cascade, cell adhesion, axon guidance, neuron projection } \\
\text { development, positive regulation of GTPase activity, viral entry into host } \\
\text { cell, regulation of synaptic plasticity, interferon-gamma-mediated signaling } \\
\text { pathway } \\
\text { Golgi membrane, cytoplasm, plasma membrane, external side of plasma } \\
\text { membrane, cell surface, membrane, integral component of membrane, } \\
\text { anchored component of membrane, extracellular exosome } \\
\text { virus receptor activity, Ras guanyl-nucleotide exchange factor activity }\end{array}$ & rs3781878 ${ }^{46}$ & No & $1.98 \times 10^{-6}$ & $\begin{array}{l}\text { SA, Meta-Analysis of RADIANT, GSK-Munich, and } \\
\text { BACCs }\end{array}$ \\
\hline NEBL & $\begin{array}{l}\text { Nebulette } \\
\text { cardiac muscle thin filament assembly } \\
\text { stress fiber, } Z \text { disc, I band, extracellular exosome }\end{array}$ & rs703088 ${ }^{42}$ & No & $\begin{array}{l}9.01 \times 10^{-6} \\
\text { RADIANT } \\
\text { analysis }\end{array}$ & MDD; discrete trait: $S A ; P=5.37 \times 10^{-4}$ in meta-analysis \\
\hline
\end{tabular}




\begin{tabular}{|c|c|c|c|c|c|}
\hline & $\begin{array}{l}\text { protein binding, tropomyosin binding, cytoskeletal protein binding, zinc ion } \\
\text { binding, structural constituent of muscle, filamin binding, actin filament } \\
\text { binding }\end{array}$ & & & & \\
\hline PAPLN & $\begin{array}{l}\text { Papilin, proteoglycan like sulfated glycoprotein } \\
\text { proteolysis, negative regulation of endopeptidase activity } \\
\text { proteinaceous extracellular matrix } \\
\text { metalloendopeptidase activity, serine-type endopeptidase inhibitor } \\
\text { activity, peptidase activity, zinc ion binding }\end{array}$ & rs $11628713^{40}$ & $\begin{array}{l}\text { Experiment- } \\
\text { wide }\end{array}$ & $6.2 \times 10^{-7}$ & TESI \\
\hline PLCB1 & $\begin{array}{l}\text { Phospholipase C beta } 1 \\
\text { Social and communication difficulties in childhood and adolescents } 39 \\
\text { G2/M transition of mitotic cell cycle, signal transduction, G-protein coupled } \\
\text { acetylcholine receptor signaling pathway, glutamate receptor signaling } \\
\text { pathway, Wnt signaling pathway, calcium modulating pathway, brain } \\
\text { development, memory, regulation of G-protein coupled receptor protein } \\
\text { signaling pathway, lipid catabolic process, cerebral cortex development, } \\
\text { positive regulation of interleukin-12 production, intracellular signal } \\
\text { transduction, interleukin-12-mediated signaling pathway, interleukin-15- } \\
\text { mediated signaling pathway, positive regulation of embryonic } \\
\text { development, positive regulation of GTPase activity, inositol phosphate } \\
\text { metabolic process, fat cell differentiation, positive regulation of myoblast } \\
\text { differentiation, negative regulation of transcription, DNA-templated, } \\
\text { positive regulation of transcription, DNA-templated, positive regulation of } \\
\text { JNK cascade, phosphatidylinositol metabolic process, insulin-like growth } \\
\text { factor receptor signaling pathway, positive regulation of developmental } \\
\text { growth, regulation of cell cycle, activation of meiosis involved in egg } \\
\text { activation, interleukin-1-mediated signaling pathway, regulation of } \\
\text { fertilization, positive regulation of G1/S transition of mitotic cell cycle, } \\
\text { positive regulation of acrosome reaction, negative regulation of monocyte } \\
\text { extravasation, positive regulation of CD24 biosynthetic process } \\
\text { nuclear chromatin, nucleus, cytoplasm, cytosol, nuclear speck, nuclear } \\
\text { membrane, myelin sheath, extracellular exosome } \\
\text { phosphatidylinositol phospholipase C activity, signal transducer activity, } \\
\text { GTPase activator activity, calcium ion binding, protein binding, calmodulin } \\
\text { binding, lamin binding, phosphatidylinositol-4,5-bisphosphate binding, } \\
\text { enzyme binding, protein homodimerization activity }\end{array}$ & rs $6055685^{39}$ & No & $8.31 \times 10^{-7}$ & Sl in depressed subjects \\
\hline \multirow[t]{2}{*}{ PRKCE } & \multirow[b]{2}{*}{$\begin{array}{l}\text { Protein kinase C epsilon } \\
\text { macrophage activation involved in immune response, protein } \\
\text { phosphorylation, apoptotic process, cell cycle, cell adhesion, signal } \\
\text { transduction, activation of phospholipase C activity, positive regulation of } \\
\text { epithelial cell migration, positive regulation of fibroblast migration, positive } \\
\text { regulation of cell-substrate adhesion, peptidyl-serine phosphorylation, } \\
\text { platelet activation, positive regulation of actin filament polymerization, } \\
\text { negative regulation of protein ubiquitination, lipopolysaccharide-mediated } \\
\text { signaling pathway, positive regulation of insulin secretion, positive } \\
\text { regulation of synaptic transmission, GABAergic, positive regulation of } \\
\text { cytokinesis, intracellular signal transduction, locomotory exploration } \\
\text { behavior, TRAM-dependent toll-like receptor } 4 \text { signaling pathway, Fc- }\end{array}$} & rs $12373805^{41}$ & No & $9.20 \times 10^{-6}$ & $\begin{array}{l}\text { SA in all mood disorders (random-effects meta- } \\
\text { analysis) }\end{array}$ \\
\hline & & rs $4953249^{42}$ & No & $\begin{array}{l}7.30 \times 10^{-6} ; \\
\text { RADIANT } \\
\text { analysis }\end{array}$ & MDD; discrete trait: $S A ; P=7.15 \times 10^{-3}$ in meta-analysis \\
\hline
\end{tabular}




\begin{tabular}{|c|c|c|c|c|c|}
\hline & $\begin{array}{l}\text { gamma receptor signaling pathway involved in phagocytosis, positive } \\
\text { regulation of I-kappaB kinase/NF-kappaB signaling, response to morphine, } \\
\text { positive regulation of MAPK cascade, regulation of peptidyl-tyrosine } \\
\text { phosphorylation, positive regulation of lipid catabolic process, release of } \\
\text { sequestered calcium ion into cytosol, regulation of release of sequestered } \\
\text { calcium ion into cytosol, cell division, regulation of insulin secretion } \\
\text { involved in cellular response to glucose stimulus, positive regulation of } \\
\text { mucus secretion, cellular response to ethanol, cellular response to } \\
\text { prostaglandin E stimulus, cellular response to hypoxia, positive regulation } \\
\text { of wound healing, positive regulation of receptor activity, negative } \\
\text { regulation of sodium ion transmembrane transporter activity, positive } \\
\text { regulation of cellular glucuronidation } \\
\text { nucleus, cytoplasm, mitochondrion, endoplasmic reticulum, Golgi } \\
\text { apparatus, cytosol, cytoskeleton, plasma membrane, perinuclear region of } \\
\text { cytoplasm, cell periphery } \\
\text { actin monomer binding, protein kinase activity, protein serine/threonine } \\
\text { kinase activity, protein kinase C activity, calcium-independent protein } \\
\text { kinase C activity, signal transducer activity, protein binding, ATP binding, } \\
\text { enzyme activator activity, enzyme binding, receptor activator activity, } \\
\text { ethanol binding, metal ion binding, 14-3-3 protein binding }\end{array}$ & & & & \\
\hline \multirow[t]{2}{*}{ PROM1 } & \multirow[b]{2}{*}{$\begin{array}{l}\text { Prominin } 1 \\
\text { retina layer formation, photoreceptor cell maintenance, retina } \\
\text { morphogenesis in camera-type eye, camera-type eye photoreceptor cell } \\
\text { differentiation, glomerular visceral epithelial cell differentiation, } \\
\text { glomerular parietal epithelial cell differentiation, positive regulation of } \\
\text { nephron tubule epithelial cell differentiation } \\
\text { photoreceptor outer segment, extracellular space, endoplasmic reticulum, } \\
\text { endoplasmic reticulum-Golgi intermediate compartment, plasma } \\
\text { membrane, integral component of plasma membrane, cell surface, integral } \\
\text { component of membrane, apical plasma membrane, microvillus } \\
\text { membrane, vesicle, photoreceptor outer segment membrane, intracellular } \\
\text { membrane-bounded organelle, extracellular exosome } \\
\text { protein binding, actinin binding, cadherin binding }\end{array}$} & rs $17387100^{46}$ & No & $7.98 \times 10^{-7}$ & $\begin{array}{l}\text { SA, Meta-Analysis of RADIANT, GSK-Munich, and } \\
\text { BACCs }\end{array}$ \\
\hline & & rs $17387100^{42}$ & No & $\begin{array}{l}9.53 \times 10^{-6} ; \\
\text { RADIANT } \\
\text { analysis }\end{array}$ & MDD; discrete trait: $S A ; P=4.52 \times 10^{-3}$ in meta-analysis \\
\hline PSME2/RNF31 & $\begin{array}{l}\text { PSME2: proteasome activator subunit } 2 \\
\text { Immunological Disease, inflammatory response } \\
\text { MAPK cascade, protein polyubiquitination, stimulatory C-type lectin } \\
\text { receptor signalling pathway, antigen processing and presentation of } \\
\text { exogenous peptide antigen via MHC class I, TAP-dependent, regulation of } \\
\text { cellular amino acid metabolic process, positive regulation of endopeptidase } \\
\text { activity, anaphase-promoting complex-dependent catabolic process, tumor } \\
\text { necrosis factor-mediated signalling pathway,NIK/NF-kappaB signalling, Fc- } \\
\text { epsilon receptor signalling pathway, proteasome-mediated ubiquitin- } \\
\text { dependent protein catabolic process, regulation of mRNA stability, T cell } \\
\text { receptor signalling pathway, negative regulation of ubiquitin-protein ligase } \\
\text { activity involved in mitotic cell cycle, positive regulation of ubiquitin- } \\
\text { protein ligase activity involved in regulation of mitotic cell cycle } \\
\text { transition, Wnt signalling pathway, planar cell polarity pathway, regulation }\end{array}$ & rs $4575^{39}$ & No & $7.49 \times 10^{-6}$ & $\begin{array}{l}\text { SA/Suicide vs. Non-attempter live/non-suicide } \\
\text { postmortem }\end{array}$ \\
\hline
\end{tabular}




\begin{tabular}{|c|c|c|c|c|c|}
\hline & $\begin{array}{l}\text { of proteasomal protein catabolic process, negative regulation of canonical } \\
\text { Wnt signalling pathway, positive regulation of canonical Wnt signalling } \\
\text { pathway, regulation of G1/S transition of mitotic cell cycle } \\
\text { proteasome complex, nucleoplasm, cytoplasm, cytosol, proteasome } \\
\text { activator complex, membrane, extracellular exosome } \\
\text { protein binding, identical protein binding, endopeptidase activator activity } \\
\text { RNF31: Ring finger protein } \mathbf{3 1} \\
\text { protein polyubiquitination, I-kappaB kinase/NF-kappaB } \\
\text { signalling, regulation of tumor necrosis factor-mediated signalling } \\
\text { pathway, CD40 signalling pathway, positive regulation of I-kappaB } \\
\text { kinase/NF-kappaB signalling, T cell receptor signalling pathway, positive } \\
\text { regulation of NF-kappaB transcription factor activity, protein linear } \\
\text { polyubiquitination, positive regulation of protein targeting to } \\
\text { mitochondrion } \\
\text { cytosol, cytoplasmic side of plasma membrane, CD40 receptor } \\
\text { complex, LUBAC complex } \\
\text { ubiquitin-protein transferase activity, protein binding, zinc ion binding, } \\
\text { ligase activity, ubiquitin protein ligase binding, ubiquitin binding, metal ion } \\
\text { binding }\end{array}$ & & & & \\
\hline RARRES2 & $\begin{array}{l}\text { Retinoic acid receptor responder } \mathbf{2} \\
\text { retinoid metabolic process, in utero embryonic development, positive } \\
\text { regulation of protein phosphorylation, platelet degranulation, chemotaxis, } \\
\text { inflammatory response, positive regulation of macrophage chemotaxis, } \\
\text { positive regulation of fat cell differentiation, embryonic digestive tract } \\
\text { development, brown fat cell differentiation, positive regulation of } \\
\text { chemotaxis, regulation of lipid catabolic process, positive regulation of } \\
\text { glucose import in response to insulin stimulus } \\
\text { extracellular region, extracellular matrix, platelet dense granule lumen, } \\
\text { extracellular exosome } \\
\text { receptor binding, protein binding }\end{array}$ & rs17173608 ${ }^{46}$ & No & $2.41 \times 10^{-7}$ & $\begin{array}{l}\text { SA, Meta-Analysis of RADIANT, GSK-Munich, and } \\
\text { BACCs }\end{array}$ \\
\hline SLC19A2 & $\begin{array}{l}\text { Solute carrier family } 19 \text { member } 2 \\
\text { transport, folic acid transport, thiamine transport, thiamine-containing } \\
\text { compound metabolic process, thiamine transmembrane transport } \\
\text { plasma membrane, integral component of plasma membrane, integral } \\
\text { component of membrane } \\
\text { protein binding, folic acid transporter activity, thiamine transmembrane } \\
\text { transporter activity, thiamine uptake transmembrane transporter activity }\end{array}$ & rs $2072757^{48}$ & No & $2.2 \times 10^{-6}$ & SA, observed in imputed and genotyped SNPs \\
\hline \multirow[t]{2}{*}{ SLC4A4 } & \multirow[b]{2}{*}{$\begin{array}{l}\text { Solute carrier family } 4 \text { member } 4 \\
\text { ion transport, integral component of membrane, transporter activity } \\
\text { transport, sodium ion transport, inorganic anion transport, bicarbonate } \\
\text { transport, sodium ion transmembrane transport, regulation of intracellular } \\
\text { pH, anion transmembrane transport } \\
\text { plasma membrane, integral component of plasma membrane, integral } \\
\text { component of membrane, basolateral plasma membrane, extracellular } \\
\text { exosome } \\
\text { inorganic anion exchanger activity, protein binding, sodium:bicarbonate }\end{array}$} & rs $2602098^{41}$ & No & $8.80 \times 10^{-7}$ & SA in MDD (Discovery cohort) \\
\hline & & rs $7655668^{41}$ & No & $4.16 \times 10^{-6}$ & SA in MDD (Discovery cohort) \\
\hline
\end{tabular}




\begin{tabular}{|c|c|c|c|c|c|}
\hline & symporter activity & & & & \\
\hline \multirow[t]{5}{*}{ SORBS1 } & \multirow{5}{*}{$\begin{array}{l}\text { Sorbin and SH3 domain containing } 1 \\
\text { muscle contraction, actin filament organization, cell adhesion, cell-matrix } \\
\text { adhesion, insulin receptor signaling pathway, positive regulation of signal } \\
\text { transduction, glucose transport, cellular response to insulin stimulus, stress } \\
\text { fiber assembly, positive regulation of glycogen biosynthetic process, } \\
\text { positive regulation of glucose import, positive regulation of lipid } \\
\text { biosynthetic process, focal adhesion assembly, positive regulation of } \\
\text { establishment of protein localization to plasma membrane } \\
\text { stress fiber, nucleus, nucleoplasm, cytoplasm, centrosome, cytosol, plasma } \\
\text { membrane, insulin receptor complex, cell-cell adherens junction, zonula } \\
\text { adherens, cell-substrate adherens junction, focal adhesion, nuclear matrix, } \\
\text { membrane raft } \\
\text { actin binding, SH3/SH2 adaptor activity, insulin receptor binding, protein } \\
\text { binding, cytoskeletal protein binding }\end{array}$} & rs $4918918^{41}$ & No & $3.28 \times 10^{-6}$ & $\begin{array}{l}\text { SA in all mood disorders (random-effects meta- } \\
\text { analysis) }\end{array}$ \\
\hline & & rs7076888 ${ }^{41}$ & No & $8.62 \times 10^{-6}$ & $\begin{array}{l}\text { SA in all mood disorders (random-effects meta- } \\
\text { analysis) }\end{array}$ \\
\hline & & rs $7079293^{41}$ & No & $6.19 \times 10^{-6}$ & $\begin{array}{l}\text { SA in all mood disorders (random-effects meta- } \\
\text { analysis) }\end{array}$ \\
\hline & & rs7900095 ${ }^{41}$ & No & $5.58 \times 10^{-6}$ & $\begin{array}{l}\text { SA in all mood disorders (random-effects meta- } \\
\text { analysis) }\end{array}$ \\
\hline & & rs955760 ${ }^{41}$ & No & $4.87 \times 10^{-6}$ & $\begin{array}{l}\text { SA in all mood disorders (random-effects meta- } \\
\text { analysis) }\end{array}$ \\
\hline SPACA6 ${ }^{*}$ & $\begin{array}{l}\text { Sperm acrosome associated } \mathbf{6} \\
\text { fusion of sperm to egg plasma membrane } \\
\text { integral component of membrane } \\
\text { protein binding }\end{array}$ & rs $12462673^{41}$ & No & $8.85 \times 10^{-6}$ & SA in MDD (Discovery cohort) \\
\hline STK3 & $\begin{array}{l}\text { Serine/threonine kinase } 3 \\
\text { Neuronal cell death } \\
\text { neural tube formation, endocardium development, protein } \\
\text { phosphorylation, apoptotic process, signal transduction, central nervous } \\
\text { system development, negative regulation of cell proliferation, signal } \\
\text { transduction by protein phosphorylation, positive regulation of protein } \\
\text { binding, hippo signaling, intracellular signal transduction, positive } \\
\text { regulation of apoptotic process, positive regulation of fat cell } \\
\text { differentiation, positive regulation of JNK cascade, negative regulation of } \\
\text { organ growth, protein stabilization, positive regulation of sequence-specific } \\
\text { DNA binding transcription factor activity, positive regulation of protein } \\
\text { kinase B signaling, primitive hemopoiesis, cell differentiation involved in } \\
\text { embryonic placenta development, regulation of cell differentiation } \\
\text { involved in embryonic placenta development, positive regulation of protein } \\
\text { serine/threonine kinase activity, negative regulation of canonical Wnt } \\
\text { signaling pathway, hepatocyte apoptotic process, positive regulation of } \\
\text { extrinsic apoptotic signaling pathway via death domain receptors } \\
\text { nucleus, cytoplasm, cytosol, protein complex } \\
\text { magnesium ion binding, protein kinase activity, protein serine/threonine } \\
\text { kinase activity, receptor signaling protein serine/threonine kinase activity, } \\
\text { protein binding, ATP binding, protein serine/threonine kinase activator } \\
\text { activity, protein dimerization activity }\end{array}$ & rs3019286 & No & $8.24 \times 10^{-6}$ & $\begin{array}{l}\text { SA/Suicide vs. Non-attempter live/non-suicide } \\
\text { postmortem }\end{array}$ \\
\hline TBL1XR1 & $\begin{array}{l}\text { Transducin beta like } 1 \text { X-linked receptor } 1 \\
\text { negative regulation of transcription from RNA polymerase II promoter, } \\
\text { response to dietary excess, transcription, DNA-templated, lipid catabolic } \\
\text { process, histone deacetylation, regulation of cAMP metabolic process, } \\
\text { multicellular organism growth, proteasome-mediated ubiquitin-dependent } \\
\text { protein catabolic process, cellular lipid metabolic process, positive }\end{array}$ & rs $1466846^{41}$ & No & $1.98 \times 10^{-6}$ & SA in BD (Discovery cohort) \\
\hline
\end{tabular}




\begin{tabular}{|c|c|c|c|c|c|}
\hline & $\begin{array}{l}\text { regulation of transcription, DNA-templated, positive regulation of } \\
\text { transcription from RNA polymerase II promoter, white fat cell } \\
\text { differentiation, canonical Wnt signaling pathway, fat pad development, } \\
\text { regulation of triglyceride metabolic process } \\
\text { histone deacetylase complex, nucleus, nucleoplasm, spindle microtubule, } \\
\text { integral component of membrane, transcriptional repressor complex } \\
\text { transcription corepressor activity, protein binding, beta-catenin binding, } \\
\text { histone binding, transcription regulatory region DNA binding, protein N- } \\
\text { terminus binding }\end{array}$ & & & & \\
\hline \multirow[t]{6}{*}{ TBX20 } & \multirow{6}{*}{$\begin{array}{l}\text { T-box } 20 \\
\text { Brainstem motor neuron development } \\
\text { Cell Death and Survival }{ }^{39} \\
\text { negative regulation of transcription from RNA polymerase II promoter, } \\
\text { patterning of blood vessels, endoderm formation, neuron migration, heart } \\
\text { looping, embryonic heart tube morphogenesis, outflow tract septum } \\
\text { morphogenesis, tricuspid valve development, aortic valve morphogenesis, } \\
\text { pulmonary valve formation, endocardial cushion morphogenesis, cardiac } \\
\text { chamber formation, cardiac right ventricle morphogenesis, endocardial } \\
\text { cushion formation, cardiac septum development, pericardium } \\
\text { morphogenesis, transcription from RNA polymerase II promoter, muscle } \\
\text { contraction, blood circulation, cell proliferation, dorsal/ventral pattern } \\
\text { formation, negative regulation of SMAD protein complex assembly, visceral } \\
\text { motor neuron differentiation, foramen ovale closure, embryonic heart tube } \\
\text { elongation, negative regulation of transcription, DNA-templated, positive } \\
\text { regulation of transcription from RNA polymerase II promoter, lateral } \\
\text { mesoderm formation, cardiac muscle tissue morphogenesis, positive } \\
\text { regulation of cardiac muscle cell proliferation, atrial septum } \\
\text { morphogenesis, pulmonary vein morphogenesis } \\
\text { nucleus, cytoplasm, } \\
\text { RNA polymerase II regulatory region sequence-specific DNA binding, RNA } \\
\text { polymerase II core promoter proximal region sequence-specific DNA } \\
\text { binding, transcriptional activator activity, RNA polymerase II core promoter } \\
\text { proximal region sequence-specific binding, RNA polymerase II transcription } \\
\text { factor binding, RNA polymerase II activating transcription factor binding, } \\
\text { RNA polymerase II transcription coactivator activity, transcription factor } \\
\text { activity, sequence-specific DNA binding }\end{array}$} & rs17675131 ${ }^{39}$ & No & $1.2 \times 10^{-6}$ & Suicide vs. Non-suicide postmortem \\
\hline & & rs $2109090^{39}$ & No & $2.8 \times 10^{-6}$ & Suicide vs. Non-suicide postmortem \\
\hline & & rs2240994 $4^{39}$ & No & $1.0 \times 10^{-6}$ & Suicide vs. Non-suicide postmortem \\
\hline & & rs $336284^{39}$ & No & $7.56 \times 10^{-6}$ & $\begin{array}{l}\text { SA/Suicide vs. Non-attempter live/non-suicide } \\
\text { postmortem }\end{array}$ \\
\hline & & rs $336284^{39}$ & No & $2.00 \times 10^{-7}$ & Suicide vs. Non-suicide postmortem \\
\hline & & rs $4723402^{39}$ & No & $2.7 \times 10^{-6}$ & Suicide vs. Non-suicide postmortem \\
\hline TMEM132C & $\frac{\text { Transmembrane protein } 132 \mathrm{C}}{\text { integral component of membrane }}$ & rs $7296262^{45}$ & No & $\begin{array}{l}1.09 \times 10^{-6} ; \\
\text { (combined } \\
\text { analysis of } \\
2 \\
\text { datasets) }\end{array}$ & $\begin{array}{l}\text { SA; Bipolar disorder subjects; } P \text {-value primary dataset } \\
=9.08 \times 10^{-6}\end{array}$ \\
\hline
\end{tabular}

"SNPs were mapped back to their corresponding genes using GWAS Central: http://www.gwascentral.org/markers

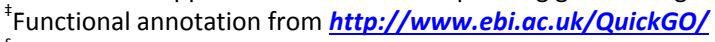

${ }^{5}$ Functional annotation from https://www.ncbi.nlm.nih.gov/gene/

Note: Reference ${ }^{41}$ included multiple tables of SNPs associated with SB that were too voluminous to be included here but can be consulted online at: http://ajp.psychiatryonline.org/doi/suppl/10.1176/appi.ajp.2010.10040541 


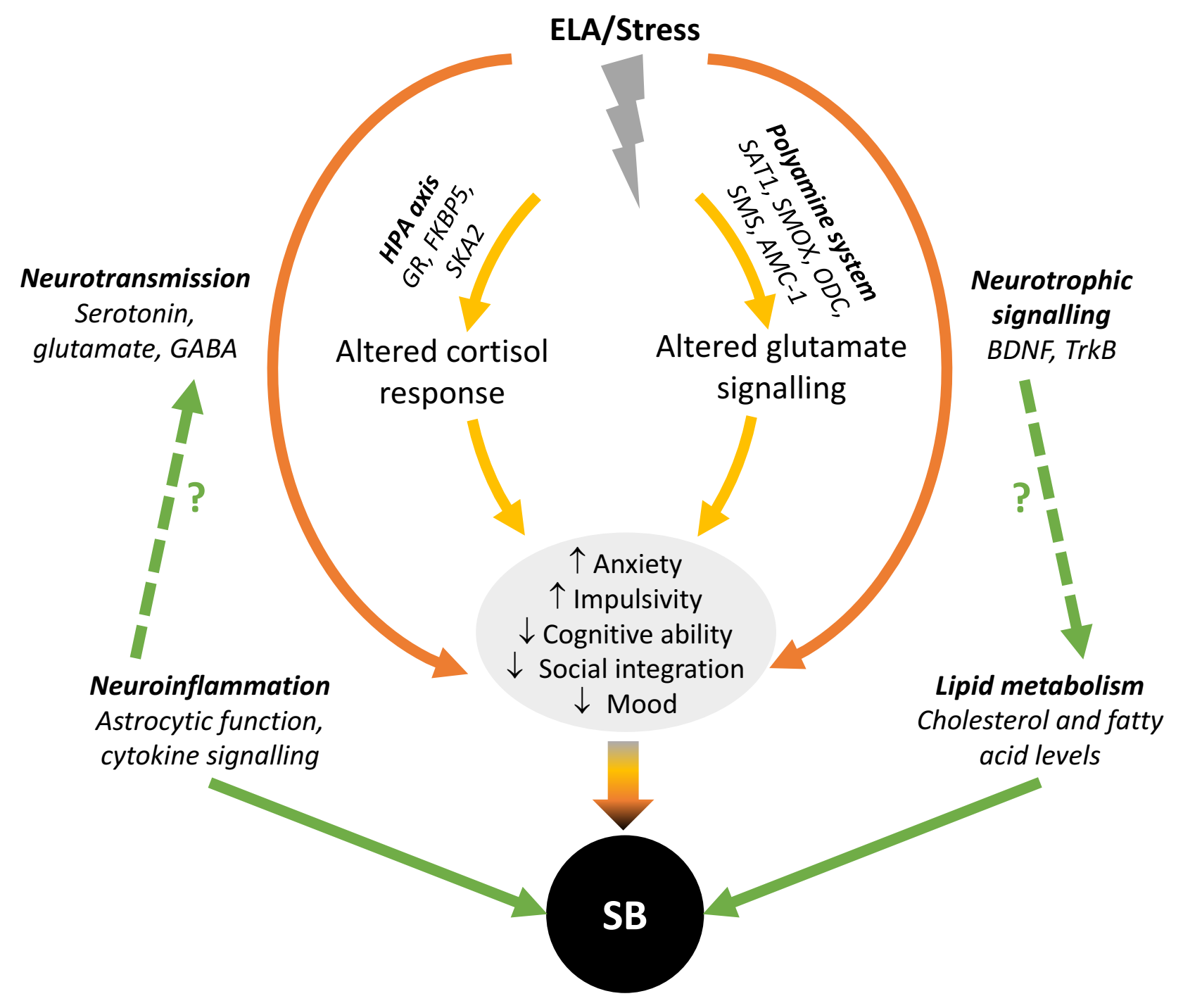

Lutz, Figure 2. Biological pathways to suicidal behaviour 


\section{Prefrontal cortex}

- $\downarrow$ activity

- $\downarrow$ grey matter volume

- Functional $\Delta$ in orbitofrontal cortex

- $\Delta$ cell type densities

- $\uparrow$ macrophage activity

\section{Anterior cingulate cortex}

- $\Delta$ microglial densities

- Astrocyte hypertrophy in dorsal ACC white matter

- Low level inflammation?

- Morphology $\Delta$ of layer VI pyramidal neurons

\section{Amygdala}

- $\uparrow$ cerebral blood flow and glucose metabolism

- $\Delta$ volume

- $\uparrow$ BLA volume

- $\downarrow$ glial densities

- $\Delta$ neuroplasticity

\section{Hippocampus}

- $\downarrow$ volume

- $\downarrow$ neurogenesis in DG

- $\Delta$ granule-cell neuron maturation /survival?

- $\Delta$ CA cellular densities 